University of Louisville

ThinkIR: The University of Louisville's Institutional Repository

\title{
Aboveground-belowground interactions: roles of soil biotic and abiotic factors on switchgrass's (panicum virgatum) growth, defense against herbivory and cell wall chemistry.
}

Binod Basyal

University of Louisville

Follow this and additional works at: https://ir.library.louisville.edu/etd

Part of the Biology Commons, Ecology and Evolutionary Biology Commons, and the Plant Sciences Commons

\section{Recommended Citation}

Basyal, Binod, "Aboveground-belowground interactions: roles of soil biotic and abiotic factors on switchgrass's (panicum virgatum) growth, defense against herbivory and cell wall chemistry." (2020). Electronic Theses and Dissertations. Paper 3394.

https://doi.org/10.18297/etd/3394

This Doctoral Dissertation is brought to you for free and open access by ThinkIR: The University of Louisville's Institutional Repository. It has been accepted for inclusion in Electronic Theses and Dissertations by an authorized administrator of ThinkIR: The University of Louisville's Institutional Repository. This title appears here courtesy of the author, who has retained all other copyrights. For more information, please contact thinkir@louisville.edu. 


\author{
ABOVEGROUND-BELOWGROUND INTERACTIONS: \\ ROLES OF SOIL BIOTIC AND ABIOTIC FACTORS ON SWITCHGRASS'S \\ (PANICUM VIRGATUM) GROWTH, DEFENSE AGAINST HERBIVORY AND CELL \\ WALL CHEMISTRY \\ By \\ Binod Basyal
}

B.Sc. Agriculture, Tribhuvan University, Nepal, 2013

\author{
A Dissertation \\ Submitted to the Faculty of the \\ College of Arts and Sciences of the University of Louisville \\ in Partial Fulfillment of the Requirements \\ for the Degree of \\ Doctor of Philosophy in Biology \\ Department of Biology \\ University of Louisville \\ Louisville, Kentucky
}

May, 2020 



\begin{abstract}
ABOVEGROUND-BELOWGROUND INTERACTIONS:
ROLES OF SOIL BIOTIC AND ABIOTIC FACTORS ON SWITCHGRASS'S

(PANICUM VIRGATUM) GROWTH, DEFENSE AGAINST HERBIVORY AND CELL

WALL CHEMISTRY
\end{abstract}

\author{
By \\ Binod Basyal \\ B.Sc. Agriculture, Tribhuvan University, Nepal, 2013
}

A Dissertation Approved on

April $7^{\text {th }}, 2020$

By the Following Dissertation Committee

\begin{tabular}{c}
\hline $\begin{array}{c}\text { Sarah Emery } \\
\text { (Dissertation Director) }\end{array}$ \\
\hline Stephen P. Yanoviak \\
\hline Mark Running \\
\hline Natalie Christian \\
\hline Karen Stahlheber
\end{tabular}


I dedicate this dissertation to my father

Mr. Lok Prasad Basyal

and my mother

Mrs. Hari Maya Basyal. 


\section{ACKNOWLEDGEMENT}

I thank Brandon Nguyen, Heather Griffith, Sarah Benton and Kaitlyn Goode for helping with soil nematode extraction, preparation of root and ERH slides and maintenance of growth chamber experiments. I thank Matthew Reid, Erin Kinnetz and Andrea Howes with assistance in the biocide field experiment set-up. I also thank Cliff Foster for free cell wall chemistry analysis from the biocide experiment and Katherine Gross for experimental design and implementation. I cannot thank Mark Hammond enough for maintaining the biocide treatments and harvesting switchgrass. Many thanks to Aaron Sexton, Kylea Garces and past and present lab members for their feedback on manuscripts and presentations. I am grateful to have my friends from Frankfort, KY. Thanks to my wife Sajani for being there for me despite being thousands of miles away. Finally, my sincere thanks go to my advisor Dr. Sarah Emery and my committee members for their guidelines, feedback and support. 


\begin{abstract}
ABOVEGROUND-BELOWGROUND INTERACTIONS:

ROLES OF SOIL BIOTIC AND ABIOTIC FACTORS ON SWITCHGRASS'S

(PANICUM VIRGATUM) GROWTH, DEFENSE AGAINST HERBIVORY AND CELL

WALL CHEMISTRY

Binod Basyal

April 07, 2020

Plants constantly interact with their biotic and abiotic soil environments. Most terrestrial plants form beneficial associations with soil microbes such as arbuscular mycorrhizal (AM) fungi, which are widely known for their ability to transfer soil phosphorus and nitrogen to the host plants. They help plants tolerate drought stress and improve plant defense against herbivores such as plant-parasitic nematodes (PPNs).

This dissertation investigates the role of AM fungi on switchgrass's (Panicum virgatum) growth, cell wall chemistry, and defense against PPNs using a combination of growth chamber and field studies. Switchgrass is a native warm-season species which is gaining traction as candidate lignocellulosic biofuel crop. It forms a tight association with AM fungi, and PPNs like Pratylenchus penetrans can become a potential threat when the plant is grown in monocultures. My first study was a growth chamber experiment where I manipulated the absence and presence of an AM fungal species to examine its effects on switchgrass's growth and defense against Pratylenchus penetrans under drought conditions. I found that AM fungi increased root biomass under drought conditions and
\end{abstract}


reduced the abundance of the PPN in plant roots by about $66 \%$. I followed this study with a field experiment where I manipulated soil fungi and nematodes by applying biocides. I found that the application of biocides resulted in an altered monomeric composition of lignin in switchgrass. My final study was a growth chamber study where I looked at the effects of AM fungi on switchgrass along a drought intensity gradient. Overall, I found that AM fungi provided maximum benefit to the plants in extreme drought and the benefit declined with increasing moisture indicating that the functioning of AM fungi can span a mutualism-parasitism continuum. Mycorrhizal plants also had increased root biomass, cellulose, and hemicellulose regardless of drought treatment.

These studies provide evidence that AM fungi can have wide ranging effects on switchgrass growth and physiology and these effects can sometimes be altered by the soil abiotic environments. Overall, my results suggest that plant-AM fungal symbiosis can become ever more important in the face of climate change. 
TABLE OF CONTENTS

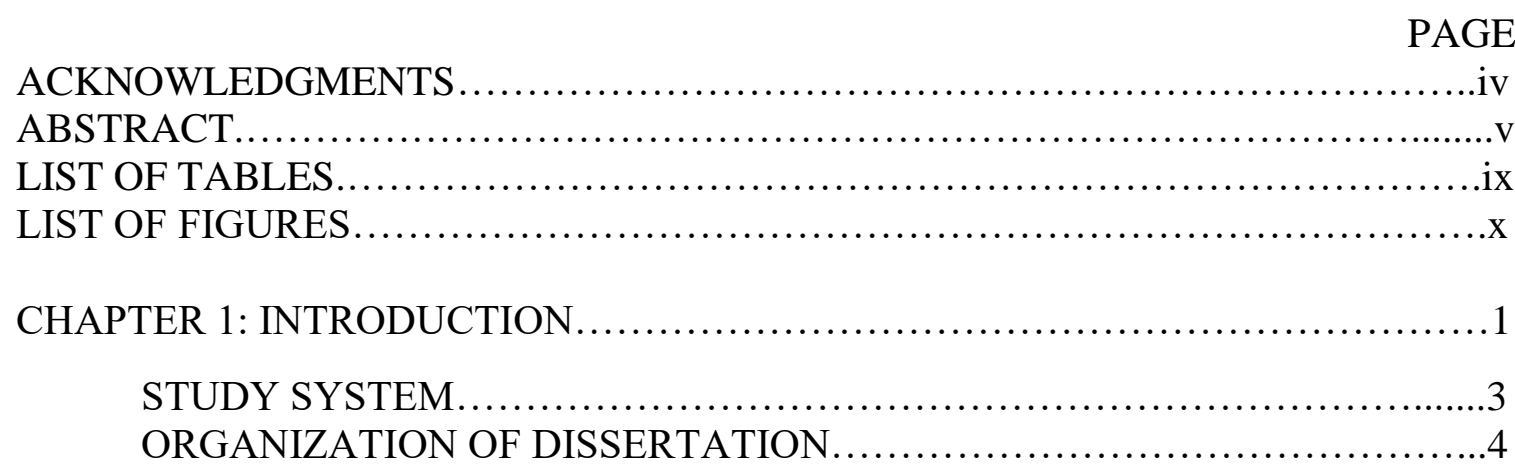

CHAPTER II: ARBUSCULAR MYCORRHIZAL FUNGI AND DROUGHT ALTER PLANT RESPONSES TO NEMATODE ROOT HERBIVORY ......................6

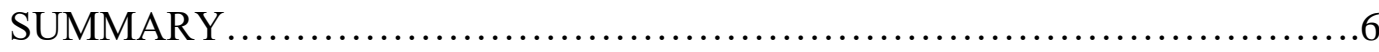

INTRODUCTION .......................................................

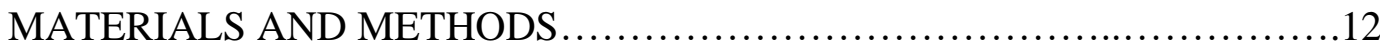

RESULTS............................................................. 16

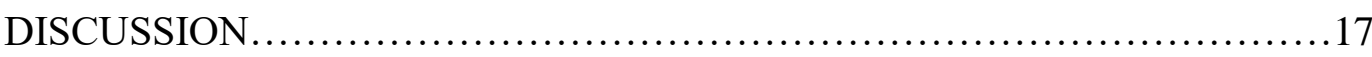

CHAPTER III: DO SOIL BIOTIC AND ABIOTIC FACTORS HAVE DIFFERENT EFFECTS ON ABOVEGROUND AND BELOWGROUND LIGNIN 1 COMPOSITION

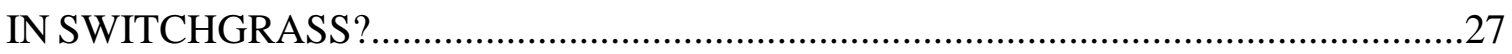

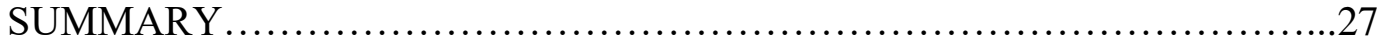

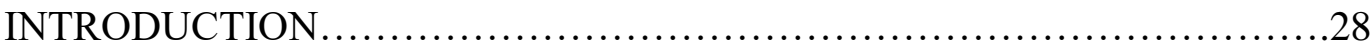

MATERIALS AND METHODS ............................................ 31

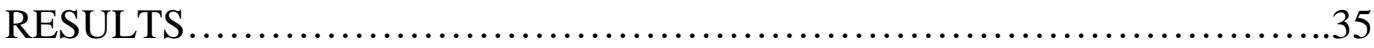

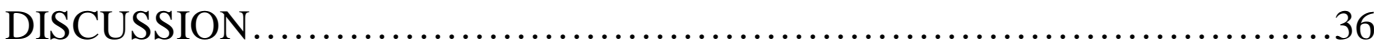

CHAPTER IV: ARBUSCULAR MYCORRHIZAL FUNGI BENEFIT SWITCHGRASS GROWTH ACROSS A SOIL MOISTURE GRADIENT ...........................48

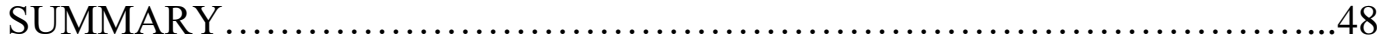

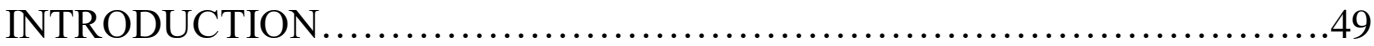

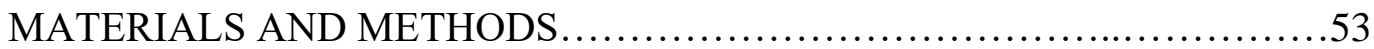

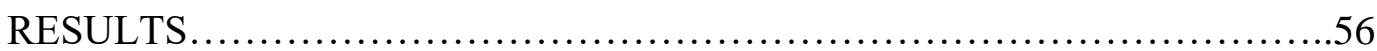

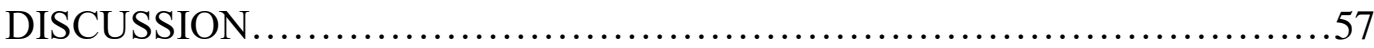

CHAPTER V: SUMMARY AND FUTURE DIRECTIONS..........................71 
SUMMARY .......................................................... 71

FUTURE DIRECTIONS .................................................. 72

REFERENCES.............................................................. 75

APPENDIX I............................................................ 91

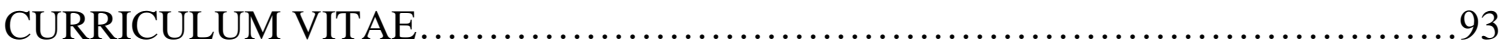




\section{LIST OF TABLES}

TABLE

PAGE

1. ANOVA Table: Effects of switchgrass cultivar, AM fungi and drought on above-and belowground responses under PPN herbivory stress...........................22

2. GLM Table: Effects of biocides and fertilizer on lignin content and composition of switchgrass leaf tissues...................................................... 41

3. GLM Table: Effects of biocides and fertilizer on lignin content and composition of switchgrass stem tissues..................................................... 42

4. GLM Table: Effects of biocides and fertilizer on lignin content and composition of switchgrass root tissues...................................................... 43

5. GLM Table: Effects of AM fungi and drought on switchgrass aboveground measures............................................................................ 62

6. GLM Table: Effects of AM fungi and drought on switchgrass belowground

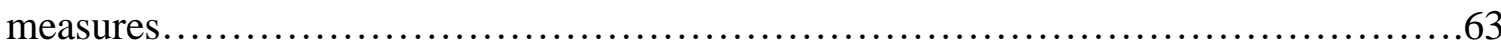

7. GLM Table: Effects of AM fungi and drought on switchgrass cell wall chemistry...64 


\section{LIST OF FIGURES}

FIGURE

PAGE

1. Switchgrass growth in response to AM fungi and drought under overall belowground

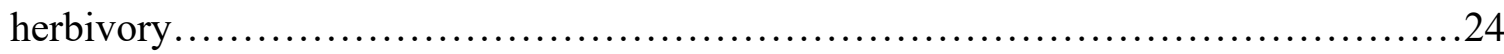

2. (a) AM fungi effects on PPN root abundance (b) Relationship between PPN abundance

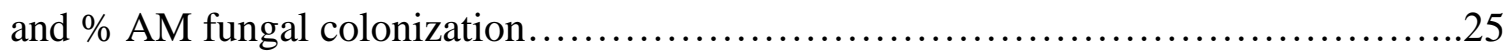

3. Root biomass of PPN-exposed switchgrass in response to AM fungi and drought......26

4. Effects of biocides and $\mathrm{N}$ fertilizer on switchgrass leaf p-hydroxyphenyl unit.......45

5. Stem lignin responses of switchgrass to biocides and $\mathrm{N}$ fertilizer.................46

6. Root lignin responses of switchgrass to biocides and $\mathrm{N}$ fertilizer................47

7. Theoretical framework for plant-mycorrhizal symbiosis along moisture gradient.....66

8. Switchgrass aboveground growth responses to AM fungi along moisture gradient...67

9. Switchgrass belowground growth responses to AM fungi along moisture gradient....68

10. $\mathrm{R} / \mathrm{S}$ ratio of switchgrass in response to AM fungi along moisture gradient..........69

11. Switchgrass belowground cell wall chemistry response along moisture gradient.....70

12. KBS LTER Cellulosic Biofuel Diversity Experiment plot layout..................91 
13. Map of KBS LTER site... 


\section{CHAPTER I}

\section{INTRODUCTION}

Arbuscular mycorrhizal fungi form one of the most ancient and ubiquitous symbioses with terrestrial vascular plants (Smith and Read 2010). They penetrate the cortical cells of roots of vascular plants and establish a symbiosis whereby they derive carbon from their host plants (Willis et al. 2013). They are widely known for supplying their host plants with soil nutrients such as phosphorus $(\mathrm{P})$ and nitrogen $(\mathrm{N})$ in return for the photosynthetic carbon (Allen 1991). With the use of their extra-radical hyphae (ERH) that extends beyond plant root tissues, AM fungi directly help plants cope with drought stress, which is arguably the most important abiotic stress for plants (Wu et al. 2013). They can indirectly improve a plant's tolerance to drought by affecting morphophysiological responses such as growth, root/shoot ratio, phenology, photorespiration and production, and allocation of osmoregulatory chemicals (Boomsma and Vyn 2008). Symbiosis with AM fungi becomes particularly important to plants as the frequency and severity of drought is predicted to increase in the near future (Carnicer et al. 2011; Meehl and Tebaldi 2004).

Recently, the ability of AM fungi to induce resistance in plants against a host of biotic stressors like herbivores and pathogens is also being recognized (Schouteden et al. 2015; Song et al. 2015). AM fungi can provide bio-protection to plants against pests and pathogens via mechanisms such as competition for infection sites and host 
photosynthates, enhanced nutrition, activation of plant chemical defense responses, and altering root exudation among others (Harrier and Watson 2004; Schouteden et al. 2015). Climate change is predicted to adversely affect plant health by a multitude of mechanisms such as accelerated evolution of pathogens and pests, shortened incubation periods, or magnified abiotic stresses like drought, making plants vulnerable to diseases and pests (Carnicer et al. 2011; Pautasso et al. 2012; Scherm 2004). Thus, it becomes important to understand the role of root symbionts like AM fungi on alleviating biotic and abiotic stresses such as herbivory and drought on plants.

Perennial $\mathrm{C}_{4}$ grasses like Panicum virgatum (switchgrass) form a strong obligate symbiosis with AM fungi (Clark et al. 1999; Emery et al. 2017). This grass is native to the United States except California and the Pacific Northwest (USDA 2006). The United States Energy Independence and Security Act of 2007 mandates the production of 16 billion gallons of biofuel from lignocellulosic bioenergy crops by 2022 (Congress 2007) and switchgrass is currently a leading candidate crop for lignocellulosic biofuel production (Bouton 2007; Miller et al. 2016). Apart from its economic benefits, switchgrass can be grown in nutrient poor soil where it is known to provide a range of ecological benefits such as carbon sequestration, reduction in soil erosion, and habitat for wildlife (Hartman et al. 2011). About 35 switchgrass cultivars have been documented and released (Mitchell et al. 2014). Switchgrass biomass is valued for its high cellulose content, which can be efficiently converted to ethanol through biochemical digestion. However, other aspects of switchgrass chemistry, including cell wall lignin abundance, can interfere with biochemical conversion efficiency (Zeng et al. 2014) 
Interactions with AM fungi can alter a host plant's tissue chemistry with potential ecological and economic consequences (Schweiger and Müller 2015). They can alter a plant's direct and indirect defense metabolites such as lignin or herbivore-induced sesquiterpene (Baslam et al. 2014; Fontana et al. 2009; Goicoechea-Preboste et al. 2010). Such AM fungal effects on plant cell wall chemistry, especially lignin, have been contentious as they seem to vary in their magnitude and direction (Baslam et al. 2014; Lee et al. 2012). It is important to understand how AM fungi alter cell wall chemistry in order for growers to make the best decisions for bioenergy production.

Additionally, AM fungi-plant symbioses can be influenced by abiotic conditions. The functioning of plant-mycorrhizal symbiosis occurs along a continuum of mutualism to parasitism which is largely dictated by the abiotic environment (Johnson et al. 1997). The host response to the symbiosis can be positive or negative as measured by increase/decrease in growth and fitness. For example, AM fungi are considered parasitic when the cost of maintaining the mycobiont exceeds the benefits they provide to their host (Neuhauser and Fargione 2004). Demonstration of putative mycorrhizal parasitism has been done almost exclusively in the context of low light or high soil nutrients, and much less is known how plants respond to AM colonization along a drought intensity gradient (Johnson et al. 1997; Pischl and Barber 2017; Sendek et al. 2019).

\section{STUDY SYSTEM}

I conducted my dissertation research using a combination of growth chamber and field experiments. The first and the third experiments (Ch. 2, 4) were conducted in environmentally controlled growth chambers at the Department of Biology, University of Louisville. These experiments were conducted to understand specific plant responses to 
AM fungi and drought while being able to control confounding factors. The second experiment (Ch. 3) was conducted in the field at the W.K. Kellogg Biological Station Long Term Ecological Research (KBS LTER) site in Michigan USA (42 $23047^{\prime \prime} \mathrm{N}$, $\left.85^{\circ} 22026^{\prime \prime} \mathrm{W}\right)$ (Appendix I Supplemental Fig. 12) as part of the Cellulosic Biofuels

Diversity Experiment (Appendix I Supplemental Fig. 13). This was established in 2008 to compare 12 different biofuel cropping systems, including two cultivars of switchgrass ("Cave-in-Rock" and "Southlow"; each planted at a rate of $3.9 \mathrm{~kg}$ ha-1) grown at two levels of 103 fertilization (56 kg N ha-1 and unfertilized).

\section{ORGANIZATION OF DISSERTATION}

In this dissertation, I investigated the effects of AM fungi and drought on growth, cell wall chemistry, and defense against belowground plant parasitic nematodes (PPN). I addressed basic ecological questions concerning belowground plant symbioses and climate change in an applied agricultural context. I used a combination of growth and field studies to examine the role of AM fungi on switchgrass protection against biotic and abiotic stresses, via altered resource allocations to growth and altered cell wall chemistry.

Chapter two of this dissertation focuses on switchgrass growth and herbivory defense response under drought stress. I analyzed both aboveground and belowground plant growth measures in the presence of belowground PPN herbivory at both wellwatered and drought conditions in a factorial growth chamber experiment where I manipulated the presence or absence of AM fungi and drought. I further investigated whether AM fungi ameliorates both of the stresses. The results indicated that AM fungi mitigate the adverse effects of multiple co-occurring stresses by providing bio-protection and belowground growth benefits. 
In chapter three I evaluated the effects of nitrogen fertilization and removal of soil organisms on lignin quantity and quality of switchgrass. I removed soil nematodes and fungi by applying biocides in a long-term $\mathrm{N}$ fertilization field experiment. Overall, I found an increase in lignin content due to $\mathrm{N}$ fertilization. Both $\mathrm{N}$ fertilization and biocides altered monomeric composition of lignin, and soil organisms had similar magnitudes of effects to $\mathrm{N}$ fertilization for some measures of lignin composition exhibiting their roles in affecting biomass quality of switchgrass.

The fourth chapter aims to examine switchgrass responses to AM fungal colonization along a drought intensity gradient. I manipulated the presence or absence of AM fungi, while a drought treatment was as maintained as a continuum from very low soil moisture to very high soil moisture. I analyzed biomass, root architecture, and cell wall chemistry of switchgrass and found that AM fungi provide maximum growth benefit in low soil moisture and the benefits decline with increasing soil moisture. I also found an increased level of root cellulose and hemicellulose in response to mycorrhizal colonization. The results indicate that AM fungi can become parasitic when soil resources like water are in abundance. These results validate the mutualism-parasitism continuum theory of plant-mycorrhizal functioning along a drought gradient.

The fifth chapter presents the main summary and conclusion of the dissertation. It also focuses on future research directions and identifies potential opportunities in the field of plant-AM fungal interactions. 


\title{
CHAPTER II
}

\section{ARBUSCULAR MYCORRHIZAL FUNGI AND DROUGHT ALTER PLANT RESPONSES TO NEMATODE ROOT HERBIVORY}

\begin{abstract}
SUMMARY
Herbivory and drought are among the most important biotic and abiotic stresses to plants, and when acting simultaneously, they can negatively impact plant health. Plantassociated soil symbionts such as arbuscular mycorrhizal (AM) fungi can alleviate the stress of herbivory and drought, but few studies have examined the potential benefits of AM fungi to plants undergoing both stresses at once. This study measured growth of Panicum virgatum (switchgrass) when exposed to belowground herbivory under both well-watered and drought conditions to determine whether AM fungi can help ameliorate both stresses. I used a factorial growth chamber experiment in which two cultivars of switchgrass were inoculated with Pratelynchus penetrans, a common migratory root endo-parasitic nematode, and then grown with or without the presence of AM fungi. Half of all pots were also subjected to drought, to test the impacts of AM fungi on plants exposed to multiple stresses. Plants grown with AM fungi had $66 \%$ fewer nematodes in their roots, independent of drought conditions Plants grown with AM fungi under drought and herbivore stress had $32 \%$ higher dry root biomass than those grown
\end{abstract}


without AM fungi. The results of this study show that AM fungi remain beneficial or neutral to switchgrass plants experiencing root herbivory, even when plants are also drought stressed. The results support the importance of the switchgrass plant-AM fungi mutualism for mitigating multiple co-occurring stresses, and warrant further research on the role of AM fungi for plant protection against simultaneous biotic and abiotic stresses in both agricultural and natural settings.

\section{INTRODUCTION}

Plants are continuously exposed to many biotic and abiotic stresses, and herbivory and drought are among the most important and ubiquitous sources of stress for plants. Vertebrate and invertebrate herbivores exert biotic stress on plants by feeding on various parts of the plants at different stages, mechanically damaging the plants both above- and belowground (Crawley 1989; Gill 1992). Drought is one of the most prevalent abiotic stress factors to affect plants (Blum \& Jordan 1985), and its frequency and severity are expected to be more pronounced as climate changes (Carnicer et al. 2011; Meehl \& Tebaldi 2004). The effects of drought are widely observed in agriculture, where crop production is often drastically reduced (Wilhite 2000), and drought also negatively affects several other measures of plant performance including germination (Kaya et al. 2006), vegetative growth (Manickavelu et al. 2006) and photosynthetic ability (Chaves et al. 2009).

Herbivory may have harmful, neutral, or beneficial effects on the fitness of host plants (Whitham 1991), with responses varying according to the biotic and abiotic conditions plants experience (Maschinski \& Whitham 1989). In particular, Maschinski and Whitham's (1989) compensatory continuum model predicts that a plant's potential to 
tolerate herbivory should be greater in an environment with higher resource availability. Water is an important limiting resource and its availability can affect plant growth responses to herbivory. For example, aboveground compensatory growth was positively correlated with moisture availability in a study examining cinnabar moth feeding on tansy ragwort done by Cox and McEvoy (1983). Similarly, Stone and Bacon (1994) found a significant correlation between moisture stress and \% leaf area lost to insect herbivory for Eucalyptus trees.

Soil moisture also can affect belowground herbivory. Drying of soil can directly affect belowground herbivores by inducing them to move downward in the soil column where moisture is usually retained, and so access to plant roots decreases (Villani \& Wright 1988). Drought stress can also result in the increased production of secondary metabolites in roots (Zhang et al. 2008) that can adversely affect belowground herbivores. (Gutbrodt et al. 2011). Alternatively, drought can increase the susceptibility of plants to belowground herbivores which feed on host tissues that are directly involved in the acquisition of limited resources (Wise \& Abrahamson 2005). For example, drought resulted in low concentrations of aboveground defense compounds in severely stressed garlic mustard plants (Gutbrodt et al. 2011) consequently increasing the plant's susceptibility to herbivory.

However, plants can form associations with symbiotic organisms, such as mycorrhizal fungi, endophytic fungi, or rhizobacteria, which can ameliorate effects of drought and herbivory on plant growth (Rosumek et al. 2009; Schutzendubel \& Polle 2002; Yang et al. 2009). While the benefits of symbioses have been shown in a wide variety of plant responses to herbivory and drought individually (e.g., Bennett \& Bever 
2007; Marulanda et al. 2009), the benefits of these symbiotic associations when plants have multiple co-occurring stresses is less straightforward and may even shift symbiotic associations from mutualistic to parasitic (Leung \& Poulin 2008).

Arbuscular mycorrhizal (AM) fungi are one group of symbionts that can help plants tolerate both biotic and abiotic stresses by associating with the roots of vascular plants (Pozo \& Azcón-Aguilar 2007; Singh et al. 2011). They can be particularly helpful in protecting plants against plant parasitic nematodes (PPN), an important group of herbivores that are usually belowground parasites and can be major pests in agricultural systems (Schouteden et al. 2015). Arbuscular mycorrhizal fungi provide host plant protection against PPN through induction of systemic resistance, direct competition for root space, enhanced tolerance, and altered rhizosphere interactions (Elsen et al. 2008; Hao et al. 2012; Jung et al. 2012; Schouteden et al. 2015). AM fungi can also compensate for PPN damages by increasing root branching (Elsen et al. 2003).

AM fungi can help plants in alleviation of drought stress through direct absorption of water by hyphae (Ruiz-Lozano \& Azcón 1995) where hyphae can access tightly bound water in dry soil which would otherwise be inaccessible to plants (Franson et al. 1991). Arbuscular mycorrhizal fungi can also alter root morphology, root hydraulic conductivity, hormonal signaling, stomatal conductance, and transpiration (Augé et al. 1986; Duan et al. 1996; Kothari et al. 1990; Price et al. 1989; Safir et al. 1971). In doing so, AM fungi may consequently lower the permanent wilting point for their host plants (Bethlenfalvay et al. 1988). However, the most significant way by which AM fungi can affect plant-water relations may be through indirect "big plant/little plant" effects, as AM fungi usually increase host plant size aboveground and belowground due to increased 
nutrient acquisition (Augé 2004). Larger plants with extensive roots can more efficiently forage for water in dry soil (Koide 1993).

Arbuscular mycorrhizal fungi are not always beneficial to plants, however, and interact along a mutualism-parasitism continuum (Johnson et al. 1997). Multiple stresses acting together can cause the AM fungi-plant association to become parasitic. For example, AM fungi can be parasitic on plants growing in low nutrient and low light conditions as such conditions restrict the production of photosynthates and allocation of such limited supply of photosynthates to fungal partner can be detrimental to plant fitness (Johnson et al. 1997). Similarly, intense herbivory also depletes plant's photosynthates and can increase the cost of maintaining symbiosis with its fungal partners (Bayne et al. 1984; Daft \& El-Giahmi 1978). However, no studies have documented a change in AM fungi interactions in plants subjected to both drought and belowground herbivory stresses.

In agricultural systems, both herbivory and drought are major problems for farmers. PPN cause major yield losses in crops such as wheat, maize and rice (Bernard et al. 2017). This has led to some interests in the use of AM fungi as biocontrol agents against PPN, which may be an effective Integrated Pest Management tool (Schouteden et al. 2015). However, yield loss in agricultural crops due to PPN is expected to rise in the future and it is expected to be aggravated by climate change effects such as warming and drought (Claflin 1983; Nicol et al. 2011; Somasekhar and Prasad 2012). Therefore, it is important to understand how drought, belowground herbivory, and AM fungal associations interact to affect crop yield. These factors are especially important for perennial bioenergy crops such as switchgrass, which are not replanted every year and so 
are more integrated in their interactions with the soil. Switchgrass is often grown on marginal lands which are not amenable to grain production (Chapotin \& Wolt 2007) and so is exposed to more intense abiotic stress (Lewandowski et al. 2003). Continuous monoculture without between-season crop rotation can lead to the buildup of specialized pests (Coleman-Derr \& Tringe 2014), and more than half a dozen PPN species including Pratylenchus penetrans, Helicotylenchus pseudorobustus, and Hoplolaimus galeatus, are characterized as potentially damaging pests to switchgrass bioenergy systems (Mekete et al. 2011). As a $\mathrm{C}_{4}$ plant, switchgrass is also known to strongly associate with AM fungi in both natural and agricultural systems (Clark et al. 1999; Emery et al. 2017).

Several cultivars of switchgrass have now been bred for bioenergy feedstock purposes and vary widely in their aboveground and belowground traits (Cortese \& Bonos 2013; de Graaff et al. 2013). These cultivars can be broadly assigned to either the upland or lowland ecotypes. Upland ecotype cultivars are more adapted to drier conditions and colder temperatures, while lowland ecotype thrives in areas with warmer temperatures and higher soil moisture (Casler et al. 2004). These ecotypes also can differ in their associations with soil organisms, and lowland cultivars have higher AM fungal colonization than upland cultivars (Emery et al. 2018). Understanding how AM fungi associations and drought affect plant responses to belowground herbivory across different switchgrass ecotypes may help farmers better manage switchgrass in the future.

The main objectives of this study were to investigate the effects of (a) AM fungi and (b) drought on the growth of two switchgrass cultivars exposed to PPN herbivory. I predicted that plants exposed to PPN herbivory and grown with AM fungi would be larger as compared to those grown without AM fungi, and that AM fungi would reduce 
PPN abundance. I also predicted that drought would increase plant susceptibility to PPN damage. I expected that lowland cultivars of switchgrass would have stronger responses to these factors than upland cultivars. Finally, we predicted that the symbiotic role of AM fungi would change to become less beneficial or parasitic when its host plant is subjected to multiple stressors. I tested this in a factorial growth chamber experiment.

\section{MATERIALS AND METHODS}

\section{Experimental Design}

In January 2017, I set up a belowground herbivory growth chamber experiment manipulating the following variables: (1) switchgrass cultivar: Cave-In-Rock or Alamo (two common commercially available switchgrass cultivars), (2) arbuscular mycorrhizal

fungi: addition of Claroideoglomus etunicatum (AM fungi+), or non-AM fungal control (AM fungi-), and (3) drought: (Drought+) or no-drought control (Drought-). The eight treatment combinations were replicated ten times for a total of 80 pots. All pots included belowground herbivores (details below).

\section{Experimental Set-up}

Eighty $10.2 \mathrm{~cm} \times 30.5 \mathrm{~cm}$ pots (Treepots, Stewe and Sons, OR) were filled with non-sterilized play sand (Sakrete of North America, LLC, Sakrete) for this experiment. Cave-In-Rock and Alamo are popular commercial cultivars of switchgrass developed and released by the US Department of Agriculture. Cave-In-Rock is an upland cultivar which is winter hardy and drought resistant (Alderson and Sharp 1994). Alamo is a lowland cultivar developed for superior yield, high seed production and improved seedling vigor (Alderson and Sharp 1994). In a 10-year US Department of Energy sponsored program, 
Cave-In-Rock and Alamo were evaluated as the most productive upland and lowland cultivars respectively (McLaughlin \& Kszos 2005), and so we focused on these two cultivars for our experiment. Seeds of both cultivars of switchgrass (source: Ernst Seeds, PA; 99\% PLS) were surface sterilized in 10\% bleach solution for 5 min, then rinsed with tap water for $5 \mathrm{~min}$, and stored at $4^{\circ} \mathrm{C}$ for 24 hours until they could be planted. Nine seeds of Cave-in-Rock were sown in half of the pots after AM fungi inocula or control media had been added (see below), and seeds covered with a thin layer of sand to prevent AM fungi contamination. Similarly, 9 seeds of Alamo were sown in their assigned treatment pots. Following germination, seedlings were thinned to one seedling per pot. All pots were kept in a greenhouse (average temperature $22.2^{\circ} \mathrm{C}$ ) for 2 weeks during seedling germination, and then moved to a growth chamber $\left(25-27^{\circ} \mathrm{C}\right.$ daytime temperature, $11-14^{\circ} \mathrm{C}$ night time temperature and $14-16$ hours light /dark cycles) for the remainder of the experiment. The pots were rearranged randomly in the growth chamber every ten days. Diluted (eighth strength) Hoagland's solution (Connecticut Valley Biological Supply, Southhampton, MA) was applied in each pot at a rate of $40 \mathrm{ml}$ per pot 3 times, at the start, 30 days and 60 days after the start of the experiment, during the entire experiment to avoid effects of extreme nutrient deficiency.

All pots were inoculated with nematodes 14 days after sowing, to give seedlings a chance to establish and form associations with AM fungi in relevant treatment pots (details below). It has been shown that 14 days is sufficient for AM fungi to colonize young roots and provide resistance against nematodes (De La Peña et al. 2006). We used a migratory endoparasite, Pratelynchus penetrans, which is a common plant parasite on switchgrass (Cassida et al. 2005). We prepared the PPN inoculum from in vivo pure 
cultures that were grown in agar plates with alfalfa roots. Nematodes were extracted from alfalfa roots following Young's method (Young 1954). The alfalfa roots were cut into 1 $\mathrm{cm}$ pieces and soaked in water in a petri dish for 2 days to allow the migration of nematodes out of the roots. The average density of nematodes in the inoculum was $\sim 75$ $\mathrm{ml}^{-1}$ of water which resulted in each pot with $\sim 75$ nematodes, similar to real field densities of PPN (Cassida et al. 2005). Extracted nematodes were washed into a centrifuge tube and stored at $4^{\circ} \mathrm{C}$ until added to experimental pots, when $2 \mathrm{ml}$ of aqueous solution of nematodes were pipetted into 4 small depressions made around the rooting zone of the seedlings. An equal amount of sterile water was added in the pots that did not receive nematode treatment as control. To manipulate the presence or absence of AM fungi, we used pure cultures of the AM fungi species Claroideoglomus etunicatum, a species that is commonly found in grasslands throughout the world and a known associate with switchgrass (Clark et al. 2005). Before switchgrass seeds were sown, $5 \mathrm{~g}$ of AM fungi inocula (Accession NE108A from INVAM, Morgantown, West Virginia) consisting of a mixture of sterile sand, soil, root fragments, AM fungal hyphae and spores was mixed with $5 \mathrm{~g}$ of play sand and spread on top of half of the pots (AM fungi+). $5 \mathrm{~g}$ of INVAM media without AM fungal hyphae and spores mixed with $5 \mathrm{~g}$ play sand was added in the other half of the pots (AM fungi-).

The drought treatment started 14 days after nematode inoculation and was maintained by applying $75 \mathrm{ml}$ of tap water to Drought+ pots once every three days, while pots under no drought (Drought-) were watered daily with the same amount of water. This drought treatment was maintained for 4 weeks, and then the time between watering was extended to every 5 days to ensure sufficient water stress as visually evidenced by 
leaf curl (Shibayama et al. 1993). Three $100 \mathrm{~g}$ of soil samples were collected from all the pots after the plant harvest and were analyzed for soil moisture content using gravimetric method as described by Reynolds (1970). On average, Drought+ pots had ending soil moisture of $7.09 \%$ compared to Drought- pots with soil moisture around $23.7 \%$.

\section{Responses}

The plants were harvested after 90 days and belowground and aboveground responses were assessed. Plant aboveground biomass, number of leaves, shoot length, total root length, belowground biomass, total root surface area, root:shoot ratio, PPN abundance, and AM fungal root colonization were measured. The roots were separated from shoots and rinsed to remove sand particles. Particular care was taken to not damage roots during the harvest. The aboveground biomass was weighed after drying for $48 \mathrm{~h}$ at $65^{\circ} \mathrm{C}$. We used WinRhizo software (Regent Instruments, Canada) to scan roots and measure total root length and root surface area. To determine AM fungi root colonization, we then clipped five $3 \mathrm{~cm}$ subsamples of roots. Root colonization by AM fungi was measured following the methods by Vierheilig et al (2005). Briefly, root samples were warmed for 4 mins in $10 \% \mathrm{KOH}$ solution. The roots were then rinsed with water and treated with acidified water for 15 min to remove $\mathrm{KOH}$ residues. Trypan blue was used to stain the roots for 5-6 min. The roots were rinsed and were soaked overnight in water to de-stain. Ten $1 \mathrm{~cm}$ pieces of roots were mounted on microscope slides and observed under a microscope at 920x magnification (Leica Microsystems, Wetzlar, Germany). The presence and absence of infection (hyphae or arbuscules) in the roots was recorded and expressed as a percentage (Giovannetti \& Mosse 1980). To determine nematode abundance, we clipped an additional five $3 \mathrm{~cm}$ subsamples of roots, and nematodes were 
extracted from the roots following Young's method (Young 1954) described above and counted under microscope. The remaining roots were oven dried at $65^{\circ} \mathrm{C}$ for 24 hours and then weighed to determine dry belowground biomass.

\section{Data analyses}

Plant growth responses to belowground herbivory were analyzed using 3-factor ANOVA models with plant cultivar, presence/absence of AM fungi, and presence/absence of drought as main factors, including all the interaction terms. We followed up with simple linear regression for AM fungi+ pots to test whether there was a relationship between percent AM fungi root colonization (AM fungi+ samples only) and growth responses that were significantly affected by our AM fungi treatments. Goodness of fit chi-squared tests were done to check if the models fit the data. Shoot biomass data were log-transformed to better meet model assumptions. All the analyses were done using R version 3.4.0 (R Core Team 2015).

\section{RESULTS}

\section{Switchgrass cultivars}

In the presence of root herbivores, the Cave-In-Rock cultivar had $8.5 \%$ more aboveground biomass but $20 \%$ fewer total leaves over the entire growth period than Alamo (mean shoot biomass Alamo $=10.5 \mathrm{~g}$, Cave-In-Rock=11.5g; mean total leaves Alamo= 4.16, Cave-In-Rock=3.51; Table 1, Fig. 1a-b). The Alamo cultivar also had 20.2\% higher R:S than Cave-In-Rock (mean R:S Alamo=1.78, Cave-In-Rock=1.48, Fig. 1c). The cultivars did not differ in other growth measures or PPN root densities (Table 1).

Arbuscular mycorrhizal fungi and drought 
At the end of the experiment, AM fungi+ treatments had average root colonization rates of $50.7 \%$, while AM fungi- plants had on average $0 \%$ root colonization, indicating successful manipulation of AM fungi. For both cultivars, plants grown with AM fungi had 66.3\% lesser PPNs (mean PPN abundance AM fungi+=2.02, AM fungi-=3.36, Table 1, Fig. 2 a) in their roots. Percent root colonization by AM fungi explained about $8 \%$ of variation in PPN root abundance for plants associating with AM fungi ( $p=0.16$, Fig. $2 b$ ). There were no significant main effects of AM fungi on plant growth (Table 1).

While drought had no main effect on plant growth (Table 1), AM fungi and drought interacted to affect the root biomass of the plants. Under well-watered conditions, AM fungi decreased root biomass by about 14\% (mean root biomass AM fungi+Drought=7.39 mg, AM fungi-Drought-=8.58 mg, Table 1, Fig. 3). However, AM fungi increased root biomass by $31.1 \%$ under drought conditions (mean root biomass AM fungi+Drought+=8.02 mg, AM fungi-Drought+=6.06 mg, Table 1, Fig. 3).

\section{DISCUSSION}

In this study, we showed that AM fungi provided benefits to switchgrass, even under multiple stresses. Arbuscular mycorrhizal fungi reduced PPN abundance in both cultivars of switchgrass independent of drought, though this did not result in improved plant growth. This result partially corroborates previous findings from other studies in switchgrass and other crop systems. Suppressive effects of AM fungi on root-knot and burrowing nematodes in peach, almond, tomato, coffee, and banana plants have been observed previously (Alban et al. 2013; Calvet et al. 2001; Koffi et al. 2013; Vos et al. 2012). A study by Emery et al. (2017) found that the abundance of PPN were lower in 
switchgrass than another perennial bioenergy crop, miscanthus, and that this correlated with higher AM fungi colonization rates in switchgrass. Similarly, the results of this study showed a negative relationship between AM fungi root colonization density and PPN abundance. While we did not study the specific mechanism of PPN suppression by AM fungi in this experiment, we suspect that AM fungi excluded PPN by suppressing infection site availability through competition for space (Schouteden et al. 2015). Arbuscular mycorrhizal fungi were inoculated 14 days before PPN, therefore establishing their symbioses before the nematodes could colonize roots (De La Peña et al. 2006). In other studies, a well-established AM fungus colonization appears to be an essential condition for biocontrol (Pozo et al. 2002). For example, a study on Meloidogyne incognita and sweet passion fruit (Passiflora alata) showed that a well-established symbiosis prior to the PPN's inoculation reduced PPN reproduction while co-inoculation had no effects (Anjos et al. 2010). While the lack of growth response to PPN reduction is a bit surprising, other studies have found AM fungi to increase herbivore performance by increasing host plant quality (Koricheva et al. 2009). The lack of short-term growth response to reduction in PPN in our study may be due to contrasting effects of AM fungi having high resource demands on young plants (Janos et al. 2013), while also providing some protection against PPN. Since switchgrass is a perennial species, studies on the long-term effects of AM fungi associations on PPN abundance and plant growth are warranted. Additionally, plants growth response to herbivory may depend upon the species of AM fungi that associates with the host. In an aboveground herbivory experiment, Bennett and Bever (2007) found increased plant growth with Glomus sp. association, decreased growth with Archaeospora sp. association and neutral growth with 
Scutellospora association. We used only one AM fungal species in our experiment which induced a neutral growth response to herbivory, but other AM fungal species may have different effects.

In this study, we did not observe main drought effects on any of the plant responses. One reason we suspect is because our drought treatments were not very severe, as evidenced by plants responding with leaf curl rather than wilting. Additionally, switchgrass is known to be tolerant to extreme moisture conditions and can germinate, establish, and flower at low moisture or flooded conditions (Xie et al. 2014). The results of this study are consistent with this observation, even considering that all plants were also subjected to belowground herbivory.

We did not see any reversal in the symbiotic role of AM fungi under multiple stresses as no negative effects of AM fungal associations were observed when plants were exposed to both drought and herbivory. In fact, AM fungi increased root biomass under drought and herbivory conditions, which could help plants better access soil water. Additionally, it is known that drought can adversely affect soil nitrogen mineralization (Bloem et al. 1992) and plant uptake of soil phosphorus (Pinkerton \& Simpson 1986), thus indirectly affecting plant growth. In this study, improved root growth of mycorrhizal plants under drought conditions could potentially enhance uptake of nitrogen or phosphorus. While the role of AM fungi in alleviation of drought effects has been widely established (Al-Karaki et al. 2004; Wu \& Xia 2006), this study suggests that AM fungi can still provide similar benefits under multiple stresses. While other measures of plant growth were not affected, the relatively short period of the experiment might have been insufficient for both the stresses to fully affect plant growth. However, both root 
herbivory and drought strongly affect seedling establishment and growth (Moles \& Westoby 2004). It also may be that other measures of plant performance may be more responsive to AM fungi under biotic and abiotic stresses. For example, some previous studies have shown that AM fungi provide ameliorative effects for plants during drought via physiological responses such as increased leaf water potential, turgor and relative water content (Davies Jr et al. 1992). Further studies should be conducted to study the responses of plants to AM fungi under multiple stresses. However, our results suggest that the presence of multiple soil stresses do not necessarily reverse effects of plant-AM fungi associations.

Finally, our study showed that the Cave-in-Rock cultivar was bigger overall, which contrasts with other studies showing that lowland ecotypes usually produce more aboveground biomass than upland ecotypes (Lemus et al. 2002). This may indicate that Cave-in-Rock and other upland cultivars may be more tolerant to belowground herbivory than lowland cultivars, despite some studies showing that lowland cultivars tend to be more resistant to aboveground herbivory (Koch et al. 2018). Almost nothing is known about whether PPN vary in their associations with different switchgrass cultivars, though one study has shown that Pratylenchus preferred upland cultivars of switchgrass (Casssida et al. 2005). However, that same study showed that other PPN genera preferred lowland cultivars. Further work is needed to characterize differences in switchgrass cultivar susceptibility to PPN.

We saw no differences in responses to AM fungal associations or drought between the two cultivars. Upland ecotypes are usually considered more drought tolerant than lowland ecotypes (Stroup et al. 2003), but many studies on this have been conducted 
in controlled settings that do not include belowground herbivory. While lowland ecotypes have increased AM fungal root colonization rates (Emery et al. 2018), these studies focused on mature switchgrass stands in field conditions. Seedlings and mature plants can vary in their associations with AM fungi (Rodríguez-Morelos et al. 2014), which may explain our lack of differences.

Overall, our results support the importance of the AM fungi for mitigating drought and herbivory stresses on switchgrass plants and warrant further research on the role of AM fungi for plant protection against simultaneous biotic and abiotic stresses in both agricultural and natural settings. Immediate future researches should focus on understanding how plants respond to AM fungal colonization along a gradient of biotic or abiotic stresses, as they occur in nature. 
Table 1: Results of a three-way ANOVA testing for significant differences in aboveground and belowground responses to switchgrass cultivar, AM fungi, and drought under belowground herbivory stress. Significant effects $(\mathrm{p}<0.05)$ are in bold.

\begin{tabular}{|c|c|c|c|c|c|c|c|c|c|c|c|c|c|c|}
\hline \multirow[t]{2}{*}{ Factors } & \multicolumn{2}{|c|}{ Shoot biomass (g) } & \multicolumn{2}{|c|}{ Total leaves } & \multicolumn{2}{|c|}{$\begin{array}{l}\text { Root } \\
\text { biomass } \\
\text { (g) }\end{array}$} & \multicolumn{2}{|c|}{$\begin{array}{l}\text { Root } \\
\text { length } \\
(\mathrm{cm})\end{array}$} & \multicolumn{2}{|c|}{$\begin{array}{l}\text { Root surface area } \\
\left(\mathrm{cm}^{2}\right)\end{array}$} & \multicolumn{2}{|l|}{$R: S$} & \multicolumn{2}{|c|}{$\begin{array}{l}\text { PPN (count/cm root } \\
\text { length) }\end{array}$} \\
\hline & $\mathrm{F}$ & $\mathrm{P}$ & $\mathrm{F}$ & $P$ & $\mathrm{~F}$ & $\mathrm{P}$ & $\mathrm{F}$ & $\mathrm{P}$ & $\mathrm{F}$ & $\mathrm{P}$ & $\mathrm{F}$ & $P$ & $\mathrm{~F}$ & $P$ \\
\hline AM fungi & 2.35 & 0.12 & $<0.01$ & 0.97 & 0.30 & 0.58 & 0.86 & 0.35 & 1.62 & 0.20 & 0.99 & 0.32 & 10.23 & $<0.01$ \\
\hline Cultivar & 8.8 & $<0.01$ & 24.85 & $<0.01$ & 0.58 & 0.44 & 3.1 & 0.08 & 0.63 & 0.42 & 5.18 & 0.02 & 0.01 & 0.91 \\
\hline Drought & 1.99 & 0.16 & 1.89 & 0.17 & 1.78 & 0.18 & 1.91 & 0.17 & 1.42 & 0.23 & 2.08 & 0.15 & 0.16 & 0.68 \\
\hline AM fungi x Cultivar & 2.05 & 0.15 & 0.71 & 0.40 & 0.11 & 0.73 & 3.10 & 0.08 & 1.03 & 0.31 & 0.65 & 0.42 & 1.78 & 0.18 \\
\hline AM fungi $x$ Drought & 1.67 & 0.20 & 0.09 & 0.76 & 4.68 & 0.03 & 3.08 & 0.08 & 2.84 & 0.09 & 3.02 & 0.08 & 1.183 & 0.28 \\
\hline Cultivar x Drought & 0.22 & 0.63 & 0.50 & 0.47 & 0.05 & 0.82 & 0.14 & 0.70 & $<0.01$ & 0.92 & 0.17 & 0.67 & 0.03 & 0.84 \\
\hline AM fungi x Drought $x$ Cultivar & 1.06 & 0.30 & 0.21 & 0.64 & 0.07 & 0.78 & 0.16 & 0.68 & 0.40 & 0.52 & 2.88 & 0.09 & 0.62 & 0.43 \\
\hline
\end{tabular}




\section{Figure Legends}

Figure 1. Difference in (a) shoot biomass, (b) number of leaves, and (c) root to shoot biomass ratio between the two switchgrass cultivars $(\mathrm{CIR}=$ Cave in Rock, $\mathrm{AL}=\mathrm{Alamo})$ under belowground herbivory. Statistically different average values found between treatments with Tukey's HSD $(p<0.05)$ test are indicated by a horizontal bar with an asterisk above. Vertical bars show means \pm 1 SE. Asterisk indicates significant differences between treatments at $\mathrm{p}<0.05$.

Figure 2. (a) PPN abundance in the roots of switchgrass in response to AM fungi manipulation (+/-) (b) Relationship between PPN abundance and \% AM fungal colonization of roots. PPN abundance per root sample is the abundance of PPN in ten 1 $\mathrm{cm}$ long root sections from a sample. Vertical bars show means $+/$ - SE. Asterisk indicates significant differences between treatments at $\mathrm{p}<0.05$.

Figure 3. Root biomass of PPN-exposed switchgrass in response to AM fungi (+/-) and drought (+/-) manipulation. Statistically different average values found between treatments with Tukey's HSD $(p<0.05)$ test are indicated by a horizontal bar with an asterisk above. Vertical bars show means + /- SE. 
Figure 1
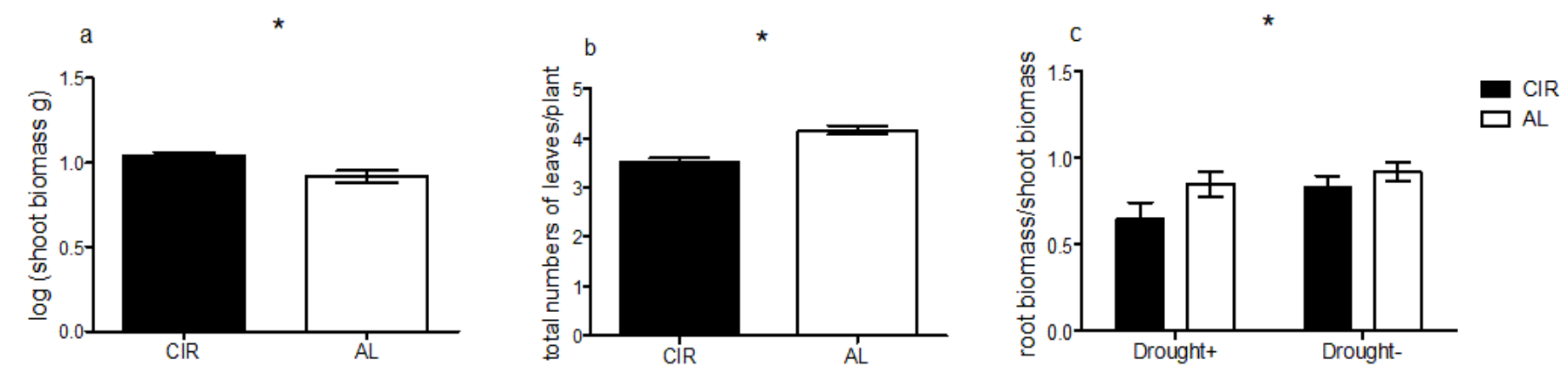
Figure 2
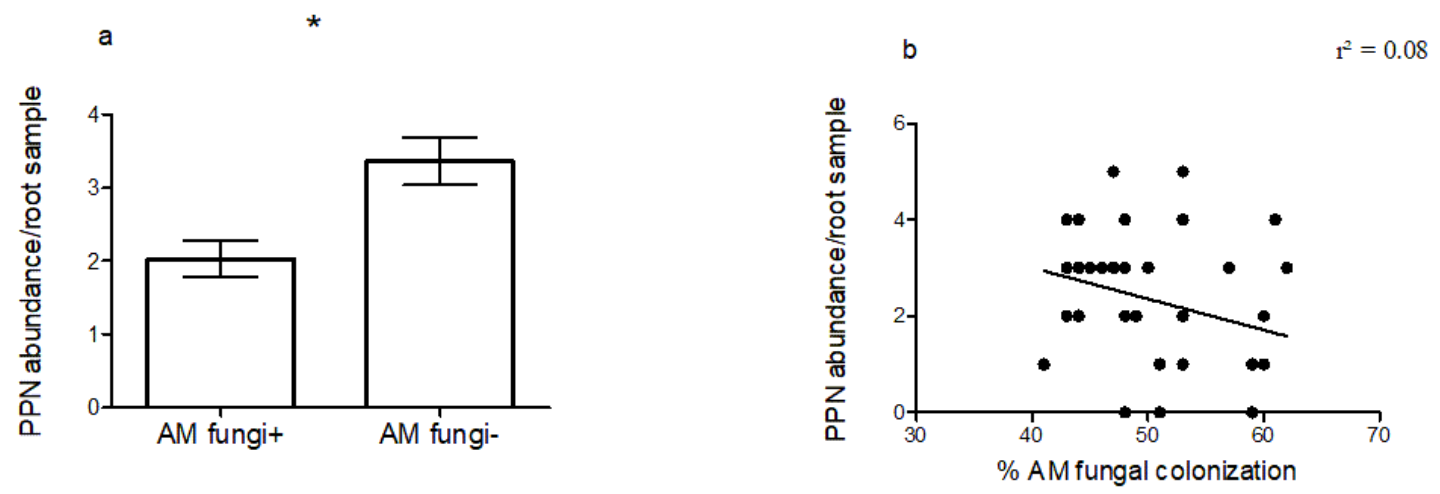
Figure 3

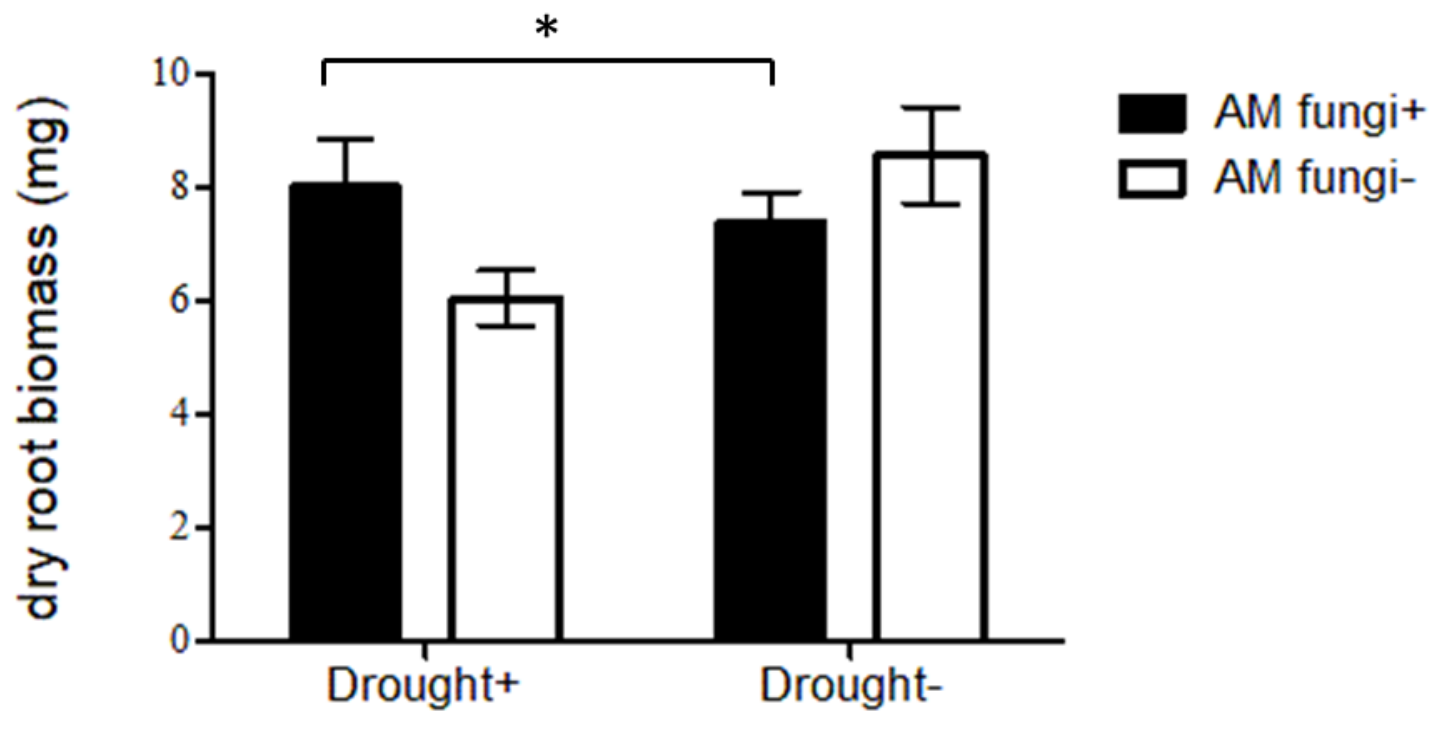




\section{CHAPTER III}

\section{DO SOIL BIOTIC AND ABIOTIC FACTORS HAVE DIFFERENT EFFECTS ON ABOVEGROUND AND BELOWGROUND LIGNIN COMPOSITION IN}

SWITCHGRASS?

\section{SUMMARY}

Plant lignin content and composition, which limit cell wall digestibility and efficiency of cellulose conversion to bioethanol, can be influenced by belowground biotic and abiotic factors. Switchgrass (Panicum virgatum) is a leading lignocellulosic biofuel crop and forms strong belowground associations with arbuscular mycorrhizal fungi (AMF), is susceptible to belowground plant parasitic nematodes (PPN), and when grown in monoculture generally requires $\mathrm{N}$ fertilization. The main objectives of the study were to investigate the effects of $\mathrm{N}$ fertilizer and belowground organisms on lignin content and composition in switchgrass. We also evaluated whether these factors had varying belowground (local) or aboveground (systemic) effects on plants by analyzing lignin composition of leaves, stem, and roots separately. We manipulated these factors in a field study in 2017 using biocide applications to reduce soil fungi and nematodes. Combined biocide application reduced p-hydroxyphenyl $(\mathrm{H})$ unit in the leaves by $14 \%$ and enhanced syringyl:guaiacyl $(\mathrm{S}: \mathrm{G})$ ratio in stem by $2 \%$. Application of fungicide alone increased 
stem syringyl (S) unit by $12.4 \%$ as compared to control plots and $11.1 \%$ as compared to nematicide plots. Overall, fertilizer increased total stem lignin by $3 \%$, stem S unit by $6.7 \%$ and stem $S: G$ ratio by $10 \%$, whereas it reduced the amount of $\mathrm{H}$-unit in the roots by $11 \%$. While the effects of $\mathrm{N}$ fertilizer were more pronounced in our study, changes to soil organisms had similar magnitudes of effect for some measures of lignin, indicating that these belowground interactions may be important for growers to consider in the future.

\section{INTRODUCTION}

Lignocellulosic biofuels such as switchgrass are gaining traction as sustainable and alternative energy sources as the economic and environmental costs of conventional fossil fuels and grain-based biofuels have risen (Scarlat and Dallemand 2011). The main benefits of these fuels come from efficiently converting cellulose from plant biomass into bioethanol. However, acid pretreatment and enzymatic digestion, the two main steps of the conversion, are limited by total lignin content in plant cell walls (Chen and Dixon 2007). Additionally, the monomeric composition of lignin in plants can also affect the efficiency of cellulose conversion to bioethanol ( $\mathrm{Li}$ et al. 2010). For example, biomass with higher syringyl: guaiacyl $(\mathrm{S}: \mathrm{G})$ ratios is desirable from a bioenergy standpoint because S-rich lignin has predominantly linear chains with less crosslinking than G-rich lignin and has lower recalcitrance to enzymatic degradation (Studer et al. 2011). This importance of $\mathrm{S}: \mathrm{G}$ ratio in lignin composition has been clearly demonstrated in wood pulp production research (Huntley et al. 2003). However, grasses differ from woody dicots by also having a significant proportion (4-15\%) of p-hydroxyphenyl lignin $(\mathrm{H})$ (Barrière et al. 2004), and very little is known about what regulates the $\mathrm{H}$ unit in plants. 
For bioenergy purposes, any significant alteration in the proportion of all these lignin units can have potential implications for digestibility.

Various abiotic factors affect plant lignin content and monomeric composition. Specifically, temperature and drought affect lignin content in pine seedlings, temperate monocots, and various specific plant tissues (Gindl et al. 2000; Hausman et al. 2000; Moore et al. 2008; Sanaullah et al. 2012; Terzi et al. 2013; Vincent et al. 2005; Yang et al. 2006). Soil nitrogen (N), an important abiotic factor in both natural and agricultural systems, generally increases plant lignin content (Liu et al. 2016), although the mechanism by which fertilization may affect lignin composition is unclear. In one study conducted in a poplar system, high $\mathrm{N}$ fertilizer increased the minor $\mathrm{H}$ unit but decreased the $\mathrm{S}: \mathrm{G}$ ratio (Moura et al. 2010). However, the relationship between $\mathrm{N}$ fertilizer and lignin may not be straightforward, as the effects of $\mathrm{N}$ on lignin seem to vary across plant tissues and with age (Blodgett et al. 2005; Entry et al. 1998; Kostiainen et al. 2004). For switchgrass grown as bioenergy feedstock, $\mathrm{N}$ fertilizers can significantly increase switchgrass biomass (Lemus et al. 2008). However, this may have unintended effects on the digestibility of biomass via effects on lignin quantity and quality, despite growing interest in lignin-based bioenergy products (Lemus et al. 2008).

Interactions between plants and belowground organisms also affect plant lignin content and composition. For example, $6 \%$ to $21 \%$ of the variation in lignin in barley cultivars was attributed to belowground biotic interactions (Bennett et al. 2015). Increased lignification is expected in many types of biotic interactions. For example, pathogens and herbivores such as plant-parasitic nematodes (PPN) generally trigger an increase in plant lignin as a defense against damage and infection (Bonello and Blodgett 
2003; Parrott et al. 2002). Some beneficial symbiotic interactions can also increase plant lignin. For example, arbuscular mycorrhizal fungi (AMF) are ubiquitous in soils and increase lignin in pepper xylem vessels (Goicoechea-Preboste et al. 2010). AMF also can induce lignification, potentially conferring reinforcement to the cell walls against pathogen invasion (Morandi 1996). However, AMF can provide ameliorative effects under stressful environmental conditions, thus reducing plant lignin content (Baslam et al. 2014; Lee et al. 2012).

Lignin content also varies across organs within a plant. Generally, lignin content in leaves is lower than in stems, and increases with increasing distance from the plant apex (Sarath et al. 2008). For example, in switchgrass, lignin abundance is lowest in the $1^{\text {st }}$ internode and highest in the $6^{\text {th }}$ internode (Sarath et al. 2008). This is important because the majority of the cellulose and hemicellulose used in bioethanol conversion occurs in the stem parenchyma tissues. Thus, it is desirable to have low lignin levels especially in the stem (Byrt et al. 2011). Additionally, plant-soil interactions may have only localized effects on plants, increasing lignin in roots but not in aboveground tissues. For example, in pine seedlings, high $\mathrm{N}$ fertilizer reduced root lignin content without affecting shoot lignin (Entry et al. 1998). Such differential accumulation of lignin in roots and shoots can indicate whether plant responses are local or systemic. No studies have documented lignin responses to soil factors in switchgrass.

The goal of this study was to examine the effects of belowground abiotic and biotic factors on lignin quantity and composition in switchgrass, both in above- and belowground plant tissues. Switchgrass forms strong associations with AMF (Brejda et al. 1993) and is susceptible to several belowground plant parasitic nematodes such as 
Pratelynchus penetrans, Helicotylenchus pseudorobustus, and Hoplolaimus galeatus when grown in monocultures (Mekete et al. 2011). Additionally, $\mathrm{N}$ fertilization is recommended for growers of switchgrass and other lignocellulosic bioenergy crops (Engbers 2012; Menden et al. 2007) and so it is critical to understand how both biotic and abiotic factors belowground may influence lignin in these crops. The main objectives of the study were to investigate the effects of $\mathrm{N}$ fertilizer application and plant interactions with AMF and nematodes on lignin content and monomeric composition. A secondary goal was to evaluate whether these factors had varying belowground (local) or aboveground (systemic) effects on plants by analyzing lignin composition of leaves, stem, and roots separately. We predicted that lignin content in roots would decline with reduced AMF and nematode abundance. We also expected increased lignin at the wholeplant level in response to $\mathrm{N}$ addition, since $\mathrm{N}$ quickly becomes part of the soil cation exchange complex and is readily assimilated by plants (Scarsbrook 1965). Finally, we expect to see higher $\mathrm{S}: \mathrm{G}$ ratios and lower p-hydroxyphenyl levels in response to fertilizer (Pitre et al. 2007), but lower S:G ratios corresponding to higher rigidity with AMF colonization and nematode herbivory.

\section{MATERIALS AND METHODS}

Study Site

We conducted the experiment at the W.K. Kellogg Biological Station Long Term Ecological Research (KBS LTER) site in Michigan USA (42 $\left.23047^{\prime \prime} \mathrm{N}, 85^{\circ} 22026^{\prime \prime} \mathrm{W}\right)$ as part of the Cellulosic Biofuels Diversity Experiment. The average precipitation in this site is $810 \mathrm{~mm} \mathrm{yr}^{-1}$ and soils are Kalamazoo series fine loamy, mixed, mesic Typic Hapludalfs (Muñoz and Kravchenko 2011). The Cellulosic Biofuels Diversity 
Experiment was established in 2008 to compare 12 different biofuel cropping systems, including two cultivars of switchgrass ("Cave-in-Rock" and "Southlow"; each planted at a rate of $\left.3.9 \mathrm{~kg} \mathrm{ha}^{-1}\right)$ grown at two levels of fertilization $\left(56 \mathrm{~kg} \mathrm{~N} \mathrm{ha}^{-1}\right.$ and unfertilized). The four switchgrass treatment combinations were planted in $9 \mathrm{~m} \times 27 \mathrm{~m}$ plots, replicated four times in randomized blocks. The treatment combinations were interspersed with the other eight treatments which were not part of our study here. Urea and ammonium nitrates $(28 \% \mathrm{~N})$ were applied in combination to the relevant switchgrass treatment plots every year in the spring. For the control of broadleaf weeds, the herbicide Drive (quinclorac; BASF Corp, NC) was applied at the rate of $0.56 \mathrm{~kg} \mathrm{ha}^{-1}$ following planting in 2009-10. Harvesting of the switchgrass plots were done annually at the end of each growing season (Oct/Nov). Additional details about the experiment are available elsewhere (Michigan State University 2020).

\section{Biocide Experiment}

To manipulate switchgrass associations with AMF and nematodes, we set up a biocide experiment with four treatments in the 16 switchgrass plots of the LTER Cellulosic Biofuel Diversity Experiment site at KBS in June of 2017. In each $9 \mathrm{~m} \times 27 \mathrm{~m}$ plot, we set up four $2 \mathrm{~m} \times 2 \mathrm{~m}$ microplots along the west side of the plot: 1) control, 2) fungicide, 3) nematicide, and 4) fungicide + nematicide. We used the commercial fungicide Topsin (Nippon Soda Company, Ltd) to reduce soil fungi, particularly AMF. Topsin is widely used in field studies of mycorrhizal fungi (Wilson and Williamson 2008). The fungicide was applied by hand in 3.7-7.5 1 of water as a soil drench every 2 weeks throughout the growing season (June to August) of 2017 at the rate of $4.4 \mathrm{~g} \mathrm{~m}^{-1}$. We used a commercial nematicide, Nimitz (ADAMA, USA), to reduce soil nematodes. 
Nimitz is a low toxicity and narrow spectrum nematicide and previous studies have shown that it is effective in the control of both migratory and sedentary nematodes (Oka 2014). Nimitz was applied to plots by hand twice during the growing season at a rate of $0.3 \mathrm{~g} \mathrm{~m}^{-1}$ (June) and $0.5 \mathrm{~g} \mathrm{~m}^{-1}$ (July) active ingredient, mixed in $100 \mathrm{ml}$ of silica sand. The applications of both biocides were made prior to rainfall events. Control plots received equal amounts of silica sand and/or water without biocides.

\section{Soil Organisms:}

To evaluate the effectiveness of the biocides on AMF and nematodes, we collected soil and root samples in October 2017. Ten soil cores $(2 \mathrm{~cm}$ x $15 \mathrm{~cm})$ were collected in each microplot and composited for analyses. Additionally, 4-5 individual tillers per microplot were uprooted in both July and October to collect roots for AMF analyses (Oct only) and for lignin analyses (described in detail below). To characterize AMF activity, soils were processed for extra-radical hyphae (ERH) by vacuum-filtering $20 \mathrm{~g}$ subsamples through $45 \mu \mathrm{m}$ filters and mounting filters on slides following methods described by Staddon et al. (1999). Hyphal length was estimated using the grid intersection method (McGonigle et al. 1990; Staddon et al. 1999). AMF root colonization was determined using the wet sieve process (Milchunas 2012) and (Vierheilig et al. 2005) method. Briefly, ten $3 \mathrm{~cm}$ fine root subsamples were clipped and cleared in $10 \%$ Potassium Hydroxide solution and stained using the ink-vinegar method (Vierheilig et al. 1998) and scored as a percentage of fields of view at 200X magnification based on the presence of fungal hyphae, arbuscules or vesicles (McGonigle et al. 1990). At harvest time, fungicide application had reduced soil ERH by $43 \%$ and AMF root colonization by $32 \%$ compared to the control. Soil nematode abundance was measured by sieving and 
centrifuging $100 \mathrm{~g}$ soil subsamples from each microplot following protocols by (Jenkins 1964). The extracted nematodes were counted and preserved in $3 \%$ formalin solution for storage. Nematicide application reduced total nematode abundance by $47 \%$ compared to the control. When applied in combination, the biocides reduced nematodes by $42 \%$, soil ERH by $51 \%$, and root AMF colonization by $38 \%$.

\section{Plant responses:}

Biomass subsamples for lignin analyses were collected from the whole tillers and associated roots at mid-growing season in August and at harvest time in October 2017 from each microplot. Tillers (separated into leaf and stem tissues) and roots were dried at $65^{\circ} \mathrm{C}$ for $24 \mathrm{~h}$. Then the leaf, stem and root samples from each microplot were ground using a Thomas Wiley Mill (Thomas Scientific, NJ) with a $40 \mu \mathrm{m}$ mesh screen. $100 \mathrm{mg}$ ground tissue samples were sent to Great Lake Bioenergy Research Center (GLBRC) Cell Wall Facility at Michigan State University for analysis of lignin monomeric composition using acetyl bromide solubilization method (Foster et al. 2010). Additionally, acid detergent lignin (ADL) was analyzed using a $\mathrm{ANKOM}^{200}$ fiber analyzer (Macedon, NY) to assess total lignin content.

\section{Statistical analysis}

We analyzed data using two-factor linear mixed effect models with biocide treatment (4 levels) and $\mathrm{N}$ fertilizer (2 levels) as the main factors and switchgrass cultivar and season as covariates. Experimental block was also included in the models as a random effect. Tukey HSD (Abdi and Williams 2010) was used to perform post-hoc analyses when overall models were significant. All statistical analysis was performed 
using the lme4 and lmerTest packages in R version 3.6.1 (R Core Team 2017). While switchgrass cultivar and season were often significant in our models (Tables 2-4), they were not specifically relevant to our outlined research objectives and we were unable to explore these effects further due to limited sample sizes.

\section{RESULTS}

\section{N fertilizer effects on lignin}

Leaf lignin abundance and composition did not respond to $\mathrm{N}$ fertilizer application (Table 2, Fig. 4). However, total stem lignin increased by $3 \%$ when $\mathrm{N}$ fertilizer was added (Table 3, Fig. 5a). This was most likely due to an overall increase in stem $\mathrm{S}$ unit abundance by $6.7 \%$ with the application of $\mathrm{N}$ fertilizer (Fig. 5b). This consequently resulted in an increase in stem S:G ratio by about 10\% (Table 3, Fig. 5c). Belowground, only the $\mathrm{H}$ unit of root lignin responded to the fertilizer treatment, where $\mathrm{N}$ fertilizer reduced the amount of the $\mathrm{H}$ unit by $11.1 \%$ (Table 4 , Figure 3 ).

\section{Soil biotic effects on lignin}

Manipulation of AMF and nematodes via biocide application had significant effects on both leaf and stem lignin monomeric composition, but surprisingly not on root lignin composition or total lignin abundance (Tables 2-4). Reducing AMF and soil nematodes together decreased the abundance of the $\mathrm{H}$ unit in leaf lignin by $14 \%$ and increased the stem $S: G$ ratio by $2 \%$ compared to the control (Table 2-4, Fig. 4, 5c). Reducing AMF alone increased the amount of S unit in stem lignin by $12.4 \%$ as compared to the control unmanipulated plots, and $11.1 \%$ compared to nematicide plots (Table 3, Fig. 5b). 


\section{DISCUSSION}

Does $N$ fertilizer affect switchgrass lignin content and composition?

$\mathrm{N}$ fertilizer affected switchgrass lignin content and composition aboveground and belowground, although the effects were observed more frequently in the aboveground stem tissues where $\mathrm{N}$ fertilizer increased the total lignin, $\mathrm{S}$ unit abundance, and the $\mathrm{S}: \mathrm{G}$

ratio. A decrease in the $\mathrm{H}$ unit was the only root lignin response to $\mathrm{N}$ fertilizer. Since high lignin content in aboveground tissues is not generally desirable from a grower's perspective (Chen and Dixon 2007), and since $\mathrm{N}$ fertilization is generally recommended in switchgrass production (Rinehart 2006; Sanderson et al. 2006), increase in lignin content could become an unintended consequence of standard switchgrass management practices. On the other hand, this increase was mostly due to increases in the S unit in stem tissues, which may improve lignin conversion efficiency (Li et al. 2010). The results of this study generally support other studies which have shown that $\mathrm{N}$ fertilization increases plant lignin content (Emery et al. 2020) but more work is needed on the economics of increasing total lignin abundance versus changes in composition due to $\mathrm{N}$ fertilization.

The belowground effects of $\mathrm{N}$ fertilization are unlikely to have significant economic consequences for growers. While grasses like switchgrass contain significant amount of $\mathrm{H}$ unit (Vogel 2008), the importance of this unit has not yet been established from a biofuel perspective. Additionally, for biofuel production from switchgrass, aboveground biomass is much more important than belowground biomass since the majority of total biomass comes from the aboveground tissues (Frank et al. 2004), and so 
the effects of $\mathrm{N}$ fertilizer on root $\mathrm{H}$ unit may not be of much interest to the biofuel industry.

Do soil organisms affect switchgrass lignin content and composition?

Contrary to our predictions, there were no effects on the total amount of lignin in switchgrass in response to AMF and nematode reductions either above- or belowground. Further, effects on switchgrass lignin composition were only seen in aboveground tissues, particularly stems, where we saw an increase in the $\mathrm{S}$ unit in response to biocide application. This lack of effect on total lignin or belowground lignin composition is surprising given what is known about plant responses to soil organisms. Several previous studies have demonstrated an increase in lignification in response to symbiotic organisms such as AMF and nematodes (Bennett et al. 2015). For example, AMF penetrates the root cortex of the host plant (Allen 1996) and in doing so are known to prime the salicylic acid pathway which is widely known to prime plant defensive responses such as lignin biosynthesis (He and Wolyn 2005; Zhang et al. 2013). There is thus a potential for AMF to influence lignin production. AMF are also found to prime genes involved in lignin biosynthesis as a response to attack by plant parasitic nematodes (Schouteden et al. 2015). We thus expected that biocides would reduce lignification, especially in roots where symbiotic organisms were directly reduced. Only a very few studies have attempted to explore the effects of soil organisms on lignin composition, but at least one previous study documented an increase in the $\mathrm{S}$ unit upon infection by Puccinia graminis, a fungal causative agent of stem rust in wheat (Menden et al. 2007), which contradicts our findings. We observed higher levels of $\mathrm{H}$ unit in leaf lignin but lower levels of $\mathrm{S}$ unit and $\mathrm{S}: \mathrm{G}$ ratio in stem lignin of our control plants. Our findings may be a result of the 
potential interactions between AMF and nematodes belowground. Plant parasitic nematodes are reported to enhance lignification in host plants (Huang et al. 2016) which may be ameliorated by AMF which are also known to provide biocontrol against such nematodes by wide array of mechanisms (Schouteden et al. 2015). In any case, increases in stem $\mathrm{S}: \mathrm{G}$ ratios as soil organism abundance was reduced could be a positive outcome for growers as it may increase the digestibility of biomass.

The mechanism for the observed effects of biocides in the $\mathrm{H}$ unit of leaves remains unclear. The importance of the $\mathrm{H}$ unit on the digestibility of plant biomass is unknown, thus we cannot determine the potential economic importance of these effects. Grasses like switchgrass contain a relatively large proportion of $\mathrm{H}$ unit (about 15\%), and we assume that such units are involved in vital mechanical, vascular, or defense functions (Vogel 2008). The results of this study support the assumption that plant elicitor responses to symbionts alter the monomeric composition of lignin by depositing more $\mathrm{p}$ hydroxyphenyl units (Asada and Matsumoto 1972; Lange et al. 1995). However, given that the response in this study was observed in leaves only, other unknown mechanisms may be operating. Regardless, it is clear that AMF and nematodes do not have only localized effects on plant lignin, but instead have effects on important aboveground tissues at a systemic scale. Since enzymatic recalcitrance comes mainly from stem tissues which contain more lignin than leaves (Baslam et al. 2014), soil organisms may indeed have economic consequences in terms of bioenergy conversion.

Here, we specifically focused on manipulating AMF with our fungicide applications; however, other pathogenic or non-pathogenic fungi also may have been reduced. Since biocides are widely used by growers to control pathogens in a variety of 
different agronomic systems, it is imperative to understand the effects of such treatments on biofuel crops. The results of this study indicate that there may be complex multitrophic interactions in the soil among AMF, PPNs and pathogenic fungi which could explain the lack of fungicide-only or nematicide only responses (GoicoecheaPreboste et al. 2010; Schouteden et al. 2015).

While $\mathrm{N}$ fertilization effects on lignin generally were more common than effects of reduced biotic interactions, both $\mathrm{N}$ fertilization and reduced soil organisms had similar effects on S:G ratio in stems. Since the biotic manipulations occurred only during a single field season, while the $\mathrm{N}$ treatment was long-term over a 10-year period, this indicates that plants are able to respond quickly to changes in belowground conditions. It is also notable that we found no interactive effects between $\mathrm{N}$ fertilization and biocide applications. There can be considerable variation in the effects of AMF on lignin as demonstrated by previous studies and much of the effects seem to be dictated by the surrounding abiotic factors (Baslam et al. 2014; Goicoechea-Preboste et al. 2010; Lee et al. 2012; Sabia et al. 2015). However, we did not detect any evidence for such a pattern.

\section{Conclusion}

Overall, both biotic and abiotic soil factors had more frequent effects on lignin composition compared to lignin abundance in this study. $\mathrm{N}$ fertilization seems to be a more important regulator of lignin quantity and quality than soil organisms, though for some responses such as S:G in stem tissues, these two factors had similar effect sizes. Even given the relatively minor effects on total lignin, changes in lignin composition may greatly affect biomass digestibility. The economic importance of the observed effects needs to be explored in depth, especially in the context of large-scale farming, before 
making any recommendations for agronomic management practices. Ultimately, tradeoffs between digestibility and plant fitness in terms of yield involved with having lower lignin should be evaluated carefully against any potential biofuel gains. 
Table 2. Results of two-way general linear models testing for significant differences in lignin content and composition of switchgrass leaf tissue in response to biocides and N fertilizer application. Significant effects $(\mathrm{p}<0.05)$ are in bold.

\begin{tabular}{|c|c|c|c|c|c|c|c|c|c|c|}
\hline \multirow[t]{2}{*}{$\begin{array}{l}\text { Source of } \\
\text { Variation }\end{array}$} & \multicolumn{2}{|c|}{$\begin{array}{l}\text { Total lignin } \\
(\mathrm{ug} / \mathrm{ml})\end{array}$} & \multicolumn{2}{|c|}{$\begin{array}{l}\text { Syringyl unit }(S) \\
(\mathrm{ug} / \mathrm{ml})\end{array}$} & \multicolumn{2}{|c|}{$\begin{array}{l}\text { Guaiacyl unit } \\
\text { (G) } \\
(\text { ug/ml })\end{array}$} & \multicolumn{2}{|c|}{$\begin{array}{l}\text { p-hydroxyphenyl } \\
\text { unit } \\
\text { (H) } \\
\text { (ug/ml) }\end{array}$} & \multicolumn{2}{|l|}{$S: G$} \\
\hline & $\mathrm{F}$ & $\mathrm{P}$ & $\mathrm{F}$ & $\mathrm{P}$ & $\mathrm{F}$ & $\mathrm{P}$ & $\mathrm{F}$ & $\mathrm{P}$ & $\mathrm{F}$ & $\mathrm{P}$ \\
\hline N-Fertilizer & 0.95 & 0.33 & 2.01 & 0.15 & 0.62 & 0.43 & 0.01 & 0.91 & 2.68 & 0.10 \\
\hline Biocides & 1.17 & 0.32 & 1.54 & 0.20 & 1.02 & 0.38 & 2.91 & 0.03 & 0.93 & 0.42 \\
\hline $\begin{array}{l}\text { N-Fertilizer } \mathrm{x} \\
\text { Biocides }\end{array}$ & 0.34 & 0.79 & 0.42 & 0.73 & 0.29 & 0.82 & 0.48 & 0.61 & 0.38 & 0.76 \\
\hline Cultivar & 6.82 & 0.01 & 18.67 & $<0.01$ & 3.73 & 0.60 & 1.18 & 0.27 & 22.40 & $<0.01$ \\
\hline Season & 189.23 & $<0.01$ & 143.68 & $<0.01$ & 178.85 & $<0.01$ & 172.11 & $<0.01$ & 31.32 & $<0.01$ \\
\hline
\end{tabular}


Table 3. Results of two-way general linear models testing for significant differences in lignin content and composition of switchgrass stem tissue in response to biocides and $\mathrm{N}$ fertilizer application. Significant effects $(\mathrm{p}<0.05)$ are in bold.

\begin{tabular}{|c|c|c|c|c|c|c|c|c|c|c|}
\hline \multirow[t]{2}{*}{ Source of Variation } & \multicolumn{2}{|c|}{$\begin{array}{l}\text { Total lignin } \\
(u g / m l)\end{array}$} & \multicolumn{2}{|c|}{$\begin{array}{l}\text { Syringyl unit }(S) \\
(u g / m l)\end{array}$} & \multicolumn{2}{|c|}{$\begin{array}{l}\text { Guaiacyl unit } \\
\text { (G) } \\
(\text { ug/ml) }\end{array}$} & \multicolumn{2}{|c|}{$\begin{array}{l}\text { p-hydroxyphenyl } \\
\text { unit } \\
\text { (H) } \\
(\text { ug/ml })\end{array}$} & \multicolumn{2}{|l|}{$S: G$} \\
\hline & $\mathrm{F}$ & $\mathrm{P}$ & $F$ & $\mathrm{P}$ & $\mathrm{F}$ & $\mathrm{P}$ & $\mathrm{F}$ & $\mathrm{P}$ & $\mathrm{F}$ & $\mathrm{P}$ \\
\hline N-Fertilizer & 4.24 & 0.04 & 7.34 & $<0.01$ & 0.64 & 0.42 & 1.78 & 0.18 & 4.79 & $\mathbf{0 . 0 3}$ \\
\hline Biocides & 1.46 & 0.22 & 4.27 & $<0.01$ & 0.79 & 0.49 & 0.35 & 0.78 & 3.80 & 0.01 \\
\hline $\begin{array}{l}\text { N-Fertilizer } \mathrm{x} \\
\text { Biocides }\end{array}$ & 0.21 & 0.88 & 1.36 & 0.25 & 0.75 & 0.52 & 1.77 & 0.15 & 2.30 & 0.80 \\
\hline Cultivar & 0.22 & 0.63 & 6.14 & 0.01 & 5.84 & 0.01 & 13.40 & $<0.01$ & 14.42 & $<0.01$ \\
\hline Season & 32.40 & $<0.01$ & 12.55 & $<0.01$ & 24.27 & $<0.01$ & 2.07 & 0.15 & 0.27 & 0.59 \\
\hline
\end{tabular}


Table 4. Results of two-way general linear models testing for significant differences in lignin content and composition of switchgrass root tissues in response to biocides and N fertilizer application. Significant effects $(\mathrm{p}<0.05)$ are in bold.

\begin{tabular}{|c|c|c|c|c|c|c|c|c|c|c|}
\hline \multirow[t]{2}{*}{ Source of Variation } & \multicolumn{2}{|c|}{$\begin{array}{l}\text { Total lignin } \\
(u g / m l)\end{array}$} & \multicolumn{2}{|c|}{$\begin{array}{l}\text { Syringyl unit }(S) \\
(u g / m l)\end{array}$} & \multicolumn{2}{|c|}{$\begin{array}{l}\text { Guaiacyl unit } \\
\text { (G) } \\
(\text { ug/ml })\end{array}$} & \multicolumn{2}{|c|}{$\begin{array}{l}\text { p-hydroxyphenyl } \\
\text { unit } \\
\text { (H) } \\
\text { (ug/ml) }\end{array}$} & \multicolumn{2}{|l|}{$S: G$} \\
\hline & $\mathrm{F}$ & $\mathrm{P}$ & $\mathrm{F}$ & $\mathrm{P}$ & $\mathrm{F}$ & $\mathrm{P}$ & $\mathrm{F}$ & $\mathrm{P}$ & $\mathrm{F}$ & $\mathrm{P}$ \\
\hline N-Fertilizer & 1.74 & 0.18 & 0.80 & 0.37 & 1.86 & 0.17 & 8.36 & $<0.01$ & 0.00 & 0.95 \\
\hline Biocides & 0.83 & 0.47 & 0.45 & 0.71 & 1.25 & 0.29 & 0.44 & 0.71 & 1.33 & 0.26 \\
\hline $\begin{array}{l}\text { N-Fertilizer x } \\
\text { Biocides }\end{array}$ & 1.51 & 0.21 & 1.02 & 0.38 & 1.61 & 0.19 & 1.93 & 0.12 & 0.27 & 0.84 \\
\hline Cultivar & 0.02 & 0.87 & 0.01 & 0.91 & 0.08 & 0.77 & 0.03 & 0.84 & 0.02 & 0.88 \\
\hline Season & 74.02 & $<0.01$ & 110.27 & $<0.01$ & 46.33 & $<0.01$ & 20.50 & $<0.01$ & 81.01 & $<0.01$ \\
\hline
\end{tabular}




\section{Figure Legends}

Figure 4: Adjusted mean of leaf p-hydroxyphenyl $(\mathrm{H})$ unit response to biocide and $\mathrm{N}$ fertilizer application. Statistically different average values found between biocide treatments with Tukey's HSD $(p<0.05)$ test are indicated by a horizontal bar with an asterisk above. Vertical bars show the standard error of the adjusted mean value. Open bars are unfertilized treatments, black bars are $\mathrm{N}$ fertilized treatments. 'Both' denotes combined fungicide and nematicide treatment. Main biocide effects were significant at $\mathrm{p}=0.03$.

Figure 5: Adjusted means of stem lignin responses: (a) total lignin, (b) S unit (c) $\mathrm{S}: \mathrm{G}$ to biocide and $\mathrm{N}$ fertilizer application. Statistically different average values between biocide treatments found with Tukey's HSD $(p<0.05)$ tests are indicated by horizontal bars with asterisks above. Vertical bars show the standard errors of the adjusted mean values. Open bars are unfertilized treatments, black bars are $\mathrm{N}$ fertilized treatments. 'Both' denotes combined fungicide and nematicide treatment.

Figure 6: Adjusted mean of root p-hydroxyphenyl $(\mathrm{H})$ unit response to biocide and $\mathrm{N}$ fertilizer application. Vertical bars show the standard error of the adjusted mean value. Open bars are unfertilized treatments, black bars are $\mathrm{N}$ fertilized treatments. 'Both' denotes combined fungicide and nematicide treatment. Main fertilizer effects were significant at $\mathrm{p}<0.01$. 
Figure 4

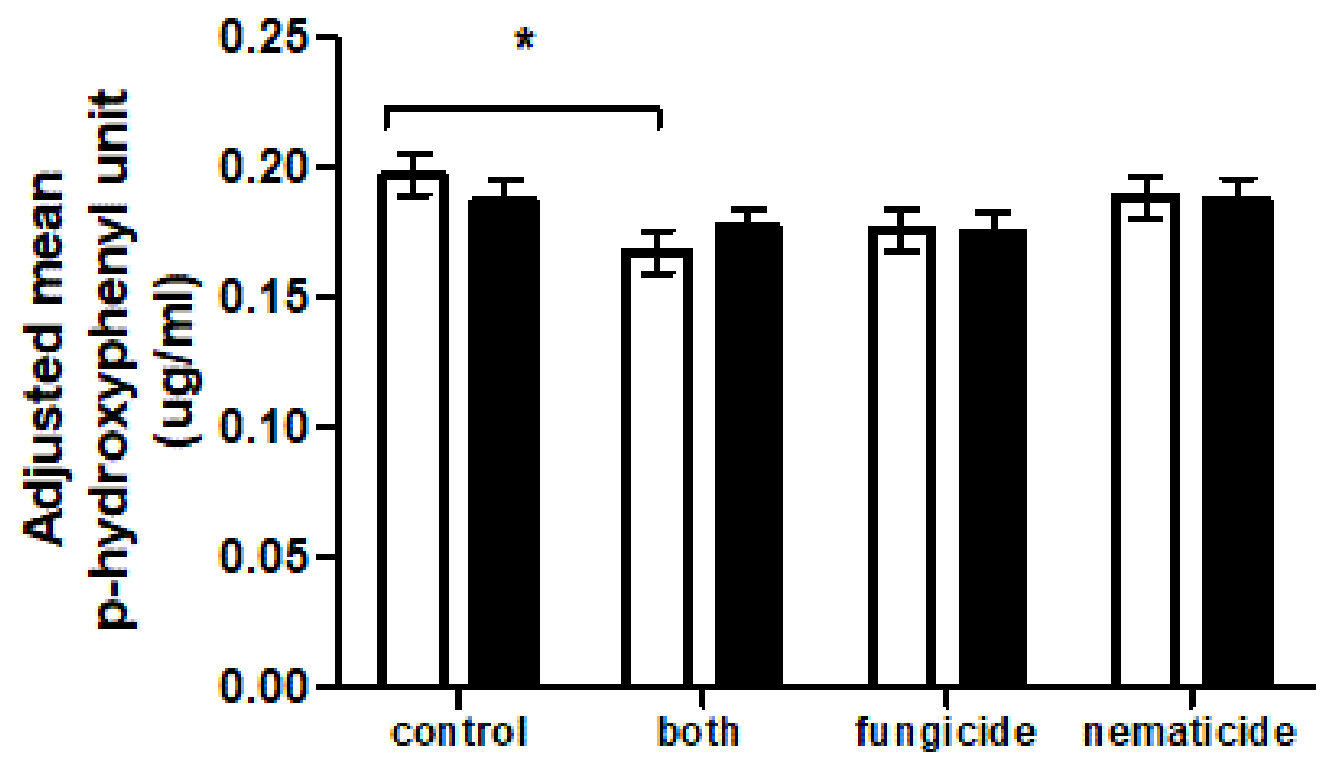


Figure 5
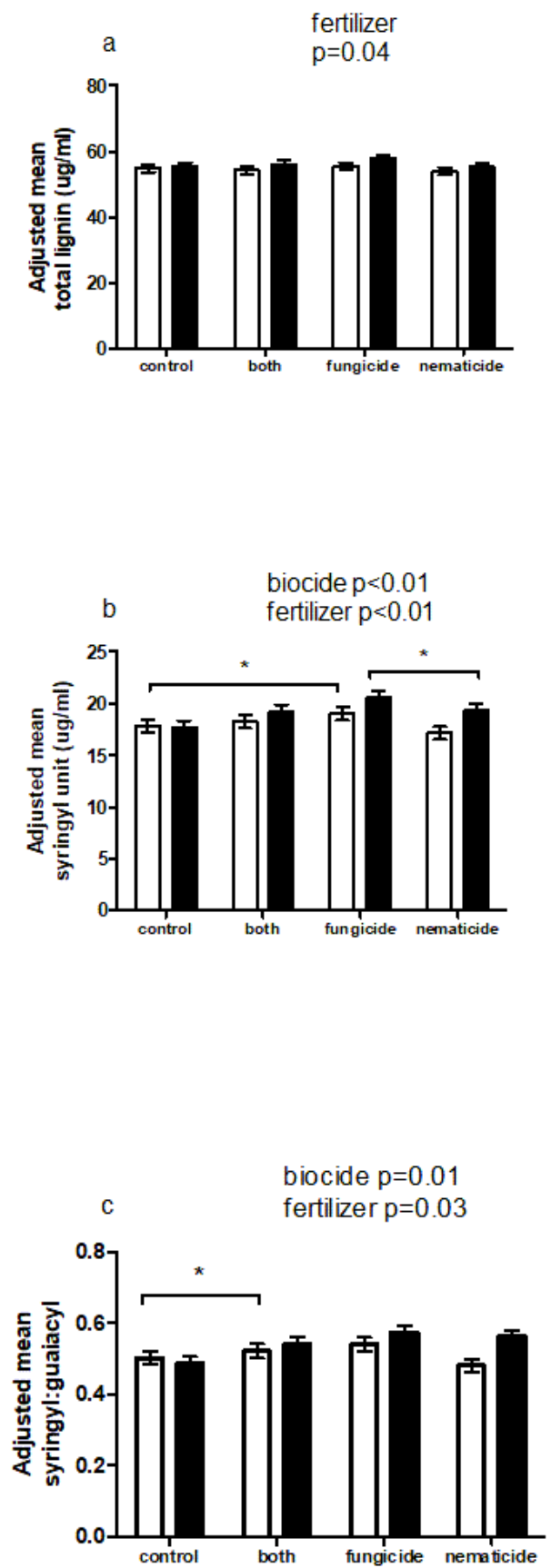
Figure 6

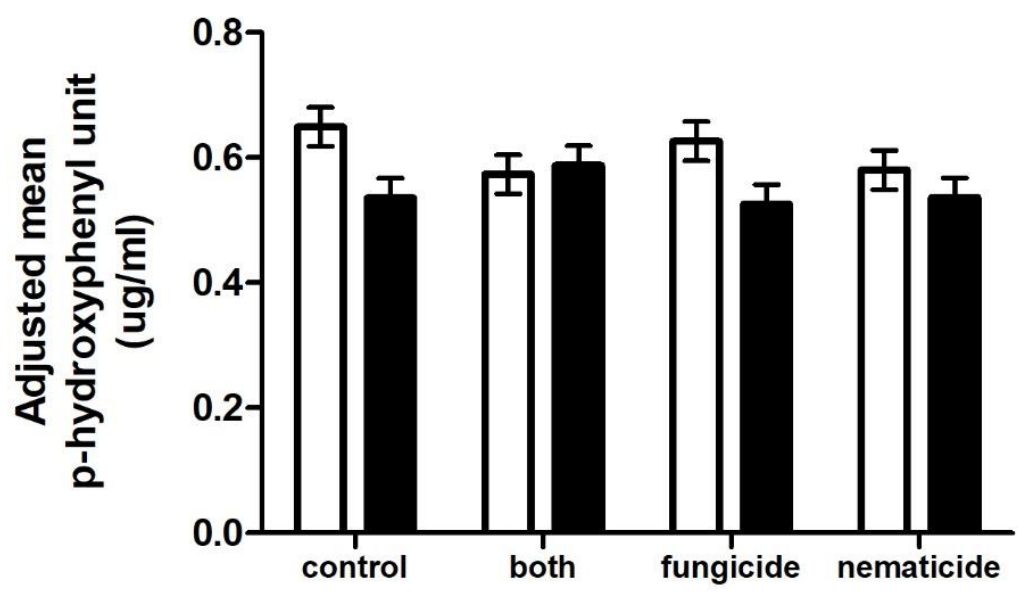




\title{
CHAPTER IV
}

\section{ARBUSCULAR MYCORRHIZAL FUNGI BENEFIT SWITCHGRASS GROWTH}

\section{ACROSS A SOIL MOISTURE GRADIENT}

\begin{abstract}
SUMMARY
Arbuscular mycorrhizal (AM) fungi form one of the most ubiquitous symbioses with terrestrial plants and are widely known for their benefits such as water and nutrient transfer to host plants and defense against diseases and herbivores. They are particularly important under adverse environmental conditions like drought, where they help their hosts to acquire tightly bound water from the soil. However, the functioning of plantmycorrhizal fungal symbiosis can span a gradient from mutualism to parasitism. In this study, we investigated the effects of AM fungi on growth, plant cell wall chemistry, and root architecture of a biofuel crop Panicum virgatum (switchgrass) along a drought intensity gradient. This study is also the first to document changes in plant cell wall chemistry and root architecture along a soil moisture continuum. We predicted that AMF would provide maximum growth benefit to the plant under intermediate moisture stress and minimum/no benefit under very high and very low soil moisture. Overall, we found an increase in root biomass, average root diameter, number of tillers, number of leaves, and amount of cellulose and hemicellulose in response to root colonization by AM fungi.
\end{abstract}


AM fungi also increased aboveground biomass, root diameter, root surface area, total root length, root volume and number of root forks, but only under low soil moisture conditions, indicating a reduction in benefits of AMF associations under high soil moisture.

\section{INTRODUCTION}

Arbuscular mycorrhizal (AM) fungi are widespread plant symbionts, forming associations with $80 \%$ of all terrestrial plant species (Smith and Read 2010). AM fungi primarily help their host plants with nutrient and water uptake, while relying on their host for carbon (Smith and Read 2010). While AM fungi have shown positive effects on many aboveground plant growth measures such as biomass, flowering, yield, height, and tillering under drought stress (Asrar et al. 2012; Marulanda et al. 2009; Secilia and Bagyaraj 1992; Wu and Xia 2006), in very dry or very wet conditions the AM fungi-plant symbiosis may shift to become parasitic (Johnson et al. 1997).

While the definition of 'parasitism' is a debated topic when addressing mycorrhizal functioning along a gradient (Smith and Smith 2013), here we restrict the meaning to growth outcomes of AM fungal-plant symbiosis. $20-40 \%$ of the photosynthates assimilated by plants are lost to fungal symbionts (Jakobsen and Rosendahl 1990) and so AM fungi can become parasitic when the net cost of maintaining the fungal partner exceeds the benefits. Demonstration of 'mycorrhizal parasitism' has been done almost explicitly under low light or high nutrient conditions (Johnson et al. 1997; Olsson et al. 2010) and much less is known about AM fungi-plant functioning along a continuum of moisture stress. However, we expect that benefits of AM fungi to plants will be minimized in high soil moisture conditions as plant will be able to access 
adequate water on their own, while the energetic costs of the symbiosis will be overwhelming for plant hosts at very low soil moisture conditions, resulting in maximum benefits at intermediate soil moisture conditions (Fig. 7).

AM fungi are beneficial to plants under stressful environmental conditions such as drought by having positive effects on plant water relations (Augé 2001). They may alleviate moisture stress in the plants via increased water uptake (Al-Karaki and AlRaddad 1997), improved nutrition of the host (Fitter 1988), enhanced root longevity (Eissenstat et al. 2000) or by altering physiological or morphological traits (Augé et al. 1986; Davies Jr et al. 1993; Drüge and Schonbeck 1993). For example, AM fungi can alter root morphology by stimulating growth of fine root hairs, and increasing root length and root diameter under drought conditions (Hetrick et al. 1988; Zou et al. 2017). However, findings from previous studies are inconsistent for different plants and AM fungal species, as AM fungi are reported to both increase and decrease root length, surface area, volume, and branching in response to drought (Hodge et al. 2009; Oláh et al. 2005; Yao et al. 2009). Either way, any significant alteration of root architectural traits can have potential consequences for a plant's ability to take up water and nutrients under drought conditions since enhancement of traits such as root length and diameter can provide higher surface area and facilitate the absorption of more water and nutrients (Vincent et al. 2017).

Plants generally invest in belowground biomass under drought conditions (Achten et al. 2010; Eziz et al. 2017). A comprehensive meta-analysis of studies reporting AM fungal impacts on root/shoot (R/S) allometric partitioning demonstrated an overall increase in $\mathrm{R} / \mathrm{S}$ ratios in plants grown under a variety of abiotic stresses including 
drought, indicating that plants invest more in roots in the presence of such stresses (Veresoglou et al. 2012). Differential allocation of resources both above- and belowground may affect a plant's ability to tolerate drought especially via the effects on root traits.

This shift in the functioning of AM fungi-plant symbioses may have important implications for agricultural systems, where drought is an important environmental stressor with direct effects on crop yield (Lipiec et al. 2013). For perennial bioenergy crops such as switchgrass (Panicum virgatum) that form strong associations with AM fungi (Clark et al. 1999; Emery et al. 2017), any shifts in the net effects of symbioses on crop yield may have significant economic consequences. Drought alone can cause up to a $35 \%$ increase in the cost of biofuel production from lignocellulosic biofuel crops such as switchgrass due to reduced aboveground biomass production (Morrow III et al. 2014), and it is unclear whether AM fungi mitigate or contribute to this decline. Additionally, other economically important plant traits such as plant cell wall composition, can also be influenced by AM fungi and also strongly respond to the drought stress. Cellulose, hemicellulose, and lignin concentrations in plant tissues are important considerations for biomass processing for bioenergy production (Rubin 2008) and can be influenced by both AM fungi and drought. Previous studies have documented varied effects of drought on cell wall composition, including no effects/increase in cellulose, an increase in hemicellulose and varied effects on lignin (Chen et al. 2018; Fan et al. 2006; Zwiazek 1991). While specific mechanisms controlling effects of AM fungi on cell well composition are unclear, AM fungi penetrate the root cortex and in doing so can prime salicylic acid pathway which is widely known to induce lignification (Allen 1991; He and 
Wolyn 2005; Zhang et al. 2013). AM fungi are also associated with increases in plant lignin, potentially conferring mechanical reinforcement against pathogenic attack (Morandi 1996). However, they can also decrease plant lignin in drought by minimizing water stress (Lee et al. 2012). In the face of global climate change, understanding effects of AM fungi symbioses in plants becomes ever more important as the severity and frequency of drought is expected to be more pronounced (Carnicer et al. 2011; Meehl and Tebaldi 2004).

In this study, we investigated the effects of AM fungi on switchgrass above- and belowground growth along a drought intensity gradient. We predicted that 1) AM fungi would provide maximum aboveground growth benefit at intermediate drought stress, with reduced benefits or even parasitism at very low or very high soil moisture levels. We predicted that 2) the main benefits of AM fungi to host plants would be increased access to soil water potentially by increasing root length and surface area, which would result in increased aboveground biomass at intermediate soil moisture levels. We also expected that 3) AM fungi would increase plant allocation to belowground biomass at intermediate soil moisture levels. We further hypothesized that 4) AM fungi would increase switchgrass root cellulose and hemicellulose content potentially by altering cell wall metabolism (Rich et al. 2014; Vorwerk et al. 2004). They would also 5) increase belowground lignin content since they directly interact with plant roots and can potentially induce lignification as a defense response against fungal penetration (Bennett et al. 2015). We also predicted that 6) AM fungi would decrease aboveground lignin content under high drought to provide osmo-amelioration against drought by reducing lignin (Lee et al. 2012). We also expected that 7) changes in cell wall composition will be 
most apparent belowground where AM fungi directly interact with host roots. To our knowledge, no studies have documented AM fungi effects on plant root architecture and cell wall composition along a gradient of drought.

\section{MATERIALS AND METHODS}

\section{Experiment design}

We designed a two-factor growth chamber experiment to test for effects of AM fungi on switchgrass growth across a soil moisture gradient. Switchgrass seeds (Cave-InRock cultivar, source: Ernst Seeds, PA; 99\% PLS) were surface sterilized in 10\% bleach solution for $5 \mathrm{~min}$, then rinsed with tap water for $5 \mathrm{~min}$, and stored at $4{ }^{\circ} \mathrm{C}$ for 24 hours until they could be germinated in petri dishes containing filter paper and vermiculite. Fourteen days after germination, seedlings were transplanted to pots for the experiment.

We filled ninety $10.2 \mathrm{~cm} \times 30.5 \mathrm{~cm}$ pots (Treepots, Stewe and Sons, OR) with a 4:1 mixture of play sand (Sakrete of North America, LLC, Sakrete) and sterilized (double autoclaved) field soil collected from Kellogg Biological Station-Long Term Ecological Research Site. For the AM fungi treatment (+AM fungi), we used pure cultures of the AM fungi species Claroideoglomus etunicatum (Accession NE108A from INVAM, Morgantown, West Virginia), a species that is commonly found in grasslands throughout the world and a known associate with switchgrass (Clark et al. 2005). This particular species of AM fungi is also known to affect host plant water relations (Augé 2001). $5 \mathrm{~g}$ of the AM fungal inocula (consisting of a mixture of sterile sand, soil, root fragments, AM fungal hyphae and spores) was mixed with $5 \mathrm{~g}$ of play sand and layered on top of the pots before the 14-day-old seedlings were transplanted. $5 \mathrm{~g}$ of INVAM media without AM 
fungal hyphae and spores mixed with $5 \mathrm{~g}$ play sand was added in the other half of the pots (AM fungi-).

The drought treatment included 5 levels based on the water holding capacity (WHC) of the soil (i.e. 100\% WHC, 75\% WHC, 50\% WHC, 35\% WHC and 20\% WHC). Water holding capacity was determined gravimetrically (Earl 2003). To do this, a subset of filled pots was fully saturated with water and their top covered by parafilm. The pots were left in a growth chamber for 48 hours to allow drainage of water under gravity. After 48 hours, soil from the top, middle and bottom of the pot was taken, weighed, ovendried, and reweighed. Soil moisture content at water holding capacity was then determined by calculating the difference between initial soil weight and oven-dried soil weight. After seedlings were transplanted, soil moisture was recorded daily using a moisture meter (Campbell Scientific 2020). When moisture content dropped, an appropriate amount of water was added to bring it back to its assigned treatment level. Plants were exposed to their respective soil moisture \% continuously throughout the experiment. Plants at $20 \%$ WHC exhibited slight curling of leaves indicating stress.

After seedlings were transplanted to the pots, they were moved to an environmental growth chamber $\left(25-27^{\circ} \mathrm{C}\right.$ daytime temperature, $11-14^{\circ} \mathrm{C}$ nighttime temperature and $14-16 \mathrm{~h}$ light $/ 8-10 \mathrm{~h}$ dark cycles). The 10 treatment combinations (2 AM fungi x 5 Drought) were replicated 9 times for the total of 90 pots. The pots were randomly rearranged once every week to control for variation within the growth chamber.

\section{Data Collection}


After 90 days, all plants were harvested from the experiment. The number of leaves, tillers, etc. were recorded and plant aboveground and belowground biomass were separated, oven dried at $60{ }^{\circ} \mathrm{C}$ and weighed.

To assess the degree of root colonization by AM fungi, five $3 \mathrm{~cm}$ fine root pieces were cut from each plant before root biomass was dried, cleared with $10 \% \mathrm{KOH}$, rinsed with water, treated with acidified water to remove $\mathrm{KOH}$, and stained with Trypan Blue (Vierheilig et al. 2005). Ten $1 \mathrm{~cm}$ pieces of roots were then mounted on microscope slides and observed under a microscope at 920x magnification (Leica Microsystems, Wetzlar, Germany). The presence and absence of infection (hyphae or arbuscules) in the roots was recorded and expressed as a percentage (Giovannetti and Mosse 1980). AMFplants had no evidence of root colonization whereas AMF+ plants had an average colonization of $67 \%$.

Before root biomass was dried, root architectural measures were taken by scanning roots using WinRhizo software (Regent Instruments, Canada). We measured total root length, root surface area, root diameter and number of root forks.

To quantify cell wall composition for both root and shoot tissues, neutral detergent fiber (NDF), acid detergent fiber (ADF) and acid detergent lignin (ADL) were determined by the sequential method (Van Soest and Robertson 1979) using an $\mathrm{ANKOM}^{200}$ fiber analyzer (Macedon, NY) by following ANKOM ${ }^{200}$ Technology's (ANKOM Technology Corp., Fairport, NY, USA) analytical procedure (ANKOM ${ }^{200}$ 2016). In brief, $0.5 \mathrm{~g}$ oven dried plant samples were ground and sieved through $1 \mathrm{~mm}$ screen using a Thomas Wiley Mill (Thomas Scientific, Swedesboro, NJ, USA). The sample was then digested in the fiber analyzer using alpha amylase and sodium sulfite to 
calculate NDF. The sample was subsequently subjected to digestion by cetyl trimethylammonium bromide (CTAB) and $1 \mathrm{~N}$ sulfuric acid to calculate ADF. The sample was finally digested in $72 \%$ sulfuric acid to calculate ADL. The relative percentage of the cell wall components (cellulose, hemicellulose and lignin) were calculated using the component concentrations expressed on an oven-dry weight basis (Jung and Vogel 1992). Lignin was expressed as percent ADL on as-received basis whereas hemicellulose and cellulose were calculated as NDF minus ADF and ADF-ADL respectively (Jung and Vogel 1992).

Statistical analyses

Response variables, including above- and belowground biomass, tillers, leaves and R/S ratio were analyzed using 2- factor general linear models, with AM fungi and drought as main factors, including all interaction terms. Model fit was determined with chi-square tests. Shapiro-Wilk and Levene's tests were used to check normality and homogeneity of variances, respectively. All statistical analysis was done in R (R Core Team 2017).

\section{RESULTS}

AM fungi and drought had interactive effects on aboveground biomass of switchgrass, but not in the way we predicted. AM fungi increased shoot dry biomass under the driest conditions, but the effect decreased as the soil moisture increased. In contrast, mycorrhizal plants had 32\% more tillers and 37\% more leaves per plant, independent of soil moisture (Table 5, Fig. 8) 
Belowground, mycorrhizal plants had 52\% more root dry biomass than nonmycorrhizal plants, independent of soil moisture (Table 6, Fig. 9). However, AM fungi and drought had interactive effects on total root length, root surface area, average root diameter, root volume, and number of root forks (Table 6, Fig. 9). All these measures were higher in mycorrhizal plants under the driest conditions and continued to decline with increasing soil moisture except for average root diameter (Table 6, Fig. 9).

Aboveground cell wall composition did not respond to any of the treatments whereas root cell wall composition responded to AM fungi treatment only (Table 7). Root colonization by AM fungi increased root cellulose by about $27 \%$ and root hemicellulose by $32 \%$ (Table 7, Fig 11a-b). Lignin did not respond to any of the treatments (Table 7, Fig. 11c)

\section{DISCUSSION}

Plants respond to mycorrhizal colonization in a continuum from mutualism to parasitism as a function of abiotic stress or resource availability (Johnson et al. 1997). In our study, most of the plant responses depended on the resource gradient. We found that soil moisture influenced the relative benefits of AM fungi in host plants, but not in the ways we predicted. The greatest benefits of AM fungi were at the experiment's lowest soil moisture levels, and these benefits often disappeared at the experiment's high soil moisture levels. The continued decline of benefits provided by AM fungi can be explained by a potential shift in cost/benefit ratio involved in the symbiosis. The cost/benefit ratio in a symbiotic relationship can shift if one partner can access resources cheaply from the environment (Allen 1991; Paracer and Ahmadjian 2000). On the other hand, under severe drought, the cost of maintaining mycorrhizal fungi can become so 
high that it can potentially outweigh the benefits provided by the fungi. However, in this study, AM fungi were quite beneficial to switchgrass, especially at the experiment's lowest soil moisture conditions. This supports the idea that the benefits of AM fungi are not needed in high-resource conditions, and also that the energetic costs to the plant are not too high, even at very low soil moisture conditions when plants should be most resource-stressed. One limitation in our soil moisture manipulation is the determination of stress. Stress was determined visually only. Leaf curling at $20 \%$ WHC indicated that plants were stressed at the corresponding moisture level. We did not visually observe any stress in the plants under full water holding capacity.

Our finding of higher shoot mass of mycorrhizal plants under soil moisture deficit is consistent with findings from previous studies (Jayne and Quigley 2014). Although drought can reduce tillering (Korte and Chu 1983), we did not observe any drought effects on switchgrass tillering. However, mycorrhizal treatment enhanced tillering in our study which is also consistent with reports from previous studies (Ellis et al. 1985). Our results suggest that AM fungi are beneficial or neutral to plant hosts over a wide range of soil moisture conditions. Mycorrhizal parasitism is more evident in facultatively mycotrophic hosts when resource limitation is removed (Johnson et al. 1997). Switchgrass forms a tight association with AM fungi and the dependence to AM fungi might still be important even when resource limitation is removed.

Belowground, AM fungi always increased root biomass, independent of soil moisture, but had mixed effects on root architectural traits depending on soil moisture. Mycorrhizal plants are more water efficient than non-mycorrhizal plants (Al-Karaki 1998) which can explain the enhanced root growth of mycorrhizal plants under a range of 
soil conditions. Alleviation of resource limitation can result in a decline in R/S ratio in mycorrhizal plants (Veresoglou et al. 2012). However, multiple regulators of R/S ratio such as experimental duration, AM fungal and plant species identity, or pot volume might be interacting to result in no net effects on the R/S ratio in this study (Veresoglou et al. 2012).

Mycorrhizal fungi can functionally increase the surface area of plant fine roots more than a hundred-fold (Perry 1982). At lower soil moisture, we observed that AM fungi increased plant root length, volume, surface area, root diameter, and number of root forks, which could explain the increases in both root and shoot biomass. However, these root architecture changes were not seen at higher soil moisture. This may be due to a lack of benefits provided to plants when resources like water are freely available. Alternatively, under high soil moisture conditions, nutrient acquisition ability of plant roots can be impaired due to a series of physiological changes like decreases in tissue water potential and turgor, which can subsequently result in decreased permeability of roots (Alam 1999). Regardless of mycorrhizal association, high soil moisture can also result in soil nitrogen leaching, as reported in pot studies, that can directly and negatively impact plant aboveground and belowground growth measures (Alam 1999).

Contrary to our expectation, lignin did not respond to any of the treatment in our study, though root cellulose and hemicellulose increased in the mycorrhizal plants. AM fungal colonization is known to activate genes which can potentially result in biosynthesis of cellulose and hemicellulose (Chen et al. 2018). AM fungal colonization also can increase the expression of a group of enzymes called glycosyltransferases (GTs) which are primarily involved in cell wall metabolism including cellulose and 
hemicellulose biosynthesis and assembly (Detering et al. 2005; Fiorilli et al. 2009). For example, a study on vetiver grass demonstrated an increase in cellulose and hemicellulose upon AM fungal colonization which appears to be a systemic response rather than a local response as the increase was reported in root stele region that was devoid of the fungal structures like hyphae or arbuscules (Chen et al. 2018). However, the lack of aboveground responses indicate that AMF had mostly local effects on cell wall chemistry.

The lack of response in cell wall lignin was surprising, as AM fungi can induce lignification by priming the salicylic acid pathway (Bennett et al. 2015; He and Wolyn 2005; Zhang et al. 2013), and so we predicted an increase in root lignin content. Additionally, the stimulation of phenylpropanoid pathway, a common pathway of synthesis of building blocks of lignin, by AM fungal symbiosis, is a widely observed phenomenon (Baslam et al. 2011; Castellanos-Morales et al. 2010; Ganz et al. 2002). The lack of lignin response in our study could be due to less lignification in early stages of plant development as our plants were grown for a relatively short duration (Jung and Vogel 1992).

We predicted the mycorrhizal symbiosis would provide maximum growth benefits at an intermediate level of drought and would potentially harm plants at very high or very low soil moisture conditions. Contrary to our predictions, AM fungi were always beneficial or neutral, with the strongest benefits seen at the experiment's lowest soil moisture, possibly due to increases in beneficial root architecture traits used to forage for water. It is possible that the lack of decline in AM fungi benefits at low soil moisture may be due to the cultivar of switchgrass used in this experiment, which is an upland 
cultivar primarily developed for winter hardiness and drought resistance (Alderson and Sharp 1994). The ability of this cultivar to tolerate drought and to form strong mycorrhizal associations could explain why the mycorrhizal symbiosis was still beneficial under very dry soil conditions. The results of this study indicate that growers need not be concerned about potential energetic costs of AM fungi in switchgrass grown for bioenergy feedstock, especially when upland drought-hardy cultivars are grown. Instead, the results suggest that AM fungi will benefit switchgrass, especially during the establishment phase.

One caveat to this study is that we used only one AM fungal species, whereas switchgrass can form simultaneous association with multiple AM fungal species and the outcome of such plant-AM fungal interactions along a moisture gradient can be species specific (Anderson et al. 1984). Future studies should focus on specific molecular and physiological mechanisms by which AM fungi and drought interact to affect plant growth and cell wall composition. Finally, a focus to understand the net outcome of a plant's interaction with a suite of biotic factors, mutualists and antagonists alike, should be made for more comprehensive understanding of plant-mycorrhizal symbiosis along an environmental stress gradient. 
Table 5. Results of two-way general linear models testing for significant differences in aboveground measures of switchgrass in response to AM fungi and drought. Significant effects $(\mathrm{p}<0.05)$ are in bold.

\begin{tabular}{|c|c|c|c|c|c|c|c|c|}
\hline \multirow[t]{2}{*}{$\begin{array}{l}\text { Source of } \\
\text { Variation }\end{array}$} & \multicolumn{2}{|c|}{$\begin{array}{l}\text { Shoot } \\
\text { biomass } \\
\text { (g) }\end{array}$} & \multicolumn{2}{|c|}{$\begin{array}{l}\text { Number of } \\
\text { tillers }\end{array}$} & \multicolumn{2}{|c|}{$\begin{array}{l}\text { Number of } \\
\text { leaves }\end{array}$} & \multicolumn{2}{|c|}{$\begin{array}{l}\text { Total tiller } \\
\text { length }\end{array}$} \\
\hline & $\mathrm{F}$ & $\mathrm{P}$ & $\mathrm{F}$ & $\mathrm{P}$ & $\mathrm{F}$ & $P$ & $\mathrm{~F}$ & $\mathrm{P}$ \\
\hline AM fungi & 2.34 & 0.13 & $\begin{array}{l}11.1 \\
4\end{array}$ & $\begin{array}{l}<0.0 \\
1\end{array}$ & 5.1 & 0.02 & 0.57 & 0.45 \\
\hline Drought & 1.81 & 0.13 & 1.73 & 0.15 & 1.35 & 0.26 & 0.42 & 0.82 \\
\hline $\begin{array}{l}\text { AM fungi } x \\
\text { Drought }\end{array}$ & 2.92 & 0.05 & 2.27 & 0.07 & 1.03 & 0.39 & 1.00 & 0.41 \\
\hline
\end{tabular}


Table 6. Results of two-way general linear models testing for significant differences in belowground measures of switchgrass

in response to AM fungi and drought. Significant effects $(\mathrm{p}<0.05)$ are in bold.

\begin{tabular}{|c|c|c|c|c|c|c|c|c|c|c|c|c|c|c|}
\hline \multirow[t]{2}{*}{$\begin{array}{l}\text { Source of } \\
\text { Variation }\end{array}$} & \multicolumn{2}{|c|}{$\begin{array}{l}\text { Root biomass } \\
(\mathrm{g})\end{array}$} & \multicolumn{2}{|c|}{$\begin{array}{l}\text { Root Surface } \\
\text { area }\left(\mathrm{cm}^{2}\right)\end{array}$} & \multicolumn{2}{|c|}{$\begin{array}{l}\text { Average root } \\
\text { diameter }\end{array}$} & \multicolumn{2}{|c|}{$\begin{array}{l}\text { Root volume } \\
\left(\mathrm{cm}^{3}\right)\end{array}$} & \multicolumn{2}{|c|}{$\begin{array}{l}\text { Root } \\
\text { length }\end{array}$} & \multicolumn{2}{|c|}{$\begin{array}{l}\text { Root/Shoot } \\
\text { ratio }\end{array}$} & \multicolumn{2}{|c|}{$\begin{array}{l}\text { Number of } \\
\text { forks }\end{array}$} \\
\hline & $\mathrm{F}$ & $\mathrm{P}$ & $\mathrm{F}$ & $\mathrm{P}$ & $\mathrm{F}$ & $\mathrm{P}$ & $\mathrm{F}$ & $\mathrm{P}$ & $\mathrm{F}$ & $\mathrm{P}$ & $\mathrm{F}$ & $\mathrm{P}$ & $\mathrm{F}$ & $\mathrm{P}$ \\
\hline AM fungi & 4.59 & 0.03 & 0.65 & 0.42 & $\begin{array}{l}19.4 \\
1\end{array}$ & $<0.01$ & 3.00 & 0.08 & 0.34 & 0.55 & 0.06 & 0.79 & 0.62 & 0.43 \\
\hline Drought & 0.31 & 0.86 & 1.06 & 0.38 & 2.64 & 0.04 & 1.83 & 0.13 & 0.68 & 0.60 & 1.12 & 0.35 & 1.49 & 0.21 \\
\hline $\begin{array}{l}\text { AM fungi } x \\
\text { Drought }\end{array}$ & 0.47 & 0.75 & 4.17 & $<0.01$ & 6.29 & $<0.01$ & 5.791 & $<0.01$ & 3.47 & 0.01 & 1.97 & 0.11 & 4.37 & $<0.01$ \\
\hline
\end{tabular}


Table 7. Results of two-way general linear models testing for significant differences in root cell wall chemistry of switchgrass in response to AM fungi and drought. Significant effects $(\mathrm{p}<0.05)$ are in bold.

\begin{tabular}{|c|c|c|c|c|c|c|c|c|c|c|c|c|}
\hline \multirow{3}{*}{$\begin{array}{l}\text { Source of } \\
\text { Variation }\end{array}$} & \multicolumn{6}{|c|}{ Stem } & & & \multicolumn{4}{|c|}{ Root } \\
\hline & \multicolumn{2}{|c|}{$\begin{array}{l}\text { Cellulose } \\
\text { (\% dry } \\
\text { weight) }\end{array}$} & \multicolumn{2}{|c|}{$\begin{array}{l}\text { Hemicellu } \\
\text { lose } \\
\text { (\% dry } \\
\text { weight) }\end{array}$} & \multicolumn{2}{|c|}{$\begin{array}{l}\text { Lignin } \\
(\% \text { dry } \\
\text { weight) }\end{array}$} & \multicolumn{2}{|c|}{$\begin{array}{l}\text { Cellulose } \\
\text { (\% dry } \\
\text { weight) }\end{array}$} & \multicolumn{2}{|c|}{$\begin{array}{l}\text { Hemicellu } \\
\text { lose } \\
\text { (\% dry } \\
\text { weight) }\end{array}$} & \multicolumn{2}{|c|}{$\begin{array}{l}\text { Lignin } \\
\text { (\% dry } \\
\text { weight) }\end{array}$} \\
\hline & $\mathrm{F}$ & $\mathrm{P}$ & $\mathrm{F}$ & $\mathrm{P}$ & $\mathrm{F}$ & $\mathrm{P}$ & $\mathrm{F}$ & $\mathrm{P}$ & $\mathrm{F}$ & $\mathrm{P}$ & $\mathrm{F}$ & $\mathrm{P}$ \\
\hline AM fungi & $\begin{array}{l}0.0 \\
1\end{array}$ & 0.89 & $\begin{array}{l}2.3 \\
3\end{array}$ & 0.10 & $\begin{array}{l}1.1 \\
2\end{array}$ & 0.41 & $\begin{array}{l}4.1 \\
2\end{array}$ & $\begin{array}{l}0.0 \\
4\end{array}$ & $\begin{array}{l}5.6 \\
2\end{array}$ & $\begin{array}{l}0.0 \\
2\end{array}$ & $\begin{array}{l}1.2 \\
7\end{array}$ & $\begin{array}{l}0.2 \\
6\end{array}$ \\
\hline Drought & $\begin{array}{l}1.2 \\
4\end{array}$ & 0.32 & $\begin{array}{l}0.2 \\
2\end{array}$ & 0.64 & $\begin{array}{l}1.0 \\
0\end{array}$ & 0.41 & $\begin{array}{l}2.1 \\
9\end{array}$ & $\begin{array}{l}0.0 \\
8\end{array}$ & $\begin{array}{l}1.6 \\
9\end{array}$ & $\begin{array}{l}0.1 \\
6\end{array}$ & $\begin{array}{l}1.2 \\
8\end{array}$ & $\begin{array}{l}0.2 \\
8\end{array}$ \\
\hline $\begin{array}{l}\text { AM fungi } \mathrm{x} \\
\text { Drought }\end{array}$ & 1.9 & 0.15 & $\begin{array}{l}0.6 \\
4\end{array}$ & 2.84 & $\begin{array}{l}0.2 \\
7\end{array}$ & 0.89 & $\begin{array}{l}1.5 \\
6\end{array}$ & $\begin{array}{l}0.1 \\
9\end{array}$ & $\begin{array}{l}1.7 \\
2\end{array}$ & $\begin{array}{l}0.1 \\
5\end{array}$ & $\begin{array}{l}1.0 \\
2\end{array}$ & $\begin{array}{l}0.4 \\
0\end{array}$ \\
\hline
\end{tabular}




\section{Figure Legends}

Figure 7. Theoretical framework for plant-mycorrhizal symbiosis along a drought intensity gradient.

Figure 8. a) Dry shoot biomass and b) dry root biomass in response to AM fungal colonization along drought intensity gradient expressed as percent water holding capacity (\%WHC). Data points are individual replicates. Solid black line and dotted black line are trendlines for mycorrhizal and non-mycorrhizal responses, respectively.

Figure 9. Root architectural response between mycorrhizal and non-mycorrhizal plants along a drought intensity gradient expressed as \% water holding capacity (WHC). Data points are individual replicates. Solid black line and dotted black line are trendlines for mycorrhizal and non-mycorrhizal responses, respectively.

Figure 10. Root/shoot ratio response between mycorrhizal and non-mycorrhizal plants along a drought intensity gradient expressed as \% water holding capacity (WHC). Data points are individual replicates. Solid black line and dotted black line are trendlines for mycorrhizal and non-mycorrhizal responses, respectively.

Figure 11. Belowground cell wall chemistry in response to mycorrhizal colonization and drought. Data points are individual replicates. Solid black line and dotted black line are trendlines for mycorrhizal and non-mycorrhizal responses, respectively. 
Figure 7

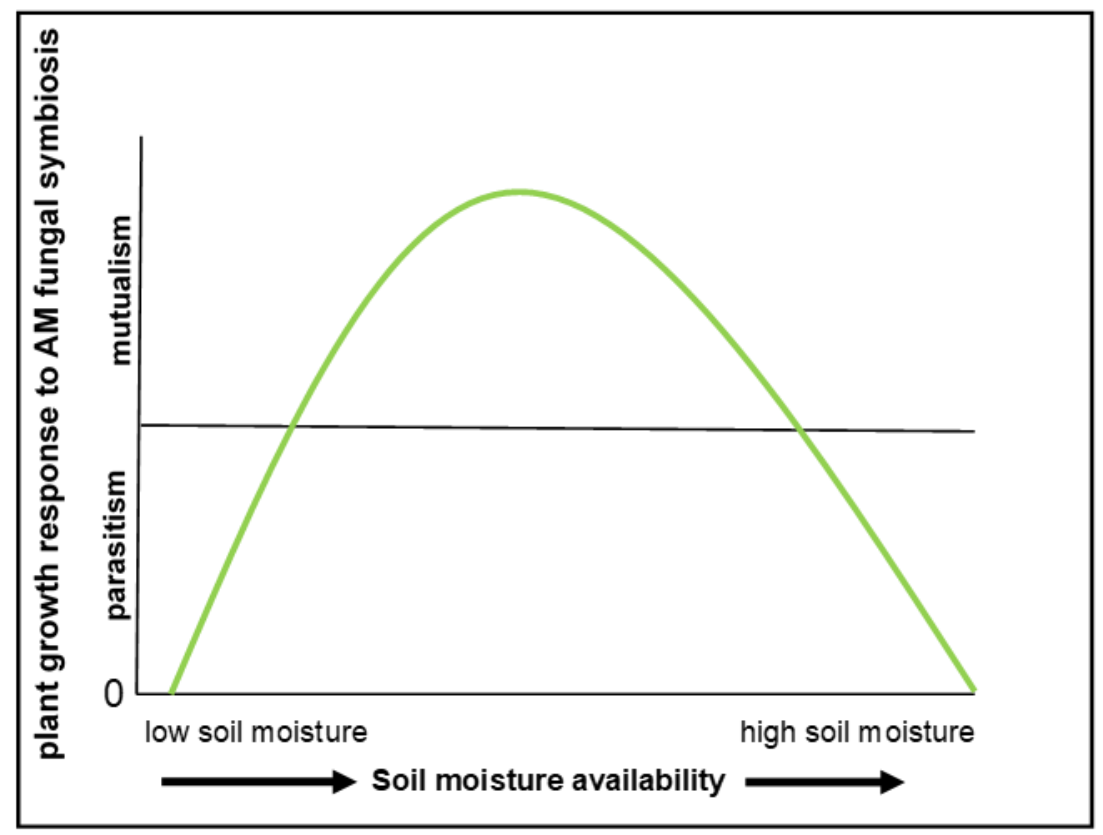


Figure 8
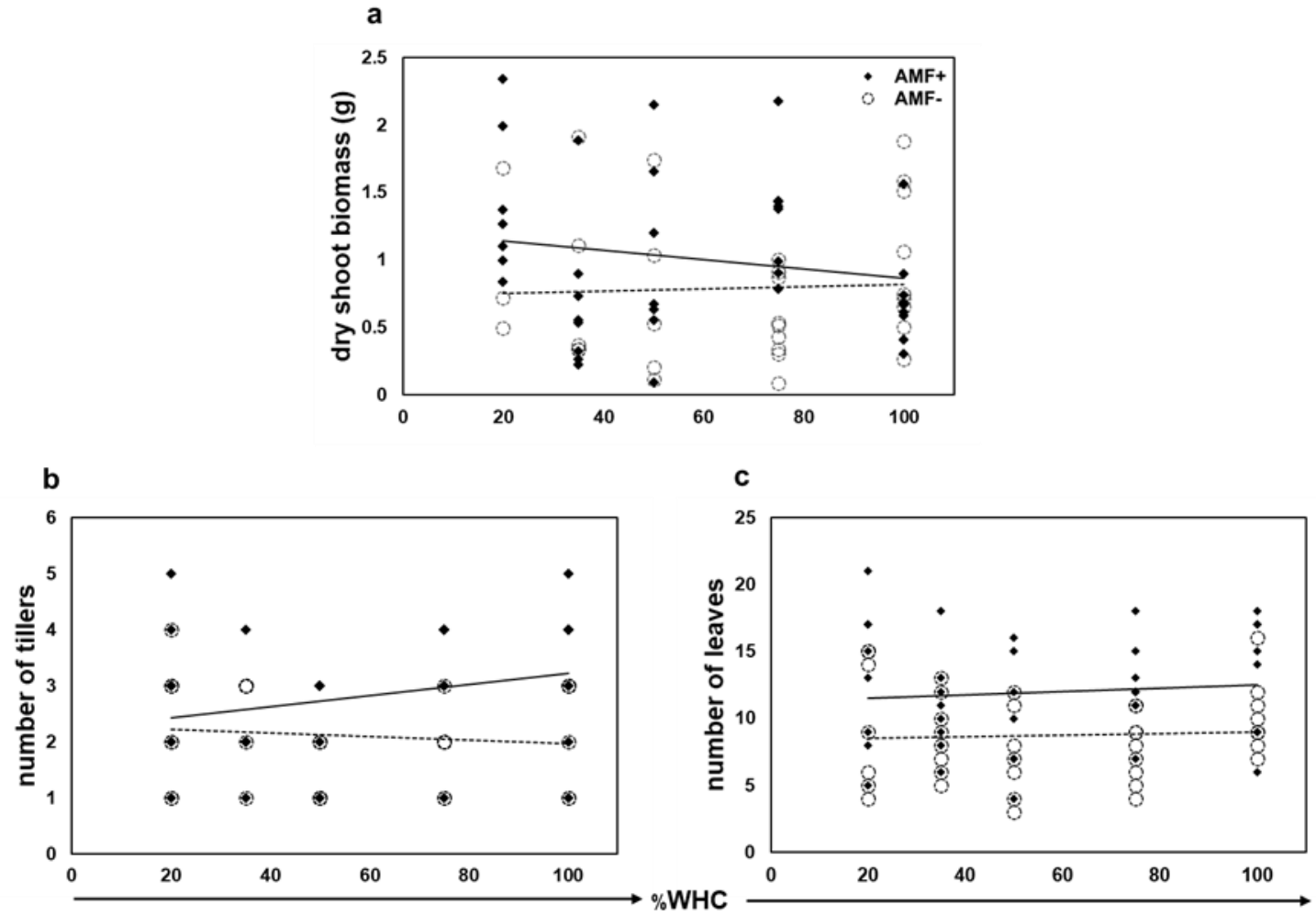
Figure 9
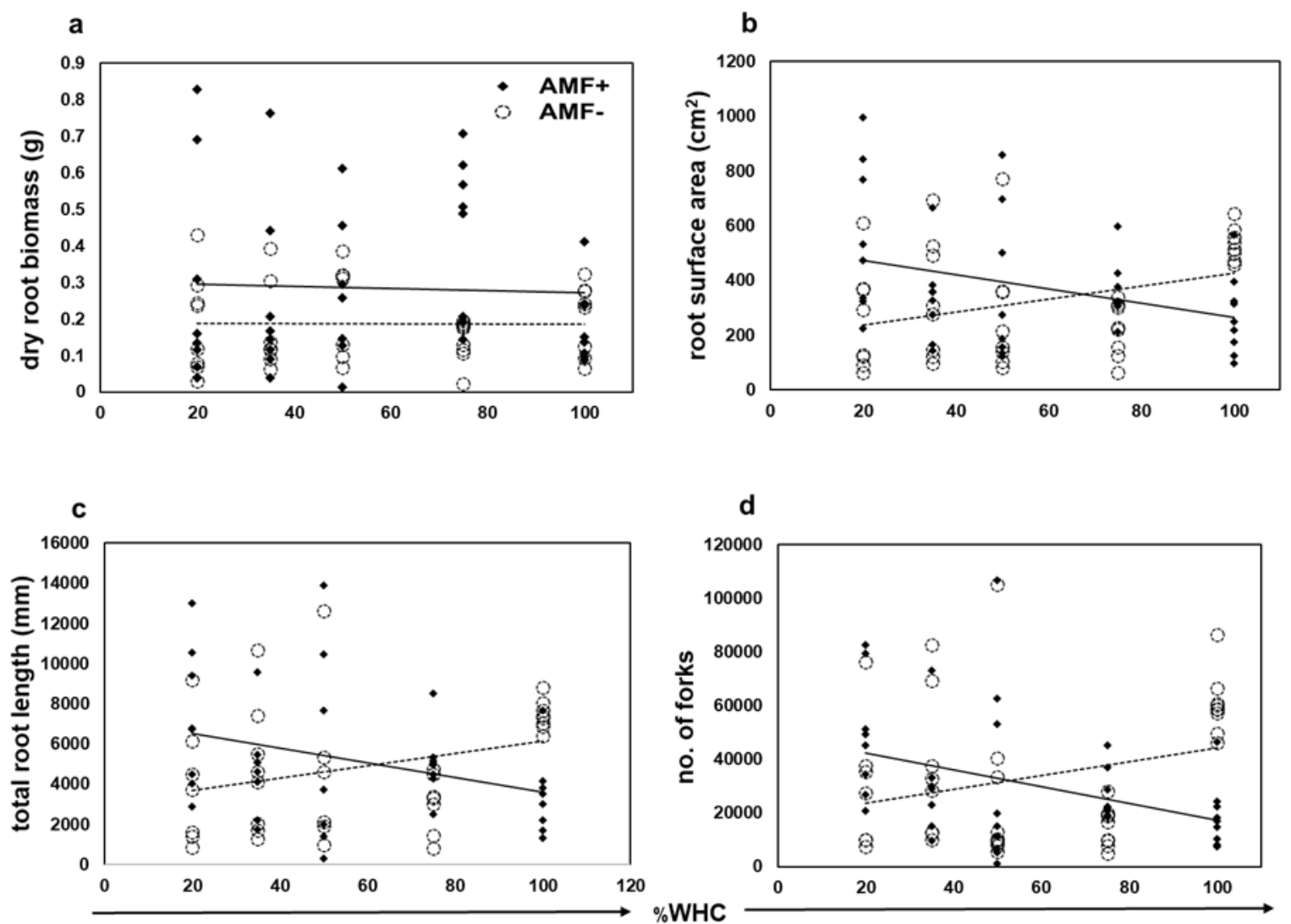
Figure 10

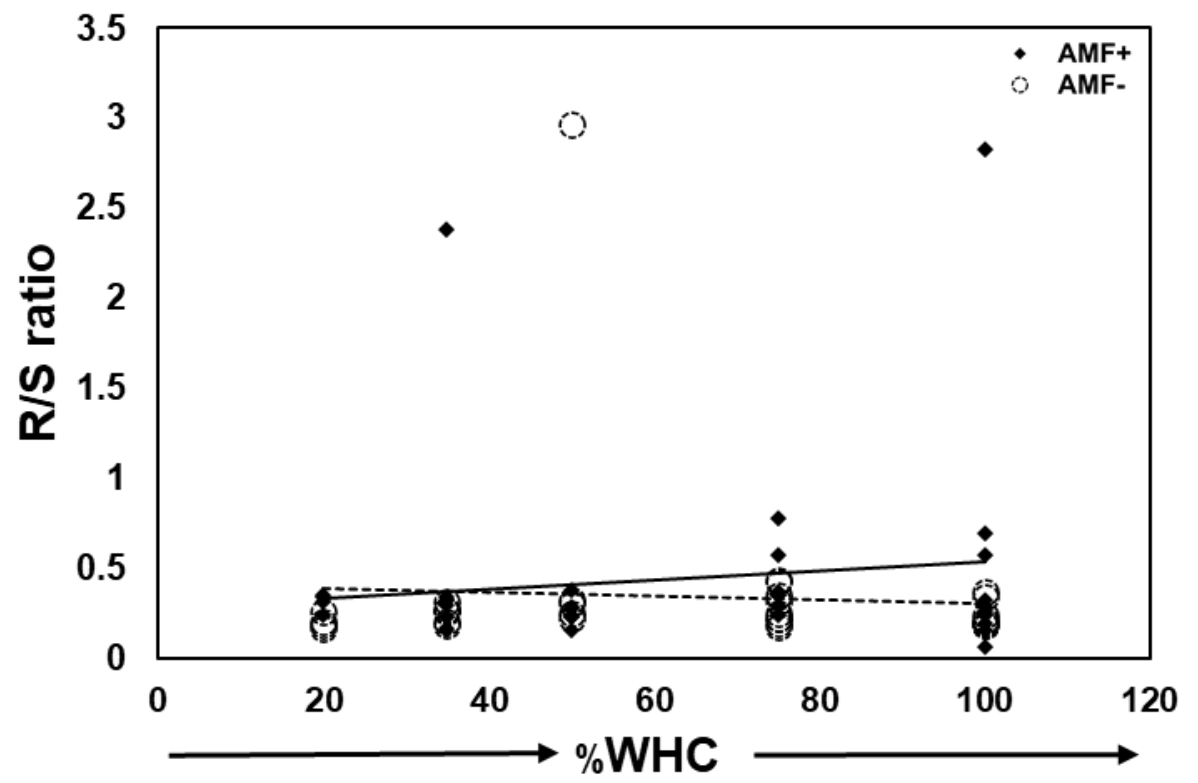


Figure 11
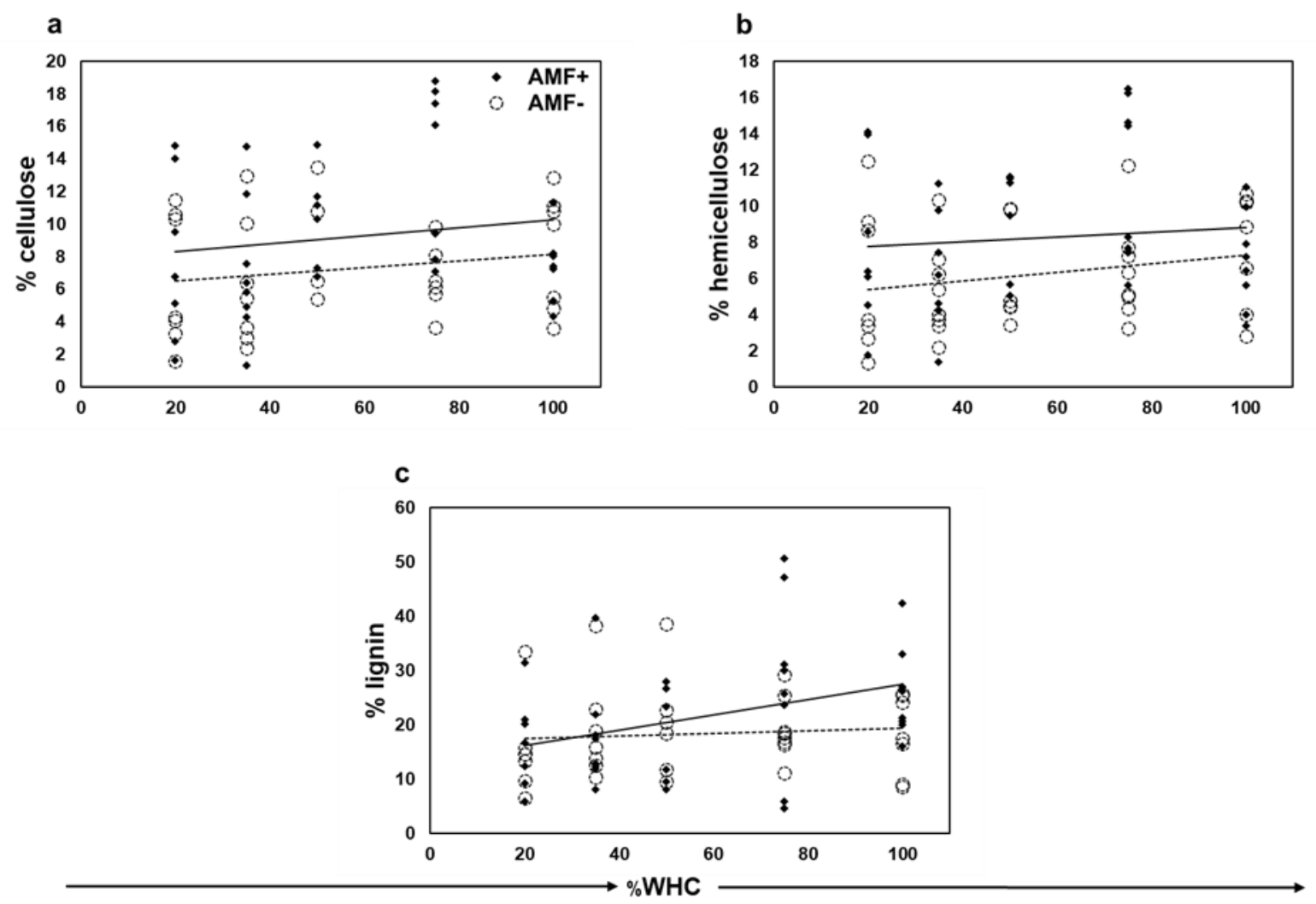


\section{CHAPTER V}

\section{SUMMARY AND FUTURE DIRECTIONS}

\section{SUMMARY}

This dissertation research demonstrates that AM fungi affect above- and belowground growth and physiological responses in switchgrass over a wide range of biotic and abiotic stresses, and generally finds that AM fungi are beneficial. The first growth chamber study demonstrated the ability of AM fungi to provide bio-protection to switchgrass against PPNs. There are multiple mechanisms for AM fungi mediated biocontrol of nematodes such as enhanced nutrition, change in root morphology, or activation of systemic or induced resistance. We suspected increased root lignification due to the fungal colonization which could potentially bar the nematodes from penetrating the roots. We followed this experiment with a biocide field study to investigate the effects of switchgrass interactions with belowground organisms like AM fungi and PPN on plant lignin content and monomeric composition. Although we did not observe any changes in total lignin content due to belowground interactions, we found alterations in the composition of lignin towards lower S/G ratios. Since lignin with lower $\mathrm{S} / \mathrm{G}$ or $\mathrm{S}$ monomer abundance tends to have higher enzymatic recalcitrance and increases plant toughness, the biocontrol of PPNs in our first study could potentially be due to such 
alteration in lignin composition. Unfortunately, we could not analyze cell wall chemistry in our first experiment due to the lack of sufficient biomass. Chapter four of this dissertation examined how AM fungi influence plant growth and physiology along a drought gradient. AM fungi were found to enhance plant growth under low soil moisture, with diminishing benefits along the gradient towards high soil moisture. Findings from these studies generally corroborate results from previous studies that AM fungi have positive effects on plant growth under a variety of biotic and abiotic stresses, and sheds new light on how cell wall chemistry responds to AM fungi under drought conditions.

\section{FUTURE DIRECTIONS}

My future research interests lie in asking ecological questions concerning aboveground-belowground interactions in an applied agricultural context. I aim to investigate the role of belowground factors on plants' abilities to cope with climate change-induced biotic and abiotic stresses.

To further my dissertation work, I am interested in performing gene expression analysis to understand mycorrhizal effects on the biosynthesis of cell wall components with potential application in biofuel production. I am further interested in exploring the potential of incorporating mycorrhizal symbiosis into agriculture by expanding my experiments with switchgrass to cereal and horticultural crops. There are plenty of opportunities for mycorrhizal research in that direction (Rooney et al. 2009; Sawers et al. 2008). Given that mycorrhizal fungi generally are beneficial to their host plants, land management practices, especially in agriculture should focus on improving fungal abundance and richness. Applied research should focus on the combination of both plant and fungal traits to optimize the benefits of mycorrhizal symbiosis. For example, 
identifying plants or developing cultivars with an enhanced ability to benefit from AM symbiosis as well as identifying or engineering AM species that provide maximum benefits to their host is an exciting opportunity for mycorrhizal research.

In the third chapter of this dissertation, I made use of a long-term experiment at KBS LTER. Nitrogen fertilization was a long-term treatment whereas the biocide treatment was done over a single season. Despite a single season manipulation of AM fungi and soil nematodes, they exhibited similar magnitude of effects on some lignin measures, which is remarkable. This begs a question: how does long term manipulation of soil (tillage, fertilization, biocide application, monocropping) affect the functioning of the AM fungal symbiosis? There are plenty of avenues such as LTER or Long Term Agroecosystem Research (LTAR) studies to address such questions.

The growth chamber studies in this dissertation looked at one species of AM fungi and one species of PPN. However, in a natural setting, multiple AM fungal species interact with each other and other root endosymbionts (Mack and Rudgers 2008; Scheublin et al. 2004). While a reductionist approach of understanding specific mechanism of how one AM species affects a particular gene expression which ultimately affects plant phenotype is important, it is equally important to unravel how plant-AM fungal interactions play out in population and community context amidst a suite of multiple biotic and abiotic actors. It would be interesting to evaluate how AM fungal diversity respond to a wide range of environmental gradients and how that affects plant performance. The rapid advancement and low cost of 'omics' tool and molecular characterization techniques allow us more than ever to investigate the plant-AM 
functioning from organismal to community scale across a wide variety of environmental gradients. 


\section{REFERENCES}

Abdi H, Williams LJ 2010 Tukey's honestly significant difference (HSD) test Encyclopedia of Research Design Thousand Oaks, CA: Sage:1-5

Achten WM, Maes WH, Reubens B, Mathijs E, Singh VP, Verchot L, Muys B 2010 Biomass production and allocation in Jatropha curcas L. seedlings under different levels of drought stress biomass and bioenergy 34:667-676

Alam SM 1999 Nutrient uptake by plants under stress conditions Handbook of plant and crop stress 2:285-313

Alban R., Guerrero R. and Toro M. 2013. Interactions between a root knot nematode (Meloidogyne exigua) and arbuscular mycorrhizae in coffee plant development (Coffea arabica). American J of Plant Sci 4: 19.

Alderson J., Sharp W. 1994 Grass varieties in the United States. Agricultural Handbook No. 170. Soil Conserv. Serv., USDA, Washington, DC

Al-Karaki G, Al-Raddad A 1997 Effects of arbuscular mycorrhizal fungi and drought stress on growth and nutrient uptake of two wheat genotypes differing in drought resistance Mycorrhiza 7:83-88

Al-Karaki G., McMichael B. and Zak J. 2004. Field response of wheat to arbuscular mycorrhizal fungi and drought stress. Mycorrhiza 14: 263-269.

Al-Karaki GN 1998 Benefit, cost and water-use efficiency of arbuscular mycorrhizal durum wheat grown under drought stress Mycorrhiza 8:41-45

Allen MF 1991 The ecology of mycorrhizae. Cambridge University Press,

Allen MF 1996 The ecology of arbuscular mycorrhizas: a look back into the 20th century and a peek into the 21st Mycol Res 100:769-782

Anderson R, Liberta A, Dickman L 1984 Interaction of vascular plants and vesiculararbuscular mycorrhizal fungi across a soil moisture-nutrient gradient Oecologia 64:111-117

Anjos É.C.T.d., Cavalcante U.M.T., Gonçalves D.M.C., Pedrosa E.M.R., Santos V.F.d. and Maia L.C. 2010. Interactions between an arbuscular mycorrhizal fungus (Scutellospora heterogama) and the root-knot nematode (Meloidogyne incognita) on sweet passion fruit (Passiflora alata). Brazilian Archives of Biology and Technology 53: 801-809. 
ANKOM $^{200} 2016$ Technical Support Fiber Analyzer A200.

https://www.ankom.com/technical-support/fiber-analyzer-a200. Accessed $01 / 24 / 2020$

Asada Y, Matsumoto I 1972 The Nature of Lignin obtained from Downy Mildewinfected Japanese Radish Root 1 J Phytopathol 73:208-214Asrar A, Abdel-Fattah G, Elhindi K 2012 Improving growth, flower yield, and water relations of snapdragon (Antirhinum majus L.) plants grown under well-watered and waterstress conditions using arbuscular mycorrhizal fungi Photosynthetica 50:305-316

Augé R.M. 2004. Arbuscular mycorrhizae and soil/plant water relations. Can J Soil Sci 84: $373-381$.

Augé R.M., Schekel K.A. and Wample R.L. 1986. Osmotic adjustment in leaves of VA mycorrhizal and nonmycorrhizal rose plants in response to drought stress. Plant Physiol 82: 765-770.

Augé RM 2001 Water relations, drought and vesicular-arbuscular mycorrhizal symbiosis Mycorrhiza 11:3-42

Augé RM, Schekel KA, Wample RL 1986 Osmotic adjustment in leaves of VA mycorrhizal and nonmycorrhizal rose plants in response to drought stress Plant Physiology 82:765-770

Barrière Y et al. 2004 Genetic and molecular basis of grass cell wall biosynthesis and degradability. II. Lessons from brown-midrib mutants Comptes rendus biologies 327:847-860

Baslam M, Antolín MC, Gogorcena Y, Muñoz F, Goicoechea N 2014 Changes in alfalfa forage quality and stem carbohydrates induced by arbuscular mycorrhizal fungi and elevated atmospheric CO2 Ann Appl Biol 164:190-199

Baslam M, Garmendia I, Goicoechea N 2011 Arbuscular mycorrhizal fungi (AMF) improved growth and nutritional quality of greenhouse-grown lettuce Journal of agricultural and food chemistry 59:5504-5515

Bayne H.G., Brown M.S. and Bethlenfalvay G.J. 1984. Defoliation effects on mycorrhizal colonization, nitrogen fixation and photosynthesis in the GlycineGlomus-Rhizobium symbiosis. Physiol Plantarum 62: 576-580.

Bennett A.E. and Bever J.D. 2007. Mycorrhizal species differentially alter plant growth and response to herbivory. Ecology 88: 210-218.

Bennett AE, Grussu D, Kam J, Caul S, Halpin C 2015 Plant lignin content altered by soil microbial community New Phytologist 206:166-174

Bernard G.C., Egnin M. and Bonsi C. 2017. The Impact of Plant-Parasitic Nematodes on Agriculture and Methods of Control. Nematology-Concepts, Diagnosis and Control: 121. 
Bethlenfalvay G.J., Brown M.S., Ames R.N. and Thomas R.S. 1988. Effects of drought on host and endophyte development in mycorrhizal soybeans in relation to water use and phosphate uptake. Physiol Plantarum 72: 565-571.

Blodgett JT, Herms DA, Bonello P 2005 Effects of fertilization on red pine defense chemistry and resistance to Sphaeropsis sapinea For Ecol Manage 208:373-382

Bloem J., de Ruiter P.C., Koopman G.J., Lebbink G. and Brussaard L. 1992. Microbial numbers and activity in dried and rewetted arable soil under integrated and conventional management. Soil Biol Biochem 24: 655-665.

Blum A. and Jordan W.R. 1985. Breeding crop varieties for stress environments. Cr Rev Plant Sci 2:199-238

Bonello P, Blodgett JT 2003 Pinus nigra-Sphaeropsis sapinea as a model pathosystem to investigate local and systemic effects of fungal infection of pines Physiological and Molecular Plant Pathology 63:249-261

Boomsma CR, Vyn TJ 2008 Maize drought tolerance: potential improvements through arbuscular mycorrhizal symbiosis? Field Crops Res 108:14-31

Bouton JH 2007 Molecular breeding of switchgrass for use as a biofuel crop Curr Opin Genet Dev 17:553-558

Brejda JJ, Yocom D, Moser LE, Waller SS 1993 Dependence of 3 Nebraska Sandhills warm-season grasses on vesicular-arbuscular mycorrhizae Journal of Range Management:14-20

Byrt CS, Grof CP, Furbank RT 2011 C4 Plants as biofuel feedstocks: optimising biomass production and feedstock quality from a lignocellulosic perspective free access Journal of Integrative Plant Biology 53:120-135

Calvet C., Pinochet J., Hernández-Dorrego A., Estaún V. and Camprubí A. 2001. Field microplot performance of the peach-almond hybrid GF-677 after inoculation with arbuscular mycorrhizal fungi in a replant soil infested with root-knot nematodes. Mycorrhiza 10: 295-300.

Campbell Scientific 2020 HydroSense II Handheld Soil Moisture Sensor. https://www.campbellsci.com/hs2. Accessed 01/24/2020

Carnicer J., Coll M., Ninyerola M., Pons X., Sanchez G. and Penuelas J. 2011. Widespread crown condition decline, food web disruption, and amplified tree mortality with increased climate change-type drought. P Natl A Sci 108: 14741478.

Casler M., Vogel K.P., Taliaferro C. and Wynia R. 2004. Latitudinal adaptation of switchgrass populations. Crop Sci 44: 293-303.

Cassida K., Kirkpatrick T., Robbins R., Muir J., Venuto B. and Hussey M. 2005. Plantparasitic nematodes associated with switchgrass (Panicum virgatum L.) grown for biofuel in the South Central United States. Nematropica 35: 1-10. 
Castellanos-Morales V, Villegas J, Wendelin S, Vierheilig H, Eder R, Cárdenas-Navarro R 2010 Root colonisation by the arbuscular mycorrhizal fungus Glomus intraradices alters the quality of strawberry fruits (Fragariax ananassa Duch.) at different nitrogen levels J Sci Food Agric 90:1774-1782

Chapotin S.M. and Wolt J.D. 2007. Genetically modified crops for the bioeconomy: meeting public and regulatory expectations. Transgenic Res 16: 675-688.

Chaves M.M., Flexas J. and Pinheiro C. 2009. Photosynthesis under drought and salt stress: regulation mechanisms from whole plant to cell. Ann Bot-London 103: $551-560$

Chen F, Dixon RA 2007 Lignin modification improves fermentable sugar yields for biofuel production Nature biotechnology 25:759

Chen XW, Kang Y, San So P, Ng CWW, Wong MH 2018 Arbuscular mycorrhizal fungi increase the proportion of cellulose and hemicellulose in the root stele of vetiver grass Plant and Soil 425:309-319

Claflin L (1983) Plant-parasitic nematodes affecting sorghum Sorghum Root and Stalk Rots:53

Clark R., Baligar V. and Zobel R. 2005. Response of mycorrhizal switchgrass to phosphorus fractions in acidic soil. Commun Soil Sci Plan 36: 1337-1359.

Clark R., Zeto S. and Zobel R. 1999. Arbuscular mycorrhizal fungal isolate effectiveness on growth and root colonization of Panicum virgatum in acidic soil. Soil Biol Biochem 31: 1757-1763.

Coleman-Derr D. and Tringe S.G. 2014. Building the crops of tomorrow: advantages of symbiont-based approaches to improving abiotic stress tolerance. Front Microbiol 5: 283.

Congress U 2007 Energy independence and security act of 2007 Public law 2:110-140

Cortese L.M. and Bonos S.A. 2013. Bioenergy traits of ten switchgrass populations grown in the Northeastern/Mid-Atlantic USA. Bioenerg Res 6: 580-590.

Cox C.S. and McEvoy P.B. 1983. Effect of summer moisture stress on the capacity of tansy ragwort (Senecio jacobaea) to compensate for defoliation by cinnabar moth (Tyria jacobaeae). J Appl Ecol: 225-234.

Crawley M.J. 1989. Insect herbivores and plant population dynamics. Annu Rev Entomol 34: 531-562.

Daft M. and El-Giahmi A. 1978. Effect of arbuscular mycorrhiza on plant growth: viii. effects of defoliation and light on selected hosts. New Phytol 80: 365-372.

Davies Jr F, Potter J, Linuerman R 1993 Drought resistance of mycorrhizal pepper plants independent of leaf $\mathrm{P}$ concentration-response in gas exchange and water relations Physiologia Plantarum 87:45-53 
Davies Jr F., Potter J. and Linderman R. 1992. Mycorrhiza and repeated drought exposure affect drought resistance and extraradical hyphae development of pepper plants independent of plant size and nutrient content. Journal of Plant Physiol 139: 289-294.

de Graaff M.-A., Six J., Jastrow J.D., Schadt C.W. and Wullschleger S.D. 2013. Variation in root architecture among switchgrass cultivars impacts root decomposition rates. Soil Biol Biochem 58: 198-206.

De La Peña E., Echeverría S.R., Van Der Putten W.H., Freitas H. and Moens M. 2006. Mechanism of control of root-feeding nematodes by mycorrhizal fungi in the dune grass Ammophila arenaria. New Phytol 169: 829-840.

Detering S, Dettmann S, Thierfelder H, Mahna SK, Prasad B, Shamseldin AY, Werner D 2005 Glycosidase and glycosyltransferase activity increase in arbuscular mycorrhiza infected legume roots Symbiosis 40:157-162

Drüge U, Schonbeck F 1993 Effect of vesicular-arbuscular mycorrhizal infection on transpiration, photosynthesis and growth of flax (Linum usitatissimum L.) in relation to cytokinin levels Journal of Plant Physiology 141:40-48

Druzhinina I.S., Seidl-Seiboth V., Herrera-Estrella A., Horwitz B.A., Kenerley C.M., Monte E., Mukherjee P.K., Zeilinger S., Grigoriev I.V. and Kubicek C.P. 2011. Trichoderma: the genomics of opportunistic success. Nat Rev Microbiol 9: 749.

Duan X., Neuman D.S., Reiber J.M., Green C.D., Saxton A.M. and Augé R.M. 1996. Mycorrhizal influence on hydraulic and hormonal factors implicated in the control of stomatal conductance during drought. J Exp Bot 47: 1541-1550.

Earl HJ 2003 A precise gravimetric method for simulating drought stress in pot experiments Crop Science 43:1868-1873

Eissenstat D, Wells C, Yanai R, Whitbeck J (2000) Building roots in a changing environment: implications for root longevity The New Phytologist 147:33-42

Ellis J, Larsen H, Boosalis M 1985 Drought resistance of wheat plants inoculated with vesicular-arbuscular mycorrhizae Plant and Soil 86:369-378

Elsen A., Beeterens R., Swennen R. and De Waele D. 2003. Effects of an arbuscular mycorrhizal fungus and two plant-parasitic nematodes on Musa genotypes differing in root morphology. Biol Fert Soils 38: 367-376.

Elsen A., Gervacio D., Swennen R. and De Waele D. 2008. AMF-induced biocontrol against plant parasitic nematodes in Musa sp.: a systemic effect. Mycorrhiza 18: 251-256.

Emery S.M., Kinnetz E.R., Bell-Dereske L., Stahlheber K.A., Gross K.L. and Pennington D. 2018. Low variation in arbuscular mycorrhizal fungal associations and effects on biomass among switchgrass cultivars. Biomass Bioenerg 119: 503-508. 
Emery S.M., Reid M.L., Bell-Dereske L. and Gross K.L. 2017. Soil mycorrhizal and nematode diversity vary in response to bioenergy crop identity and fertilization. Gcb Bioenergy 9: 1644-1656.

Emery SM, Stahlheber KA, Gross KL 2020 Drought minimized nitrogen fertilization effects on bioenergy feedstock quality Biomass and Bioenergy 133:105452

Engbers HM 2012 Evaluation of nitrogen fertilization in C4 grasses grown for bioenergy.

Entry JA, Runion GB, Prior SA, Mitchell RJ, Rogers HH 1998 Influence of CO 2 enrichment and nitrogen fertilization on tissue chemistry and carbon allocation in longleaf pine seedlings. In: Root demographics and their efficiencies in sustainable agriculture, grasslands and forest ecosystems. Springer, pp 3-18

Eziz A, Yan Z, Tian D, Han W, Tang Z, Fang J 2017 Drought effect on plant biomass allocation: A meta-analysis Ecology and evolution 7:11002-11010

Fan L, Linker R, Gepstein S, Tanimoto E, Yamamoto R, Neumann PM 2006 Progressive inhibition by water deficit of cell wall extensibility and growth along the elongation zone of maize roots is related to increased lignin metabolism and progressive stelar accumulation of wall phenolics Plant physiology 140:603-612

Fiorilli V, Catoni M, Miozzi L, Novero M, Accotto GP, Lanfranco L 2009 Global and cell-type gene expression profiles in tomato plants colonized by an arbuscular mycorrhizal fungus New Phytologist 184:975-987

Fitter A 1988 Water relations of red clover Trifolium pratense L. as affected by VA mycorrhizal infection and phosphorus supply before and during drought Journal of Experimental Botany 39:595-603

Fontana A, Reichelt M, Hempel S, Gershenzon J, Unsicker SB 2009 The effects of arbuscular mycorrhizal fungi on direct and indirect defense metabolites of Plantago lanceolata L Journal of chemical ecology 35:833-843

Foster CE, Martin TM, Pauly M 2010 Comprehensive compositional analysis of plant cell walls (lignocellulosic biomass) part I: lignin JoVE (Journal of Visualized Experiments):e1745

Frank A, Berdahl J, Hanson J, Liebig M, Johnson H 2004 Biomass and carbon partitioning in switchgrass Crop Science 44:1391-1396

Franson R.L., Brown M.S. and Bethlenfalvay G.J. 1991. The Glycine-GlomusBradyrhizobiun symbiosis. XI. Nodule gas exchange and efficiency as a function of soil and root water status in mycorrhizal soybean. Physiol Plantarum 83: 476482.

Ganz T, Kailis S, Abbott L 2002 Mycorrhizal colonization and its effect on growth, phosphorus uptake and tissue phenolic content in the European olive (Olea europaea L.) Advances in horticultural science:109-116 
Gill R. 1992. A review of damage by mammals in north temperate forests: 3. Impact on trees and forests. Forestry: An International Journal of Forest Research 65: 363388.

Gindl W, Grabner M, Wimmer R (2000) The influence of temperature on latewood lignin content in treeline Norway spruce compared with maximum density and ring width Trees 14:409-414 doi:10.1007/s004680000057

Giovannetti M, Mosse B (1980) An evaluation of techniques for measuring vesicular arbuscular mycorrhizal infection in roots New phytologist 84:489-500

Goicoechea-Preboste N, Garmendia I, Sanchez-Diaz M, Aguirreolea J (2010) Arbuscular mycorrhizal fungi (AMF) as bioprotector agents against wilt induced by Verticillium spp. in pepper

Gutbrodt B., Mody K. and Dorn S. 2011. Drought changes plant chemistry and causes contrasting responses in lepidopteran herbivores. Oikos 120: 1732-1740.

Hao Z., Fayolle L., van Tuinen D., Chatagnier O., Li X., Gianinazzi S. and GianinazziPearson V. 2012. Local and systemic mycorrhiza-induced protection against the ectoparasitic nematode Xiphinema index involves priming of defence gene responses in grapevine. J Exp Bot 63: 3657-3672.

Harrier LA, Watson CA 2004 The potential role of arbuscular mycorrhizal (AM) fungi in the bioprotection of plants against soil-borne pathogens in organic and/or other sustainable farming systems Pest Management Science: formerly Pesticide Science 60:149-157

Hartman JC, Nippert JB, Orozco RA, Springer CJ 2011 Potential ecological impacts of switchgrass (Panicum virgatum L.) biofuel cultivation in the Central Great Plains, USA biomass and bioenergy 35:3415-3421

Hausman JF, Evers D, Thiellement H, Jouve L 2000 Compared responses of poplar cuttings and in vitro raised shoots to short-term chilling treatments Plant Cell Reports 19:954-960 doi:10.1007/s002990000229

He C, Wolyn D 2005 Potential role for salicylic acid in induced resistance of asparagus roots to Fusarium oxysporum f. sp. asparagi Plant Pathology 54:227-232

Hetrick BD, Leslie J, Wilson GT, Kitt DG 1988 Physical and topological assessment of effects of a vesicular-arbuscular mycorrhizal fungus on root architecture of big bluestem New Phytologist 110:85-96

Hodge A, Berta G, Doussan C, Merchan F, Crespi M 2009 Plant root growth, architecture and function Plant and soil 321:153-187

Huang WK, Ji HL, Gheysen G, Kyndt T 2016 Thiamine-induced priming against rootknot nematode infection in rice involves lignification and hydrogen peroxide generation Molecular plant pathology 17:614-624

Huntley SK, Ellis D, Gilbert M, Chapple C, Mansfield SD 2003 Significant increases in pulping efficiency in $\mathrm{C} 4 \mathrm{H}-\mathrm{F} 5 \mathrm{H}$-transformed poplars: improved chemical savings 
and reduced environmental toxins Journal of Agricultural and Food Chemistry 51:6178-6183

Jakobsen I, Rosendahl L 1990 Carbon flow into soil and external hyphae from roots of mycorrhizal cucumber plants New Phytologist 115:77-83

Janos D.P., Scott J., Aristizábal C. and Bowman D.M. 2013. Arbuscular-mycorrhizal networks inhibit Eucalyptus tetrodonta seedlings in rain forest soil microcosms. PLoS One 8: e57716.

Jayne B, Quigley M 2014 Influence of arbuscular mycorrhiza on growth and reproductive response of plants under water deficit: a meta-analysis Mycorrhiza 24:109-119

Jenkins W 1964 A rapid centrifugal-flotation technique for separating nematodes from soil Plant disease reporter 48

Johnson N.C., Graham J. and Smith F. 1997. Functioning of mycorrhizal associations along the mutualism-parasitism continuum. The New Phytol 135: 575-585.

Jung HJG, Vogel KP 1992 Lignification of switchgrass (Panicum virgatum) and big bluestem (Andropogon gerardii) plant parts during maturation and its effect on fibre degradability J Sci Food Agric 59:169-176

Jung S.C., Martinez-Medina A., Lopez-Raez J.A. and Pozo M.J. 2012. Mycorrhizainduced resistance and priming of plant defenses. J Chem Ecol 38: 651-664.

Kaya M.D., Okçu G., Atak M., Cıkılı Y. and Kolsarıcı Ö. 2006. Seed treatments to overcome salt and drought stress during germination in sunflower (Helianthus annuus L.). Eur J Agron 24: 291-295.

Koffi M.C., Vos C., Draye X. and Declerck S. 2013. Effects of Rhizophagus irregularis MUCL 41833 on the reproduction of Radopholus similis in banana plantlets grown under in vitro culture conditions. Mycorrhiza 23: 279-288.

Koide R.T. 1993. Physiology of the mycorrhizal plant. Adv Plant Pathol 9: 33-54.

Koricheva J., Gange A.C. and Jones T. 2009. Effects of mycorrhizal fungi on insect herbivores: a meta-analysis. Ecology 90: 2088-2097.

Korte C, Chu A Some effects of drought on perennial ryegrass swards. In: Proceedings of the New Zealand Grassland Association, 1983. pp 211-216

Kostiainen K, Kaakinen S, Saranpää P, Sigurdsson BD, Linder S, Vapaavuori E 2004 Effect of elevated [CO2] on stem wood properties of mature Norway spruce grown at different soil nutrient availability Global Change Biology 10:1526-1538

Kothari S., Marschner H. and George E. 1990. Effect of VA mycorrhizal fungi and rhizosphere microorganisms on root and shoot morphology, growth and water relations in maize. New Phytol 116: 303-311.

Lange BM, Lapierre C, Sandermann Jr H 1995 Elicitor-induced spruce stress lignin (structural similarity to early developmental lignins) Plant Physiology 108:12771287 
Lee BR, Muneer S, Jung WJ, Avice JC, Ourry A, Kim TH 2012 Mycorrhizal colonization alleviates drought-induced oxidative damage and lignification in the leaves of drought-stressed perennial ryegrass (Lolium perenne) Physiologia plantarum 145:440-449

Lemus R, Brummer EC, Burras CL, Moore KJ, Barker MF, Molstad NE 2008 Effects of nitrogen fertilization on biomass yield and quality in large fields of established switchgrass in southern Iowa, USA Biomass and Bioenergy 32:1187-1194

Lemus R., Brummer E.C., Moore K.J., Molstad N.E., Burras C.L. and Barker M.F. 2002. Biomass yield and quality of 20 switchgrass populations in southern Iowa, USA. Biomass Bioenerg 23: 433-442.

Leung T. and Poulin R. 2008. Parasitism, commensalism, and mutualism: exploring the many shades of symbioses. Vie Milieu 58: 107.

Lewandowski I., Scurlock J.M., Lindvall E. and Christou M. 2003. The development and current status of perennial rhizomatous grasses as energy crops in the US and Europe. Biomass Bioenerg 25: 335-361.

Li X, Ximenes E, Kim Y, Slininger M, Meilan R, Ladisch M, Chapple C 2010 Lignin monomer composition affects Arabidopsis cell-wall degradability after liquid hot water pretreatment Biotechnology for biofuels 3:27

Lipiec J, Doussan C, Nosalewicz A, Kondracka K 2013 Effect of drought and heat stresses on plant growth and yield: a review International Agrophysics 27:463477

Liu J, Wu N, Wang H, Sun J, Peng B, Jiang P, Bai E 2016 Nitrogen addition affects chemical compositions of plant tissues, litter and soil organic matter Ecology 97:1796-1806

Mack KM, Rudgers JA 2008 Balancing multiple mutualists: asymmetric interactions among plants, arbuscular mycorrhizal fungi, and fungal endophytes Oikos $117: 310-320$

Manickavelu A., Nadarajan N., Ganesh S., Gnanamalar R. and Babu R.C. 2006. Drought tolerance in rice: morphological and molecular genetic consideration. Plant Growth Regul 50: 121-138.

Marulanda A., Barea J.-M. and Azcón R. 2009. Stimulation of plant growth and drought tolerance by native microorganisms (AM fungi and bacteria) from dry environments: mechanisms related to bacterial effectiveness. J Plant Growth Regul 28: 115-124.

Maschinski J. and Whitham T.G. 1989. The continuum of plant responses to herbivory: the influence of plant association, nutrient availability, and timing. The Am Nat 134: 1-19.

McGonigle T, Miller M, Evans D, Fairchild G, Swan J 1990 A new method which gives an objective measure of colonization of roots by vesicular - arbuscular mycorrhizal fungi New phytologist 115:495-501 
McLaughlin S.B. and Kszos L.A. 2005. Development of switchgrass (Panicum virgatum) as a bioenergy feedstock in the United States. Biomass Bioenerg 28: 515-535.

Meehl G.A. and Tebaldi C. 2004. More intense, more frequent, and longer lasting heat waves in the 21st century. Science 305: 994-997.

Mekete T., Reynolds K., Lopez-Nicora H.D., Gray M.E. and Niblack T.L. 2011. Plantparasitic nematodes are potential pathogens of Miscanthus $\times$ giganteus and Panicum virgatum used for biofuels. Plant Dis 95: 413-418.

Menden B, Kohlhoff M, Moerschbacher BM 2007 Wheat cells accumulate a syringylrich lignin during the hypersensitive resistance response Phytochemistry 68:513520

Michigan State University 2020 M Kellogg Biological Station LTER "Cellulosic Biofuels Diversity Experiment" https://ter.kbs.msu.edu/research/long-termexperiments/cellulosic-biofuels-experiment/. Accessed 9 March 2020

Milchunas DG 2012 Biases and errors associated with different root production methods and their effects on field estimates of belowground net primary production. In: Measuring Roots. Springer, pp 303-339

Miller JN, VanLoocke A, Gomez-Casanovas N, Bernacchi CJ 2016 Candidate perennial bioenergy grasses have a higher albedo than annual row crops Gcb Bioenergy $8: 818-825$

Mitchell RB, Lee D, Casler M 2014 Switchgrass

Moles A.T. and Westoby M. 2004. Seed mass and seedling establishment after fire in Kuring-gai Chase National Park, Sydney, Australia. Austral Ecology 29: 383-390.

Moore JP, Vicré-Gibouin M, Farrant JM, Driouich A 2008 Adaptations of higher plant cell walls to water loss: drought vs desiccation Physiologia plantarum 134:237245

Morandi D 1996 Occurrence of phytoalexins and phenolic compounds in endomycorrhizal interactions, and their potential role in biological control Plant and soil 185:241-251

Morrow III WR, Gopal A, Fitts G, Lewis S, Dale L, Masanet E 2014 Feedstock loss from drought is a major economic risk for biofuel producers Biomass and Bioenergy 69:135-143

Moura JCMS, Bonine CAV, de Oliveira Fernandes Viana J, Dornelas MC, Mazzafera P 2010 Abiotic and biotic stresses and changes in the lignin content and composition in plants Journal of integrative plant biology 52:360-376

Muñoz JD, Kravchenko A 2011 Soil carbon mapping using on-the-go near infrared spectroscopy, topography and aerial photographs Geoderma 166:102-110

Neuhauser C, Fargione JE 2004 A mutualism-parasitism continuum model and its application to plant-mycorrhizae interactions Ecol Model 177:337-352 
Nicol J.M., Turner S.J., Coyne D., Den Nijs L., Hockland S. and Maafi Z.T. 2011. Current nematode threats to world agriculture. Genomics and molecular genetics of plant-nematode interactions. Springer, pp. 21-43.

Oka Y The new nematicide nimitz (fluensulfone): its advantages and limitations. in: journal of nematology, 2014. vol 2. soc nematologists po box 311, marceline, mo 64658 USA, pp 214-214

Oláh B, Brière C, Bécard G, Dénarié J, Gough C 2005 Nod factors and a diffusible factor from arbuscular mycorrhizal fungi stimulate lateral root formation in Medicago truncatula via the DMI1/DMI2 signalling pathway The Plant Journal 44:195-207

Olsson PA, Rahm J, Aliasgharzad N 2010 Carbon dynamics in mycorrhizal symbioses is linked to carbon costs and phosphorus benefits FEMS microbiology ecology $72: 125-131$

Paracer S, Ahmadjian V 2000 Symbiosis: an introduction to biological associations. Oxford University Press on Demand,

Parrott DL, Anderson AJ, Carman JG 2002 Agrobacterium induces plant cell death in wheat (Triticum aestivum L.) Physiological and molecular plant pathology 60:5969

Pautasso M, Döring TF, Garbelotto M, Pellis L, Jeger MJ 2012 Impacts of climate change on plant diseases_ — opinions and trends Eur J Plant Pathol 133:295-313

Perry TO 1982 The ecology of tree roots and the practical significance thereof Journal of Arboriculture 8:197-211

Pinkerton A. and Simpson J. 1986. Interactions of surface drying and subsurface nutrients affecting plant growth on acidic soil profiles from an old pasture. Aust J Exp Agr26: 681-689.

Pischl PH, Barber NA (2017) Plant responses to arbuscular mycorrhizae under elevated temperature and drought Journal of Plant Ecology 10:692-701

Pitre FE, Cooke JEK, Mackay JJ 2007 Short-term effects of nitrogen availability on wood formation and fibre properties in hybrid poplar Trees 21:249-259 doi:10.1007/s00468-007-0123-5

Pozo M.J. and Azcón-Aguilar C. 2007. Unraveling mycorrhiza-induced resistance. Curr Opin Plant Biol 10: 393-398.

Pozo M.J., Cordier C., Dumas-Gaudot E., Gianinazzi S., Barea J.M. and Azcón-Aguilar C. 2002. Localized versus systemic effect of arbuscular mycorrhizal fungi on defence responses to Phytophthora infection in tomato plants. J Exp Bot 53: 525534.

Price N., Roncadori R. and Hussey R. 1989. Cotton root growth as influenced by phosphorus nutrition and vesicular-arbuscular mycorrhizas. New Phytol 111: 6166. 
Reynolds S. 1970. The gravimetric method of soil moisture determination Part IA study of equipment, and methodological problems. J Hydrol 11: 258-273.

Rich MK, Schorderet M, Reinhardt D 2014 The role of the cell wall compartment in mutualistic symbioses of plants Frontiers in Plant Science 5:238

Rinehart L 2006 Switchgrass as a bioenergy crop National Center for Appropriate Technology, Available online at: http://attra ncat org/attra-pub/PDF/switchgrass pdf

Rodríguez-Morelos V.H., Soto-Estrada A., Pérez-Moreno J., Franco-Ramírez A. and Díaz-Rivera P. 2014. Arbuscular mycorrhizal fungi associated with the rhizosphere of seedlings and mature trees of Swietenia macrophylla (Magnoliophyta: Meliaceae) in Los Tuxtlas, Veracruz, Mexico. Rev Chil Hist Nat 87: 9 .

Rooney DC, Killham K, Bending GD, Baggs E, Weih M, Hodge A 2009 Mycorrhizas and biomass crops: opportunities for future sustainable development Trends in plant science 14:542-549

Rosumek F.B., Silveira F.A., Neves F.d.S., Barbosa N.P.d.U., Diniz L., Oki Y., Pezzini F., Fernandes G.W. and Cornelissen T. 2009. Ants on plants: a meta-analysis of the role of ants as plant biotic defenses. Oecologia 160: 537-549.

Rubin EM 2008 Genomics of cellulosic biofuels Nature 454:841-845

Ruiz-Lozano J. and Azcón R. 1995. Hyphal contribution to water uptake in mycorrhizal plants as affected by the fungal species and water status. Physiol Plantarum 95: 472-478.

Sabia E, Claps S, Morone G, Bruno A, Sepe L, Aleandri R 2015 Field inoculation of arbuscular mycorrhiza on maize (Zea mays L.) under low inputs: preliminary study on quantitative and qualitative aspects Italian Journal of Agronomy 10:607

Safir G., Boyer J. and Gerdemann J. 1971. Mycorrhizal enhancement of water transport in soybean. Science 172: 581-583.

Sanaullah M, Rumpel C, Charrier X, Chabbi A 2012 How does drought stress influence the decomposition of plant litter with contrasting quality in a grassland ecosystem? Plant and Soil 352:277-288

Sanderson MA, Adler PR, Boateng AA, Casler MD, Sarath G 2006 Switchgrass as a biofuels feedstock in the USA Canadian Journal of Plant Science 86:1315-1325

Sarath G, Mitchell RB, Sattler SE, Funnell D, Pedersen JF, Graybosch RA, Vogel KP 2008 Opportunities and roadblocks in utilizing forages and small grains for liquid fuels J Ind Microbiol Biotechnol 35:343-354

Sawers RJ, Gutjahr C, Paszkowski U 2008 Cereal mycorrhiza: an ancient symbiosis in modern agriculture Trends in Plant Science 13:93-97 
Scarlat N, Dallemand J-F 2011 Recent developments of biofuels/bioenergy sustainability certification: A global overview Energy Policy 39:1630-1646

Scarsbrook C (1965) Nitrogen availability Soil nitrogen:481-502

Scherm H (2004) Climate change: can we predict the impacts on plant pathology and pest management? Canadian Journal of Plant Pathology 26:267-273

Scheublin TR, Ridgway KP, Young JPW, Van Der Heijden MG (2004) Nonlegumes, legumes, and root nodules harbor different arbuscular mycorrhizal fungal communities Appl Environ Microbiol 70:6240-6246

Schouteden N., De Waele D., Panis B. and Vos C.M. 2015. Arbuscular mycorrhizal fungi for the biocontrol of plant-parasitic nematodes: a review of the mechanisms involved. Front Microbiol 6: 1280.

Schutzendubel A. and Polle A. 2002. Plant responses to abiotic stresses: heavy metalinduced oxidative stress and protection by mycorrhization. J Exp Bot 53: 13511365.

Schweiger R, Müller C 2015 Leaf metabolome in arbuscular mycorrhizal symbiosis Current opinion in plant biology 26:120-126

Secilia J, Bagyaraj D 1992 Selection of efficient vesicular-arbuscular mycorrhizal fungi for wetland rice (Oryza sativa L.) Biology and fertility of soils 13:108-111

Sendek A et al. (2019) Drought modulates interactions between arbuscular mycorrhizal fungal diversity and barley genotype diversity Scientific reports 9:1-15

Shibayama M., Takahashi W., Morinaga S. and Akiyama T. 1993. Canopy water deficit detection in paddy rice using a high resolution field spectroradiometer. Remote Sens Environ 45: 117-126.

Singh L.P., Gill S.S. and Tuteja N. 2011. Unraveling the role of fungal symbionts in plant abiotic stress tolerance. Plant signaling \& behavior 6: 175-191.

Smith FA, Smith SE 2013 How useful is the mutualism-parasitism continuum of arbuscular mycorrhizal functioning? Plant and Soil 363:7-18

Smith SE, Read DJ 2010 Mycorrhizal symbiosis. Academic press,

Somasekhar N, Prasad JS (2012) Plant-nematode interactions: consequences of climate change. In: Crop stress and its management: Perspectives and strategies. Springer, pp 547-564

Song Y, Chen D, Lu K, Sun Z, Zeng R 2015 Enhanced tomato disease resistance primed by arbuscular mycorrhizal fungus Frontiers in plant science 6:786

Staddon PL, Fitter AH, Graves JD 1999 Effect of elevated atmospheric CO2 on mycorrhizal colonization, external mycorrhizal hyphal production and phosphorus inflow in Plantago lanceolata and Trifolium repens in association with the 
arbuscular mycorrhizal fungus Glomus mosseae Global Change Biology 5:347358

Stone C. and Bacon P.E. 1994. Relationships among moisture stress, insect herbivory, foliar cineole content and the growth of river red gum Eucalyptus camaldulensis. J Appl Ecol: 604-612.

Stroup J., Sanderson M., Muir J., McFarland M. and Reed R. 2003. Comparison of growth and performance in upland and lowland switchgrass types to water and nitrogen stress. Bioresource Technol 86: 65-72.

Studer MH et al. 2011 Lignin content in natural Populus variants affects sugar release Proceedings of the National Academy of Sciences 108:6300-6305

Team R.C. 2015. R: A language and environment for statistical computing.

Team RC 2017 R: A language and environment for statistical com-puting R Foundation for Statistical Computing, Vienna, Austria URL https://www R-project org

Terzi R, Güler NS, Çalişkan N, Kadioğlu A 2013 Lignification response for rolled leaves of Ctenanthe setosa under long-term drought stress Turkish Journal of Biology 37:614-619

USDA N 2006 Plant Fact Sheet, Panicum virgatum (Switchgrass).

Van Soest P, Robertson J 1979 Systems of analysis for evaluating fibrous feeds. In: Standardization of analytical methodology for feeds: proceedings... IDRC, Ottawa, ON, CA,

Veresoglou SD, Menexes G, Rillig MC 2012 Do arbuscular mycorrhizal fungi affect the allometric partition of host plant biomass to shoots and roots? A meta-analysis of studies from 1990 to 2010 Mycorrhiza 22:227-235

Vierheilig H, Coughlan AP, Wyss U, Piché Y 1998 Ink and vinegar, a simple staining technique for arbuscular-mycorrhizal fungi Appl Environ Microbiol 64:50045007

Vierheilig H., Schweiger P. and Brundrett M. 2005. An overview of methods for the detection and observation of arbuscular mycorrhizal fungi in roots. Physiol Plantarum 125: 393-404.

Vincent C, Rowland D, Na C, Schaffer B 2017 A high-throughput method to quantify root hair area in digital images taken in situ Plant and Soil 412:61-80

Vincent D, Lapierre C, Pollet B, Cornic G, Negroni L, Zivy M 2005 Water deficits affect caffeate O-methyltransferase, lignification, and related enzymes in maize leaves. A proteomic investigation Plant Physiology 137:949-960

Vogel J 2008 Unique aspects of the grass cell wall Current opinion in plant biology 11:301-307

Vorwerk S, Somerville S, Somerville C 2004 The role of plant cell wall polysaccharide composition in disease resistance Trends in plant science 9:203-209 
Vos C., Claerhout S., Mkandawire R., Panis B., De Waele D. and Elsen A. 2012. Arbuscular mycorrhizal fungi reduce root-knot nematode penetration through altered root exudation of their host. Plant Soil 354: 335-345.

Vos C., Van Den Broucke D., Lombi F.M., De Waele D. and Elsen A. 2012. Mycorrhizainduced resistance in banana acts on nematode host location and penetration. Soil Biol Biochem 47: 60-66.

Whitham T. 1991. Plant responses to herbivory: the continuum from negative to positive and underlying physiological mechanisms. Plant-animal interactions: evolutionary ecology in tropical and temperate regions: 227-256.

Wilhite D.A. 2000. Drought as a natural hazard: concepts and definitions. Drought A Global Assessment 1:3-18

Willis A, Rodrigues B, Harris PJ 2013 The ecology of arbuscular mycorrhizal fungi Critical Reviews in Plant Sciences 32:1-20

Wilson G, Williamson M 2008 Topsin-M: the new benomyl for mycorrhizal-suppression experiments Mycologia 100:548-554

Wise M.J. and Abrahamson W.G. 2005. Beyond the compensatory continuum: environmental resource levels and plant tolerance of herbivory. Oikos 109: 417428 .

Wright S.F. and Upadhyaya A. 1998. A survey of soils for aggregate stability and glomalin, a glycoprotein produced by hyphae of arbuscular mycorrhizal fungi. Plant Soil198: 97-107.

Wu Q.-S. and Xia R.-X. 2006. Arbuscular mycorrhizal fungi influence growth, osmotic adjustment and photosynthesis of citrus under well-watered and water stress conditions. Journal of Plant Physiol 163: 417-425.

Wu Q-S, Srivastava AK, Zou Y-N 2013 AMF-induced tolerance to drought stress in citrus: a review Scientia Horticulturae 164:77-87

Wu Q-S, Xia R-X 2006 Arbuscular mycorrhizal fungi influence growth, osmotic adjustment and photosynthesis of citrus under well-watered and water stress conditions Journal of plant physiology 163:417-425

Xie F., Stewart Jr C.N., Taki F.A., He Q., Liu H. and Zhang B. 2014. High-throughput deep sequencing shows that micro RNA s play important roles in switchgrass responses to drought and salinity stress. Plant Biotechnol J 12: 354-366.

Yang J., Kloepper J.W. and Ryu C.-M. 2009. Rhizosphere bacteria help plants tolerate abiotic stress. Trends Plant Sci 14: 1-4.

Yang L, Wang C, Guo W, Li X, Lu M, Yu C 2006 Differential expression of cell wall related genes in the elongation zone of rice roots under water deficit Russian Journal of Plant Physiology 53:390-395 
Yao Q, Wang L, Zhu H, Chen J 2009 Effect of arbuscular mycorrhizal fungal inoculation on root system architecture of trifoliate orange (Poncirus trifoliata L. Raf.) seedlings Scientia Horticulturae 121:458-461

Young T. 1954. An incubation method for collecting migratory endoparasitic nematodes. Plant Dis Rep 38: 794-795.

Zeng Y, Zhao S, Yang S, Ding S-Y 2014 Lignin plays a negative role in the biochemical process for producing lignocellulosic biofuels Current opinion in biotechnology $27: 38-45$

Zhang H., Schonhof I., Krumbein A., Gutezeit B., Li L., Stützel H. and Schreiner M. 2008. Water supply and growing season influence glucosinolate concentration and composition in turnip root (Brassica rapa ssp. rapifera L.). J Plant Nutr and Soil Sci 171: 255-265.

Zhang R-Q, Zhu H-H, Zhao H-Q, Yao Q 2013 Arbuscular mycorrhizal fungal inoculation increases phenolic synthesis in clover roots via hydrogen peroxide, salicylic acid and nitric oxide signaling pathways Journal of Plant Physiology 170:74-79

Zou Y-N, Wang P, Liu C-Y, Ni Q-D, Zhang D-J, Wu Q-S 2017 Mycorrhizal trifoliate orange has greater root adaptation of morphology and phytohormones in response to drought stress Scientific reports 7:1-10

Zwiazek JJ 1991 Cell wall changes in white spruce (Picea glauca) needles subjected to repeated drought stress Physiologia Plantarum 82:513-518 


\section{APPENDIX I}

\section{SUPPLEMENTAL DATA FROM CHAPTER I}

\section{Appendix I Figure 14: KBS LTER map}

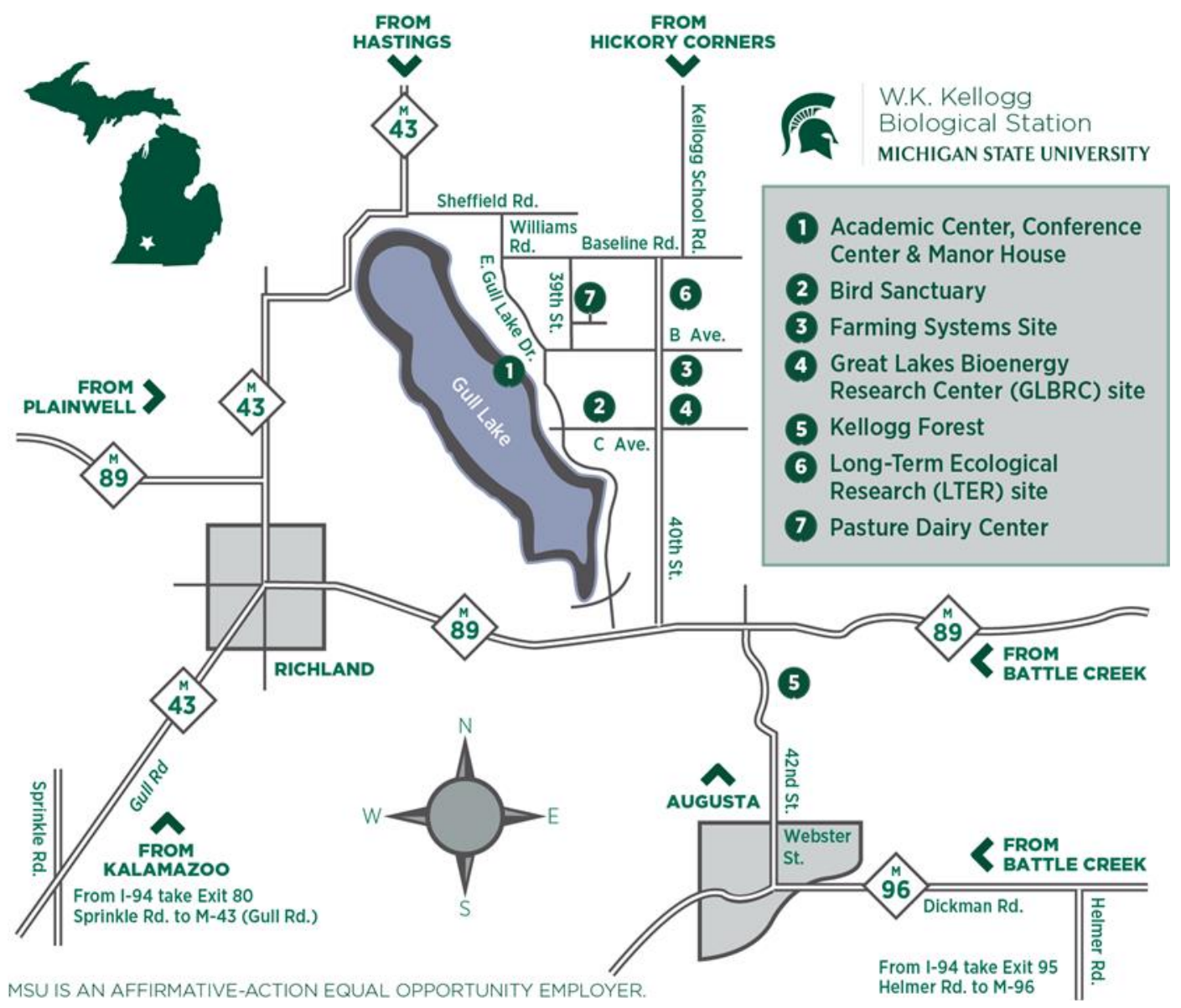




\section{Appendix I Figure 15: KBS LTER Cellulosic Biofuel Diversity Experiment plot layout}

KBS LTER Cellulosic Biofuel Diversity Experiment
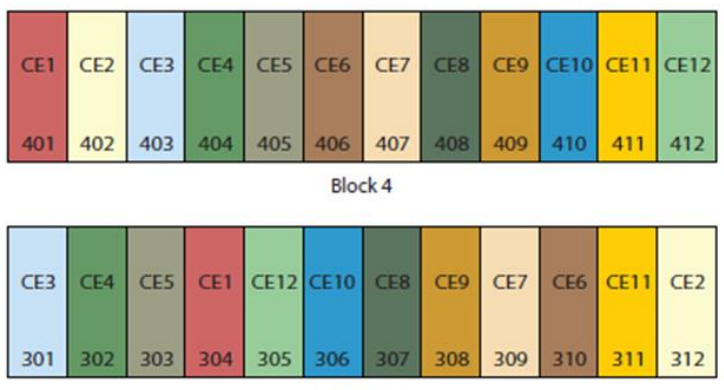

Block 3
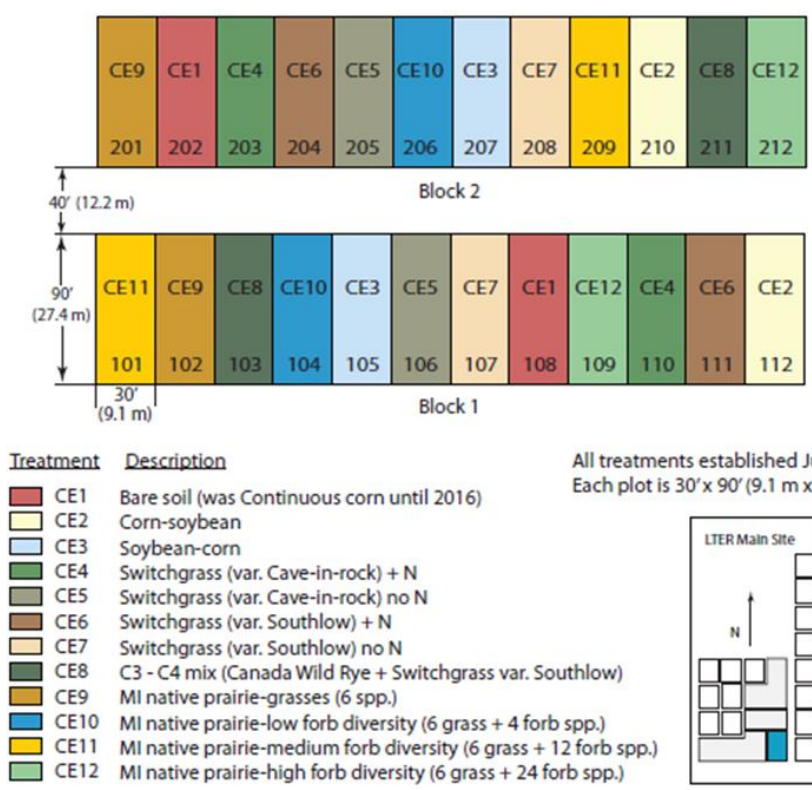

All treatments established June 2008

$\begin{array}{ll}\square \text { CE1 } & \text { Bare soil (was Continuous corn until 2016) } \\ \text { CE2 } & \text { Corn-soybean } \\ \text { CE3 } & \text { Soybean-corn } \\ \text { CE4 } & \text { Switchgrass (var. Cave-in-rock) }+\mathrm{N} \\ \text { CE5 } & \text { Switchgrass (var. Cave-in-rock) no } \mathrm{N} \\ \text { CE6 } & \text { Switchgrass (var. Southlow) }+\mathrm{N} \\ \text { CE7 } & \text { Switchgrass (var. Southlow) no } \mathrm{N} \\ \text { CE8 } & \text { C3 - C4 mix (Canada Wild Rye }+ \text { Switch } \\ \text { CE9 } & \text { MI native prairie-grasses (6 var. Southlow) } \\ \text { CE10 } & \text { MI native prairie-low forb diversity (6 grass }+4 \text { forb spp.) } \\ \text { CE11 } & \text { MI native prairie-medium forb diversity (6 grass + 12 forb spp.) } \\ \text { CE12 } & \text { MI native prairie-high forb diversity (6 grass }+24 \text { forb spp.) }\end{array}$

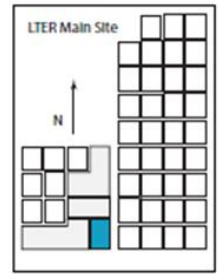

Revised May 2017 


\title{
CURRICULUM VITAE
}

\author{
Binod Basyal \\ Department of Biology, University of Louisville \\ 139 Life Science Bldg. Louisville, KY, 40292 \\ Office: 502-852-5220, Cell: 502-533-6295 \\ b0basy01@louisville.edu
}

\section{Education}

2015-present Ph.D. Biology (ecology and evolutionary biology concentration), Department of Biology, University of Louisville (UofL), Louisville, KY, PI: Dr. Sarah Emery Title: Aboveground-belowground interactions: Roles of soil biotic and abiotic factors on switchgrass's growth, defense against herbivory and cell wall chemistry

2008-2012 B.Sc. in Agriculture, Institute of Agriculture and Animal Science, Tribhuvan University, Chitwan, Nepal, (Elective Course: Plant Breeding and Biotechnology)

\section{Professional Appointments}

2016-2019 Graduate Teaching Assistant, University of Louisville, KY

Course taught: Principles of Quantitative Biology Laboratory (BIOL 244)

2014-2015 Agriculture Extension Officer, Practical Action Nepal, Pilot Project for Climate Resilience (PPCR)

2008 Primary Level Science Teacher, Dhawalagiri Boarding School, Kaski, Nepal

\section{Manuscripts}

2019

B. Basyal and S.M. Emery. Effects of arbuscular mycorrhizal fungi and drought on two cultivars of Panicum virgatum under root herbivory by Pratelynchus penetrans. (In revision, Plant Ecology)

2019 B. Basyal and S.M. Emery. Interaction with belowground biotic and abiotic factors affect the biomass quality and quantity of a candidate biofuel crop. (In prep to submit to Biomass and Bioenergy) 
B. Basyal and S.M. Emery. Arbuscular mycorrhizal fungi benefit switchgrass growth and alters tissue chemistry under extreme drought. (In prep to submit to Mycorrhiza)

\section{Scholarships and Fellowships}

2019 Doctoral Dissertation Completion Fellowship (\$12000)

2015-2019 University Fellowship, University of Louisville $(\$ 48,326)$

2008-2012 Dean's Merit List full scholarship, Tribhuvan University (\$6000)

2006-2008 SOS Hermann Gmeiner Scholarship (\$4000)

\section{Grants and Awards}

2020

2019

2019

2019

2018

2018

2018

2018

2018

2017

2017

2016
Dean's Citation

Parkinson's Award from Soil Ecology Society $(\$ 450)$

UofL Graduate Students Council travel award (\$350)

UofL Biology Graduate Students CFP research award (\$1000)

Soil Ecology Section of Ecological Society of America (ESA) Student Travel Award (\$500)

1970s UofL Biology Grad Student Cohort Endowment (E2091) travel grant $(\$ 140)$

UofL Graduate Students Council travel grant (\$350)

UofL Biology Graduate Student travel award (\$125)

The Beechmont Garden Club Award (\$1000)

Marcia Athey and Botany grant, Kentucky Academy of Science (\$2400)

UofL Graduate Student Council research grant (\$490)

UofL Graduate Network of Arts and Sciences research grant (\$100)

\section{Presentations}

2019

2019

2019

2019
Basyal B and Emery SM. "Arbuscular mycorrhizal fungi benefit switchgrass growth and root architecture under extreme drought" Kentucky Academy of Science, Berea, KY (Talk)

Basyal B and Emery SM. "Arbuscular mycorrhizal fungi benefit switchgrass growth and root architecture under extreme drought" Long Term Ecological Research All Scientist Meeting, Hickory Corners, MI (Poster)

Basyal B and Emery SM. "Interaction with belowground biotic and abiotic factors affect the biomass quality and quantity of a candidate biofuel crop" Ecological Society of America Meeting, Louisville, KY (Talk)

Basyal B and Emery SM. "Interaction with belowground biotic and abiotic factors affect the biomass quality and quantity of a candidate biofuel crop" Soil Ecology Society Meeting, Toledo OH, (Talk) 
Basyal B and Emery SM. "Aboveground-belowground interactions under biotic and abiotic stresses" UofL Graduate Student Awards Day (Talk)

2018 Basyal B and Emery SM. "Do arbuscular mycorrhizal fungi (AMF) provide any growth benefits and herbivory resistance against plant parasitic nematodes (PPN) in Panicum virgatum?" Ecological Society of America Meeting, New Orleans LA, (Poster)

2018 Basyal B and Emery SM. "Drought, plant and friendly fungi" 3MT Thesis Competition, UofL (Talk)

$2018 \quad$ Basyal B and Emery SM. "Do mycorrhizae help plants in drought and herbivory?" Midwest Ecology and Evolution Conference, Hickory Corners MI, (Talk)

2018 Basyal B and Emery SM. "Do mycorrhizae help plants in drought and herbivory?" GRADtalks Brown Bag Series, UofL, (Talk)

\title{
Teaching Experience (non GTA)
}

2019

Designed lab activity for non-major's environmental biology course, Title: Effects of different land uses on soil nematode abundance

2016 Basyal B. "Conservation in Nepal" Advanced Conservation Biology Class, Biology, UofL, (A guest lecture)

\section{Mentoring Experience}

2020

2018-2019

2018

2017
Lindsey Barnes (Undergrad), Effects of aboveground herbivory on AMF recruitment and belowground interactions with plant parasitic nematodes

Kaitlyn Goode (Undergrad), AMF-Plant mutualism along drought intensity gradient

Heather Griffith and Sarah Benton (Undergrads), Effects of belowground organisms on plant cell wall quality and quantity

Brandon Nguyen (Undergrad), Effects of AMF and drought on plant growth and belowground herbivory

\section{Workshops, trainings and non-credit courses}

2019

2019

2019

2019

2018

\author{
Essential skills for Next Generation Sequencing and Data Analysis \\ Workshop, Kentucky Biomedical Research Infrastructure Network \\ Graduate Teaching Academy's mentoring workshop, UofL \\ Soil Ecology Data Workshop, Soil Ecology Society, Toledo OH \\ Applied Statistics course (UofL) \\ Multivariate Statistics course (UofL)
}




\section{Software proficiency}

$\mathrm{R}$ and $\mathrm{R}$ studio, Arc GIS, WinRhizo (Image analysis), Image $\mathrm{J}$ (Image analysis), BLAST (Sequence Alignment), SNAP and MAKER (Gene prediction), QIIME 2 (Metagenomic Data analysis)

\section{Professional Services}

$2020 \quad$ Volunteer in UofL Climate Science Day, KY

2020 Grant proposal reviewer at Kentucky Academy of Science, KY

2019 Student volunteer and session presider at Ecological Society of America Meeting, KY

2019 Kentucky Science Center Speed Mentoring Guide, KY

2018 Student volunteer and session presider at Ecological Society of America Meeting, LA

2018 Volunteer in Global Climate Change Education Project's Louisville Day of Science about Climate Change, KY

2018 Judge at Manual School Regional Science Fair, KY

2016 Bioblitz (A field survey of wildlife in Lincoln Boyhood National Memorial Park, IN)

2010-2011 Vice-secretary in Nepal Youth Red Cross Circle, Tribhuvan University, Nepal

2005-2006 President of Junior Red Cross Circle, Kanchenjunga Academic CenterSecondary School, Nepal

\section{Professional memberships}

2018-Present Ecological Society of America member

2019-Present Soil Ecology Society member

2017-Present Kentucky Academy of Science member

\section{References}

Dr. Sarah M. Emery (Advisor)

Professor and Director of Graduate Studies

Department of Biology, UofL

sarah.emery@louisville.edu

Dr. Steve Yanoviak (Committee member)

Professor

Department of Biology, UofL

steve.yanoviak@louisville.edu 
Dr. Karen Stahlheber (Committee member)

Assistant Professor

Department of Biology

University of Wisconsin-Green Bay

stahlhek@uwgb.edu

Date: $03 / 15 / 20$ 